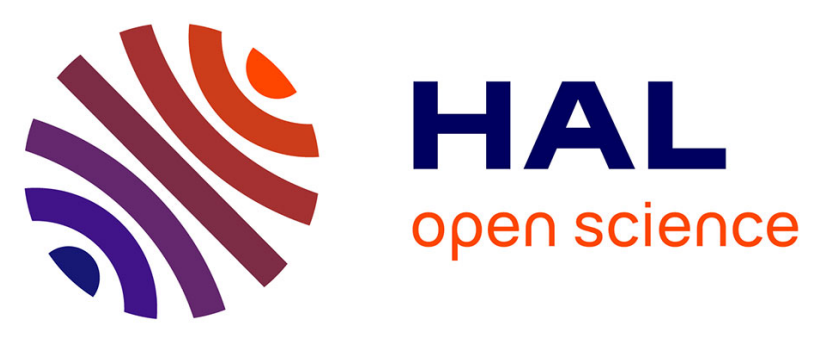

\title{
Energy, exergy, economic, exergoenvironmental, and environmental analyses of a multigeneration system to produce electricity, cooling, potable water, hydrogen and sodium-hypochlorite
}

\author{
M. A. Ehyaei, Simin Baloochzadeh, A. Ahmadi, Stéphane Abanades
}

\section{To cite this version:}

M. A. Ehyaei, Simin Baloochzadeh, A. Ahmadi, Stéphane Abanades. Energy, exergy, economic, exergoenvironmental, and environmental analyses of a multigeneration system to produce electricity, cooling, potable water, hydrogen and sodium-hypochlorite. Desalination, 2021, 501, pp.114902. 10.1016/j.desal.2020.114902 . hal-03221045

\section{HAL Id: hal-03221045 \\ https://hal.science/hal-03221045}

Submitted on 7 May 2021

HAL is a multi-disciplinary open access archive for the deposit and dissemination of scientific research documents, whether they are published or not. The documents may come from teaching and research institutions in France or abroad, or from public or private research centers.
L'archive ouverte pluridisciplinaire $\mathbf{H A L}$, est destinée au dépôt et à la diffusion de documents scientifiques de niveau recherche, publiés ou non, émanant des établissements d'enseignement et de recherche français ou étrangers, des laboratoires publics ou privés. 


\title{
Energy, Exergy, Economic, Exergoenvironmental, and Environmental analyses of a Multigeneration System to Produce Electricity, Cooling, Potable Water, Hydrogen and Sodium-Hypochlorite
}

\author{
M. A. Ehyaei ${ }^{1 *}$, Simin Baloochzadeh ${ }^{2 *}$, A. Ahmadi ${ }^{3}$, Stéphane Abanades $^{4}$ \\ ${ }^{1}$ Department of Mechanical Engineering, Pardis Branch, Islamic Azad University, Pardis New City \\ 1468995513, Iran; \\ ${ }^{2}$ Faculty of Technology, University of Sunderland, Sunderland, United Kingdom \\ ${ }^{3}$ Iran University of Science and Technology, School of New Technologies, Department of Energy Systems \\ Engineering, Iran \\ ${ }^{4}$ Processes, Materials, and Solar Energy Laboratory, PROMES-CNRS, 7 Rue du Four Solaire, 66120, Font- \\ Romeu, France \\ Corresponding Author: aliehyaei@yahoo.com , mailto:bg17pm@student.sunderland.ac.uk
}

\begin{abstract}
One of the necessities of human beings in this century is the potable water supply. This supply has more environmental benefits if the potable water is supplied by renewable energy resources. In this paper, a combination of combined cooling and power system (Goswami cycle), with the reverse osmosis and sodium hypochlorite plant powered by geothermal energy resources is proposed. The products of this system are electrical and cooling energy, potable water, hydrogen and salt. To investigate all of the system aspects, energy, exergy, economic, exergoenvironmental, and environmental analyses are performed. In environmental analysis, the social costs of air pollution are considered. It means that for the same amount of system electrical power produced by non-renewable energy resource power generation systems, the produced air pollution gases and their costs considering the social cost of air pollution are quantified. In this regard, four scenarios are defined. Results show this multi-generation system produces $1.751 \mathrm{GJ} /$ year electrical energy, $1.04 \mathrm{GJ} /$ year cooling energy, $18106.8 \mathrm{~m}^{3} /$ year potable water, $7.396 \mathrm{Ton} /$ year hydrogen, and 3.838 Ton/year salt throughout a year. The system energy and exergy efficiencies are equal to $12.25 \%$, and $19.6 \%$. The payback period time of this system is equal to 2.7 years.
\end{abstract}

Keywords: Goswami Cycle; Reverse Osmosis; Salt; Exergy; Economic; Exergoenvironmental

\section{Introduction}

Water scarcity is one of the greatest dangers threatening people [1]. This shortage was considered high risk by the World Economic Forum [2]. Around four billion people experience potable water shortage during at least one month of a year and five hundred million experience this all the time year along [3].

Around $0.014 \%$ of global amount of water existing on Earth is potable water. The remaining part is brine water or non-accessible. However, the amount of potable water is sufficient, but regarding unequal distribution, some regions such as the middle east suffer from potable water shortage [4]. 
In addition to the non-equal distribution of potable water, several factors affect the water shortage, such as world population growth, living standard, method of water consumption, agriculture, climate change, and industrial impacts [5].

Thus, supplying potable water is essential for humanity and this can be achieved via desalination. The desalination processes are divided into four main groups: thermal desalination processes [69] (multi-stage flash distillation (MSF), multi-effect distillation (MED), vapor-compression evaporation (VC)); membrane processes [10] (reverse osmosis (RO), electrodialysis (ED), membrane distillation (MD)); freezing [11]; and ion exchange - solvent process [12, 13]. The strengths and weaknesses of desalination methods are depicted in Table 1.

Table 1. Strengths and weaknesses of desalination techniques

\begin{tabular}{|c|c|c|c|c|}
\hline No. & Techniques & Strength & Weakness & Ref \\
\hline \multicolumn{5}{|c|}{ Thermal desalination processes } \\
\hline 1 & MSF & $\begin{array}{ll}- & \text { Relatively simple } \\
\text { - } & \text { Low number moving components } \\
\text { - } & \text { High purification } \\
& \text { quality } \\
\text { - } & \text { The possibility to add more stage } \\
& \text { to performance improvement }\end{array}$ & - $\quad$ Tube clogging & $\begin{array}{l}{[9,11,} \\
14,15]\end{array}$ \\
\hline 2 & MED & $\begin{array}{ll}\text { - } & \text { Less tube corrosion in comparison } \\
\text { with MSF } \\
\text { - } \\
\text { Less sensitive to feed water } \\
\text { quality } \\
\text { - } \quad \text { Lower power consumption in } \\
\text { comparison with MSF } \\
\text { - } \quad \text { Higher efficiency than MSF }\end{array}$ & - $\quad$ Tube clogging & {$[9,15]$} \\
\hline 3 & vC & $\begin{array}{ll}- & \text { Reliability and simplicity } \\
\text { - } & \text { Low operating temperature than } \\
& \text { MED and MSF } \\
\text { - } & \text { Lower tube corrosion } \\
\end{array}$ & $\begin{array}{l}\text { The extra cost for } \\
\text { compressor } \\
\text { The larger size of the heat } \\
\text { exchanger }\end{array}$ & {$[16,17]$} \\
\hline \multicolumn{5}{|c|}{$\begin{array}{l}\text { Membrane processes } \\
\end{array}$} \\
\hline 4 & RO & $\begin{array}{ll}- & \text { Less corrosion } \\
- & \text { Lower prices } \\
- & \text { Usage of turbine recovery } \\
\end{array}$ & $\begin{array}{l}\text { Clogging of membrane } \\
\text { The requirement of a large } \\
\text { quantity of water }\end{array}$ & {$[9,15]$} \\
\hline 5 & ED & $\begin{array}{l}\text { - High recovery } \\
\text { The proportion of energy } \\
\text { requirement to salt removing }\end{array}$ & $\begin{array}{l}\text { - } \begin{array}{l}\text { Non-suitable for water with } \\
\text { particles less than } 0.4 \mathrm{~g} / \mathrm{L} \\
\text { Non-affordable for water } \\
\text { with particles higher than } 30 \\
\mathrm{~g} / \mathrm{L} \\
\text { Low chemical usage for pre- } \\
\text { treatment }\end{array} \\
\end{array}$ & {$[9,18]$} \\
\hline 6 & MD & $\begin{array}{ll}\text { - } & \text { Simplicity } \\
\text { - } & \text { Less operating temperature }\end{array}$ & $\begin{array}{l}\text { - } \quad \text { More space requirement } \\
\text { Same energy usage with } \\
\text { MSF and MED } \\
\text { Needs for feed water with } \\
\text { no organic pollutant }\end{array}$ & {$[9,15]$} \\
\hline \multicolumn{5}{|c|}{ Freezing } \\
\hline
\end{tabular}




\begin{tabular}{|c|c|c|c|c|}
\hline 7 & Freezing & $\begin{array}{l}\text { - } \quad \text { Lower energy requirement } \\
\text { - } \quad \text { Low corrosion } \\
\text { - Very pure potable water }\end{array}$ & $\begin{array}{l}\text { - Hardly moving of ice and } \\
\text { water mixture }\end{array}$ & {$[9,19]$} \\
\hline \multicolumn{5}{|c|}{ Ion exchange - the solvent process } \\
\hline 8 & $\begin{array}{c}\text { Ion exchange - the solvent } \\
\text { process }\end{array}$ & $\begin{array}{ll}- & \text { Low cost } \\
\text { - } & \text { Simplicity } \\
\text { - } & \text { Operation easily }\end{array}$ & $\begin{array}{ll}\text { - } & \text { Long production cycle } \\
\text { - } & \text { Poor quality product } \\
\text { - } & \text { Large PH changes }\end{array}$ & {$[20]$} \\
\hline
\end{tabular}

Based on a survey carried out by Shahzad et al. [21], the potable water demand will increase up to 60 billion $\mathrm{m}^{3}$ by 2050 . This huge amount of water production can be achieved with different types of desalination systems so that the total energy consumption of desalination systems reaches 75.2 TWh per year. Moreover, it was recommended to improve the thermodynamic efficiency of the desalination systems from $10 \%$ to $25 \%$, develop high flux membrane material for RO system, and design high-efficiency hybrid MED/MSF desalination systems.

It is preferable that the thermal and electrical energy needs of the various kinds of desalination system can be met by renewable energy resources due to elimination of pollution during operation time and depletion of non-renewable energy resources such as gas, oil, coal, etc. [22].

Among renewable energy resources, geothermal energy has a high potential for use in industrial and residential applications based on the mass flow rate, temperature, and pressure of geothermal fluid [23]. These applications are divided into many categories such as electrical [24], hydrogen [25], heating and cooling [26], and freshwater productions [27], as well as, cogeneration/multigeneration systems which have two or more products [28].

Hybrid cogeneration of the solar and geothermal based system with ammonia fuel cell was examined for electricity, hydrogen, cooling, and fresh-water production. By this configuration, $42.3 \%$ and $21.3 \%$ energy and exergy efficiency were achieved in this hybrid system. In addition, the effects of different parameters on the system performance were studied by parametric analyses of the total system and associated subsystems [29].

A modified Kalina cycle was integrated with a reverse osmosis system to provide heating, cooling and power, and potable water. In this investigation, energy and exergy analyses were examined to evaluate its performance. The results of this investigation showed that the system can generate $46.77 \mathrm{~kW}$ electricity, $451 \mathrm{~kW}$ heating, $52 \mathrm{~kW}$ cooling, and $0.79 \mathrm{~kg} / \mathrm{s}$ potable water. Also, it was 
concluded that the thermodynamic properties of the steam cycle were dominant because these parameters can affect both the steam cycle and the Kalina cycle [30].

Integration of a photovoltaic system and geothermal source was examined to provide $840 \mathrm{~kW}$ electricity, heating, $5.295 \mathrm{~kg} / \mathrm{s}$ biogas, and $2.773 \mathrm{~kg} / \mathrm{s}$ desalinated water. The mixed fluid cascade cycle was employed for methane liquefaction. Its specific power consumption was reduced to $0.1888 \mathrm{kWh} / \mathrm{kg}$ LNG by application of an absorption refrigeration system. The energy and exergy efficiencies of this integrated system were $73.2 \%$ and $76.8 \%$, respectively [31].

In a study carried out by Behnam et al. [32], exergy and thermo-economic analysis of a novel lowtemperature geothermal heat resource for electricity, hot water, and fresh-water production were examined. Moreover, the sensitivity of decision parameters on the performance of this system was also analyzed. The results of this study showed that by using $100^{\circ} \mathrm{C}$ geothermal water, this system was able to produce $0.662 \mathrm{~kg} / \mathrm{s}$ freshwater, $161.5 \mathrm{~kW}$ power, and $246 \mathrm{~kW}$ heat load.

A multi-effect distillation (MED) desalination plant of $9000 \mathrm{~m}^{3} /$ day with solar (parabolic trough collectors) and geothermal energy resources was examined in Spain. The theoretical results of this study revealed that this amount of fresh water was obtained during $76 \%$ of the annual time with both solar and geothermal resources (at $490 \mathrm{~m}$ depth) and a hot water temperature of $41.8{ }^{\circ} \mathrm{C}$. However, the results of this study revealed by considering a gradient temperature of $8.87{ }^{\circ} \mathrm{C}$ per $100 \mathrm{~m}$ depth, just geothermal energy at depth of $790 \mathrm{~m}$ was enough to obtain working temperature of the desalination plant at $70{ }^{\circ} \mathrm{C}[33]$.

The application of a humidification-dehumidification (HDH) unit in a flash-binary geothermal heat source at $170 \mathrm{~m}$ was examined in a new tri-generation system for power, cooling, and freshwater production. The results of this study showed that the increment of the steam turbine output power, overall cooling load, gain-output-ratio (TGOR), and exergy efficiency of this system was around $77.1 \%, 87 \%, 8.2 \%$, and $46.4 \%$, respectively. The overall exergy destruction of this trigeneration system at the base mode was $946.7 \mathrm{~kW}$. The recovery heat exchanger was recognized as the most destructive component in the base mode with exergy destruction of $308.5 \mathrm{~kW}$ [34].

An integrated system containing parabolic trough solar collectors and wind turbines was examined by Makkah et al. [35]. The benefits of a membrane-thermal desalination system to produce power and freshwater were pointed out. This proposed cogeneration system was employed for providing 
electrical power and fresh water in Iran by three types of desalination system consisting of the Reverse Osmosis (RO), Multi-effect distillation (MED), and Thermal Vapor Compression (TVC). The obtained results from exergy analysis demonstrated that the exergy destruction of the solar collectors and wind turbines contributed by $39.5 \%$ and $22.2 \%$, respectively. The results of multiobjective particle swarm optimization revealed that the exergy efficiency and the cost of freshwater production reach $26.2 \%$ and $3.08 \mathrm{US} \$ / \mathrm{m}^{3}$. The environmental assessments showed that this hybrid system avoids 52164 tons of $\mathrm{CO}_{2}$ emission per year.

A solar organic Rankine cycle (ORC) was employed for power generation and freshwater production by reverse osmosis (RO) desalination units in a power scale less than $500 \mathrm{~kW}$. The performance of the ORC/RO desalination set-up was improved by using a cascade ORC/ORC system. Salinity-gradient solar pond (SGSP) was used instead of the conventional solar collector. These results showed that the ORC/ORC/RO system had the highest performance along with the lowest SUCP (sum unit cost of product) and total exergy destruction. Furthermore, the most economical month $\mathrm{f}$ was June due to the low value of SUCP $(72.42 \$ / \mathrm{kWh})$ since more freshwater was produced in this month [36].

Thermodynamic and thermo-economic performances of a hybrid solar and biomass power plant producing electricity, freshwater, and domestic hot water requirements for a 40 households' community were studied by Mouaky et al [37]. The considered community was located in a semiarid region in Morocco characterized by a good solar potential of $2239 \mathrm{kWh} / \mathrm{m}^{2} / \mathrm{y}$ and by the presence of brackish groundwater. In parabolic solar collectors and boilers, olive waste residues as feedstock were applied as a working fluid to run a $46 \mathrm{~kW}$ ORC and RO unit. The results showed that this proposed system was able to meet the community's requirements with an annual biomass consumption of 235 tons and a solar share of $11.4 \%$. Moreover, this investigation showed that the monthly plant's overall energy efficiency was in a range between 11.3 and $16.3 \%$, while its corresponding exergy efficiency was between 5.3 and $6.0 \%$.

Application of a solar dish collector integrating phase change material storage was used for providing thermal energy of a steam power plant with a capacity of $1063 \mathrm{MW}$. The phase-change material was applied during the night and in the absence of solar thermal sources. In order to prevent heat losses in the condenser, a large part of the dissipated heat was provided to a multi- 
effect desalination system. The desalination system produced $8321 \mathrm{~kg} / \mathrm{s}$ of freshwater by utilizing $2571 \mathrm{MW}$ of waste heat from the steam power plant. The total electrical efficiency of $28.84 \%$ and thermal efficiency of $97.2 \%$ were obtained for this system [38].

A plant consisting of photovoltaic panels, and supplying a RO unit for freshwater production was examined by Calise et al. [39]. The developed system was extremely profitable: the achieved payback period was about 1.3 years, mainly due to the high capital cost of freshwater in the reference scenario. Remarkable water-saving equivalent to $80 \%$ was obtained. For the selected case study, the sensitivity analyses suggested to adopt a solar field area equal to $6,436 \mathrm{~m}^{2}$. The economic consideration revealed low pay-back periods for specific costs of the water higher than $7 € / \mathrm{m}^{3}$.

Design and economic evaluation of solar-powered hybrid multi-effect and reverse osmosis system for seawater desalination were conducted by Filippini et al. [40]. In this study, the possibility of coupling the desalination plant with a photovoltaic (PV) solar farm was investigated to generate electricity at a low cost and in a sustainable way. Data about four locations, namely Isola di Pantelleria (IT), Las Palmas (ES), Abu Dhabi (UAE), and Perth (AUS), have been used to economically test the feasibility of installing the proposed plant, and especially the PV solar farm.

In a research conducted by Sezer et al. [41], the development and performance assessment of new integrated solar, wind, and osmotic power system for multi-generation, based on thermodynamic principles were examined. The results revealed that the overall obtained energy and exergy efficiencies were $73.3 \%$ and $30.6 \%$, respectively. The obtained results showed that this system was able to generate $51.6 \mathrm{MW}$ electrical power, $40.2 \mathrm{MW}$ refrigeration load, $559 \mathrm{~kg} / \mathrm{h}$ hydrogen, and $403.2 \mathrm{~L} / \mathrm{s}$ freshwater.

An integrated solar-driven membrane distillation system for water purification and energy generation was used by $\mathrm{Li}$ et al. [42]. It was found that a system with a solar absorbing area of $1.6 \mathrm{~m}^{2}$ coupled with $\sim 0.2 \mathrm{~m}^{2}$ of membranes can produce $\sim 4 \mathrm{~L}$ of drinkable water and $\sim 4.5 \mathrm{kWh}$ of heat energy (at $45^{\circ} \mathrm{C}$ ) per day (with an average daily solar exposure of $4 \mathrm{kWh} / \mathrm{m}^{2}$ ). The economic consideration of this study indicated that this system had a payback time of $\sim 4$ years.

The summary of previous studies is reported in Table 2.

Table 2. Various researches about the multi/cogeneration systems 


\begin{tabular}{|c|c|c|c|c|c|c|c|c|}
\hline No. & Energy resource & Components & Products & Analysis & $\begin{array}{l}\text { Energy } \\
\text { efficiency } \\
(\% 0\end{array}$ & $\begin{array}{c}\text { Exergy } \\
\text { efficiency } \\
(\%)\end{array}$ & $\begin{array}{l}\text { Cost of } \\
\text { products }\end{array}$ & Ref \\
\hline 1 & Solar/Geothermal & RO;PEMFC;ASR;AFC;HSR & $\begin{array}{l}\text { Electricity, } \\
\text { Freshwater, } \\
\text { Hydrogen, and } \\
\text { Cooling }\end{array}$ & Energy/Exergy & 42.3 & 21.3 & - & [29] \\
\hline 2 & Geothermal & $\mathrm{KC}, \mathrm{RO}$ & $\begin{array}{c}\text { Electricity, Heating, } \\
\text { Cooling, and } \\
\text { Freshwater }\end{array}$ & Energy/Exergy & - & 38.1 & - & {$[30]$} \\
\hline 3 & Solar/Geothermal & $\begin{array}{c}\text { Biogas system, MED, ORC; } \\
\text { PV }\end{array}$ & $\begin{array}{l}\text { Bio-liquefied natural } \\
\text { gas; Freshwater, } \\
\text { Electricity }\end{array}$ & Energy/Exergy & 73.2 & 76.8 & - & [31] \\
\hline 4 & Geothermal & ORC; ASR; SSE & $\begin{array}{l}\text { Electricity, Hot and } \\
\text { Fresh water }\end{array}$ & $\begin{array}{l}\text { Energy/Exergy/ } \\
\text { Thermoeconomic }\end{array}$ & 34 & 43 & $\begin{array}{c}\mathrm{LCOE}=0.04 \\
\$ / \mathrm{kWh} \\
\mathrm{LCOW}=29.4 \\
\$ / \mathrm{m}^{3} \\
\end{array}$ & {$[32]$} \\
\hline 5 & Solar/Geothermal & PTC; MED & Freshwater & Feasibility study & - & - & - & [33] \\
\hline 6 & Geothermal & FGPP; HDH & Electriciy/Cooling & Energy/Exergy & 46.4 & $\begin{array}{l}\text { TGOR= } \\
0.9275\end{array}$ & - & [34] \\
\hline 7 & Solar/Geothermal & MED; PTC; ORC & $\begin{array}{l}\text { Electricity; Cooling; } \\
\text { Heating; Freshwater; } \\
\text { Absorption Chiller }\end{array}$ & Exergy/Exergoeconomic & - & 63 & $\begin{array}{c}\text { Electricity } \\
\text { exergoeconomic } \\
\text { cost }=0.1475- \\
0.1722 € / \mathrm{kW} \mathrm{h} \\
\text { Chilled water } \\
\text { exergoeconomic } \\
\text { cost }=0.1863- \\
0.1888 € / \mathrm{kW} \\
\text { hex } \\
\text { Cooling water } \\
\text { exergoeconomic } \\
\text { cost }=0.01612- \\
0.01702 € / \mathrm{kW} \\
\text { hex } \\
\text { Freshwater } \\
\text { exergoeconomic } \\
\text { cost }=0.5695- \\
0.6023 € / \mathrm{kW} \\
\text { hex. }\end{array}$ & [34] \\
\hline 8 & Solar/Wind & $\begin{array}{c}\text { PTC; Wind turbine; MED; } \\
\text { RO }\end{array}$ & $\begin{array}{c}\text { Electricity/Fresh } \\
\text { water }\end{array}$ & $\begin{array}{l}\text { Energy/ Exergy/ } \\
\text { Exergoeconomic }\end{array}$ & - & 26.2 & $\begin{array}{c}\text { Fresh water } \\
\text { cost }=3.08 \$ / \mathrm{m}^{3}\end{array}$ & [35] \\
\hline 9 & Solar & Solar Pond; KC; ORC; RO & Electricity/Freshwater & $\begin{array}{l}\text { Thermodynamic/ } \\
\text { Thermoeconomic }\end{array}$ & - & 18 & $\begin{array}{c}\text { SUCP }=101.7 \\
\$ / \mathrm{kWh}\end{array}$ & [36] \\
\hline 10 & Solar/Biomass & & $\begin{array}{c}\text { Electricity/ } \\
\text { Freshwater/, domestic } \\
\text { hot water (DHW) }\end{array}$ & $\begin{array}{l}\text { Thermodynamic/ } \\
\text { Thermoeconomic }\end{array}$ & $\begin{array}{l}11.3- \\
16.3\end{array}$ & $5.3-6$ & $\begin{array}{l}\text { Electricity cost= } \\
0.231 € / \mathrm{kW} \\
\text { Fresh water } \\
\text { cost }=0.86 € / \mathrm{m}^{3} \\
\text { DHW cost= } \\
0.047 € / \mathrm{kW}\end{array}$ & [37] \\
\hline 11 & Solar & SD; PCM; SC; MED & $\begin{array}{l}\text { Electricity; } \\
\text { Freshwater }\end{array}$ & Energy/ Exergy & 28.8 & 52.2 & - & [38] \\
\hline 12 & Solar & PV; RO & $\begin{array}{l}\text { Electricity; } \\
\text { Freshwater }\end{array}$ & Economic & - & - & $\mathrm{PP}=1.3$ years & [39] \\
\hline 13 & Solar & PV; MED; RO & $\begin{array}{l}\text { Electricity; Fresh } \\
\text { water }\end{array}$ & Economic & - & - & $\begin{array}{c}\text { Electricity cost= } \\
0.1 € / \mathrm{kWh} \\
\text { Fresh water } \\
\text { cost }=0.59 € / \mathrm{m}^{3}\end{array}$ & [40] \\
\hline 14 & Solar/Wind & $\begin{array}{l}\text { Wind Turbine; CPVT; TES; } \\
\text { FC; EL; MSF; VCR; PRO }\end{array}$ & $\begin{array}{c}\text { Electricity; } \\
\text { Freshwater; Cooling; } \\
\text { Hydrogen }\end{array}$ & Energy/ Exergy & 73.3 & 30.6 & - & [41] \\
\hline 15 & Solar & ESC; MD & Freshwater & Economic & - & - & $\mathrm{PP}=4$ years & {$[42]$} \\
\hline \multicolumn{9}{|c|}{$\begin{array}{l}\text { Abbreviations: Reverse Osmosis: RO; Proton Exchange Membrane Fuel Cell: PEMFC; Absorption Refrigeration: ASR; Ammonia Fuel Cell: AFC; Organi } \\
\text { Rankin Cycle: ORC; Single Stage Evaporator: SSE; Photovoltaic: PV; Levelized Cost of Electricity: LCOE; Levelized Cost of water: LCOW; Paraboli } \\
\text { Through Collector: PTC; Trigeneration-based Gain-Output-Ratio: TGOR; Flash-Binary Geothermal Power Plant: FGPP; Humidification } \\
\text { Dehumidification unit: HDH; Kalina Cycle: KC; SUCP: Sum Unit Cost of Product; Domestic Hot Water: DHW; PCM: Phase Change Material; Stean } \\
\text { Cycle: SC; Solar Dish: SD; PP: Payback Period; CPVT: Concentrated Photovoltaics/Thermal; TES: Thermal Energy Storage; Electrolyzer: EL; Fuel Cell } \\
\text { FC; Multistage Flash Distillation: MSF; Vapor Compression Refrigeration: VCR; Pressure Retarded Osmosis: PRO; Evacuated Solar Collector: ESC }\end{array}$} \\
\hline
\end{tabular}




\subsection{Novelty of the Research}

After careful investigation of the multi/co-generation systems and different products from them, it is clear that the proposed system configuration has not been investigated yet. In this proposed system, three main sub-systems are considered that are power and cooling production (Goswami cycle [43-46]), Reverse Osmosis (RO) with a recovery turbine, hydrogen and sodium hypochlorite $(\mathrm{NaClO})$ production) that are powered by the geothermal energy resource.

Moreover, the products of this system (electrical power, cooling, freshwater, hydrogen, and sodium hypochlorite $(\mathrm{NaClO}))$ are different from the other systems which have been investigated in the literature.

The benefits of the proposed desalination system are varied and the key products are potable water (as main needs for humanity), hydrogen (a key clean fuel for the transportation sector), electrical and cooling energy (as needs for residential, commercial, and industrial applications), and sodiumhypochlorite (a valuable co-product).

Complete analyses covering all aspects of the system including energy, exergy, economic, exergoenvironmental, and environmental have not been considered for any system in the literature.

For the environmental analysis, the relation between environmental detrimental effects and economics is established by considering the social cost of environmental pollution. It is assumed the same amount of electrical power produced by this system is generated by non-renewable power generation systems and the air pollution gases $\left(\mathrm{CO}_{2}, \mathrm{NO}_{\mathrm{x}}, \mathrm{SO}_{2}, \mathrm{CO}\right)$ produced by these assumed systems are calculated. In this regard, four scenarios are defined.

By considering the social cost of these harmful gases, the effects of environmentally harmful gases on economics are evaluated.

The innovations of this paper are as follows:

- Energy, exergy, economic, exergoenvironmmental, and environmental analyses of the multigeneration system to produce electrical, cooling, potable water, hydrogen, and $\mathrm{NaClO}$ simultaneously 
- Establish a relationship between environmental negative effects and economics by considering the social cost of environmental pollution.

\section{Mathematical Modeling}

\subsection{Process Description and Assumptions}

Figure 1 shows the schematic diagram of the proposed system. This system has three sub-systems consisting of cooling and power production system (Goswami cycle), reverse osmosis (RO) with a recovery turbine, and $\mathrm{H}_{2} / \mathrm{NaClO}$ production plant.

The advantage of the Goswami cycle compared to the Kalina cycle is the cooling output, however, with higher temperature source, the Kalina cycle has a better performance [43].

In the power and cooling production system (Goswami cycle), the working fluid is a binary mixture of water and ammonia. This working fluid flows through pump III and it is pressurized (points 1 \& 2). After exchanging the heat with the heated lean ammonia-water mixture in the Recovery Heat Exchanger (RHX), it is transferred to the boiler (points 2, 3, 9 \& 10). In the boiler, the mixture is heated and it is sent to the rectifier/separator (point 4). In the rectifier/separator, the working fluid is divided into rich and lean mixtures (points $5 \& 9$ ). The lean mixture is transferred to the RHX (points $9 \& 10$ ). After reducing the pressure in the throttling valve (point 11), it is transferred to the absorber.

The rich mixture is heated in the superheater and it is converted to the superheated steam (point 6). This superheated steam rotates the turbine and generator to produce electrical power. Then, the low-pressure rich mixture goes through the Refrigeration Heat Exchanger (RHE) to produce cooling (points $7 \& 8$ ). In the absorber, the lean and rich mixtures are mixed (points $8,11 \& 1$ ).

The energy needs of the boiler and superheater are met to be supplied by the geothermal working fluid. After extraction of the geothermal working fluid from the production well (point 12), it is pressurized in the pump I (point 13) and then flows through the superheater and boiler to warm up the ammonia-water mixture (points $14 \& 15$ ).

In the RO, the seawater goes through high-pressure pumps (points 16, 17, 18, $19 \& 20$ ), and then it is transferred to the membranes I \& II to separate the salt. The potable water (points $21,23 \&$ 25 ) is stored in the water storage tank (point 26). The high-pressure drain rotates the recovery 
turbine (points 22, $24 \& 27$ ) to produce the electrical power (point 28). The part of the low-pressure drain water (point 29) is transferred to the $\mathrm{NaClO}$ plant to produce hydrogen and sodium hypochlorite $(\mathrm{NaClO})$ (points $30 \& 31)$.

In this system, the electrical power is produced in the turbine (Goswami cycle) and the recovery turbine. The part of this produced electricity is consumed internally by the pumps I to IV and $\mathrm{NaClO}$ plant. The remaining part can be used by consumers. The system Grassman diagram is shown in Figure 2. 


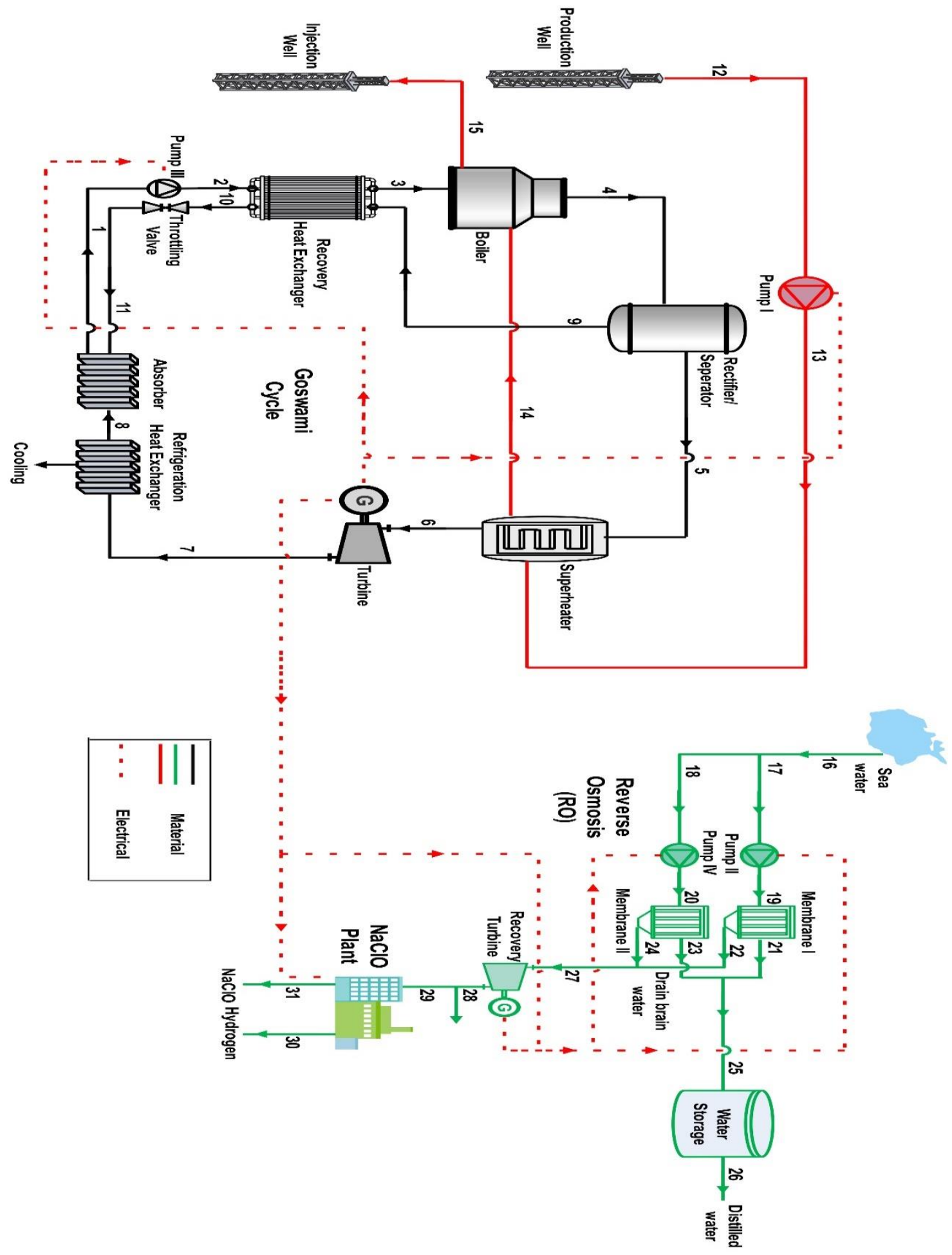

Figure 1. Proposed system schematic diagram 


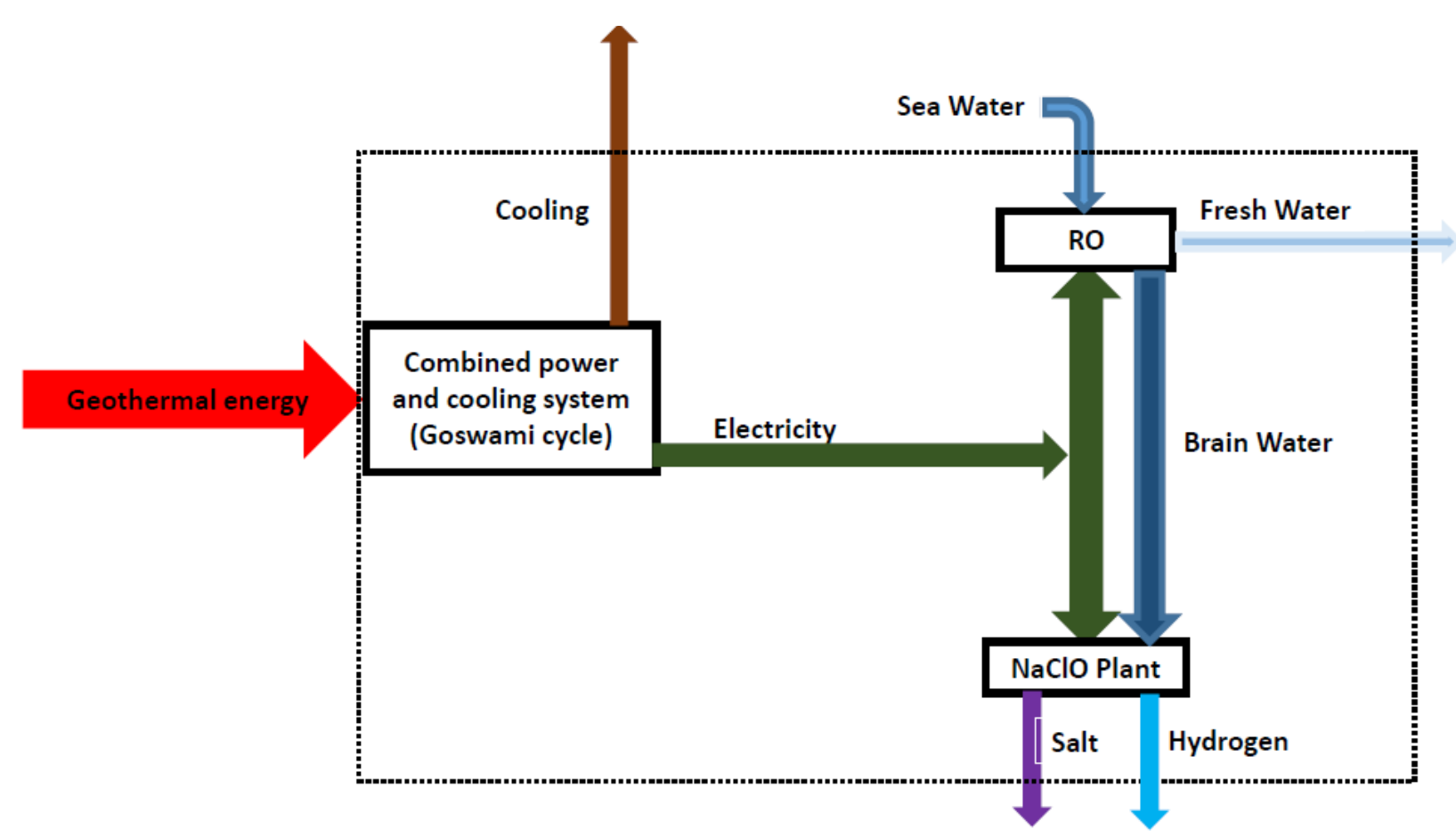

Figure 2. Grassman diagram of the system

The following assumptions are considered [23, 43, 47-54]:

1- Steady-state operation.

2- The pump and turbine polytrophic efficiencies are equal to $85 \%$, respectively.

3- The heat exchanger effectiveness factor is $85 \%$.

4- The geothermal working fluid pressure, temperature, and mass flow rate are equal to 2 bar, $120^{\circ} \mathrm{C}$, and $15 \mathrm{~kg} / \mathrm{s}$, respectively. The location of geothermal wells is in the Bandar Abbas city located in the southern of Iran. The type of geothermal resource is hydrothermal.

5- The dead state pressure and temperature are $15^{\circ} \mathrm{C}$ and $1 \mathrm{bar}$, respectively.

6- The potential and kinetic energy are neglected.

7- The pressure loss is neglected.

8- The process in the throttling valve is adiabatic.

9- The recovery ratio in the $\mathrm{RO}$ system is 0.3 .

10- Heat exchangers are shell and tube type.

11- In the environmental analysis, air pollution is considered as environmental pollutions.

12- The polarization effects are ignored in this study. 


\subsection{Mass, Concentration, and Energy Balance}

Generally, the mass and energy conservation equations are written as follows [55]:

$$
\begin{aligned}
& \sum_{\text {in }} \dot{m}=\sum_{\text {out }} \dot{m} \\
& \dot{Q}-\dot{W}=\sum_{P} \dot{m}\left(h_{f}+\left(h-h_{0}\right)\right)-\sum_{R} \dot{m}\left(h_{f}+\left(h-h_{0}\right)\right)
\end{aligned}
$$

In which $\dot{\mathrm{W}}$ and $\dot{\mathrm{Q}}$ are the work and heat transfer rate, $\mathrm{h}$ and $\dot{\mathrm{m}}$ are enthalpy and mass flow rate, respectively. Subscripts $\mathrm{P}, \mathrm{R}, \mathrm{f}$, and 0 mean product, reactant, formation, and dead state, respectively.

The mass, concentration, and energy balance equations for the combined power and cooling system (Goswami cycle) and geothermal loop are shown in Table 3 [56-58].

\begin{tabular}{|c|c|c|c|c|}
\hline No. & Components & Mass balance & Energy equation & $X$ \\
\hline \multicolumn{5}{|c|}{ Combined power and cooling system (Goswami cycle) } \\
\hline 1 & Pump III (P) & $\dot{m}_{1}=\dot{m}_{2}$ & $\dot{w}_{p I I I}=\dot{m}_{1}\left(h_{2}-h_{1}\right)$ & $X_{1}=X_{2}$ \\
\hline 2 & Throttling value & $\dot{m}_{10}=\dot{m}_{11}$ & $h_{10}=h_{11}$ & $X_{10}=X_{11}$ \\
\hline 3 & $\begin{array}{l}\text { Recovery heat } \\
\text { exchanger }\end{array}$ & $\begin{array}{l}\dot{m}_{3}=\dot{m}_{2} \\
\dot{m}_{10}=\dot{m}_{9}\end{array}$ & $\begin{array}{r}\dot{m}_{20}\left(h_{9}-h_{10}\right) \eta_{R H X} \\
=\dot{m}_{2}\left(h_{3}-h_{2}\right)\end{array}$ & $\begin{array}{l}X_{3}=X_{2} \\
X_{10}=X_{9}\end{array}$ \\
\hline 4 & Boiler & $\begin{array}{l}\dot{m}_{3}=\dot{m}_{4} \\
\dot{m}_{14}=\dot{m}_{15}\end{array}$ & $\begin{aligned} \dot{m}_{14}\left(h_{14}-h_{15}\right) \eta_{\text {Boiler }} & \\
& =\dot{m}_{3}\left(h_{4}-h_{3}\right)\end{aligned}$ & $X_{3}=X_{4}$ \\
\hline 5 & $\begin{array}{l}\text { Rectifier/ separator } \\
\text { (RS) }\end{array}$ & $\dot{m}_{4}=\dot{m}_{5}+\dot{m}_{9}$ & $\dot{m}_{4} h_{4}=\dot{m}_{5} h_{5}+\dot{m}_{9} h_{9}$ & $\dot{m}_{4} X_{4}=\dot{m}_{9} X_{9}+\dot{m}_{5} X_{5}$ \\
\hline 6 & Superheater (SH) & $\begin{array}{l}\dot{m}_{5}=\dot{m}_{6} \\
\dot{m}_{13}=\dot{m}_{14}\end{array}$ & $\dot{m}_{13}\left(h_{13}-h_{14}\right) \eta_{S H}=\dot{m}_{5}\left(h_{6}-h_{5}\right)$ & $X_{5}=X_{6}$ \\
\hline 7 & Turbine $(\mathrm{T})$ & $\dot{m}_{6}=\dot{m}_{7}$ & $\dot{w}_{T}=\dot{m}_{6}\left(h_{6}-h_{7}\right)$ & $X_{6}=X_{7}$ \\
\hline 8 & $\begin{array}{l}\text { Refrigeration heat } \\
\text { exchanger (RHE) }\end{array}$ & $\dot{m}_{7}=\dot{m}_{8}$ & $\dot{Q}_{R H E}=\dot{m}_{7}\left(h_{7}-h_{8}\right)$ & $X_{7}=X_{8}$ \\
\hline 9 & Absorber (Abs) & $\dot{m}_{8}+\dot{m}_{11}=\dot{m}_{1}$ & $\dot{Q}_{A b s}=\dot{m}_{8} h_{8}+\dot{m}_{11} h_{11}-\dot{m}_{1} h_{1}$ & $\dot{m}_{8} X_{8}+\dot{m}_{11} X_{11}=\dot{m}_{1} X_{1}$ \\
\hline \multicolumn{5}{|c|}{ Geothermal loop } \\
\hline 10 & Pump I (P) & $\dot{m}_{12}=\dot{m}_{13}$ & $\dot{w}_{p I}=\dot{m}_{12}\left(h_{12}-h_{13}\right)$ & - \\
\hline
\end{tabular}

Table 3. Mass, concentration, and energy balance equations for the Goswami cycle

In Table $3, \dot{m}, h, X$, and $\eta$ mean mass flow rate, enthalpy, ammonia mass ratio, and polythrophic efficiency for rotary equipment (pump and turbine), as well as, effectiveness factor for boiler, superheater, and heat exchangers. 
In RO sub-system, the mass and concentration balance equations are as follows $[49,59,60]$ :

$$
\begin{aligned}
& \dot{m}_{S W}=\dot{m}_{B W}+\dot{m}_{P W} \\
& \dot{m}_{S W} x_{S W}=\dot{m}_{P W} x_{P W}+\dot{m}_{B W} x_{B W}
\end{aligned}
$$

where $x$ is the salt concentration. Subscripts $S W, P W$, and $B W$ denote seawater, potable water, and brain water, respectively.

The relation between sea and portable water is as follows [49, 59]:

$$
\dot{m}_{P W}=R R \dot{m}_{S W}
$$

where RR is the recovery ratio.

Osmosis pressure for the three main streams are calculated by [49, 59]:

$$
\begin{aligned}
& \pi_{S W}=R T \times x_{S W} \\
& \pi_{P W}=R T \times x_{P W} \\
& \pi_{B W}=R T \times x_{B W}
\end{aligned}
$$

$\mathrm{R}$ is the universal gas constant.

The net pressure in the membrane is calculated by [49, 59]:

$$
\Delta \pi=\left(\frac{\pi_{S W}+\pi_{B W}}{2}\right)-\pi_{P W}
$$

The water permeability coefficient is calculated by $[49,59]$ :

$$
K_{W}=\frac{6.84 \times 10^{-8}\left(18.68-0.177 x_{B W}\right)}{T_{S W}}
$$

The net pressure of the RO pump is calculated by $[49,59]$ : 


$$
\Delta P=\frac{\dot{m}_{P W}}{K_{W} A_{m}}+\Delta \pi
$$

$A_{m}$ is the membrane area.

The power needs of the RO pump is calculated as $[49,59]$ :

$$
\dot{W}_{P, R O}=\frac{\Delta P \dot{m}_{S W}}{\rho_{S W} \eta_{P, R O}}
$$

where $\rho$ is the density.

The mass, concentration, and energy balance equations for the RO sub-system are presented in Table 4.

Table 4. Mass, concentration, and energy balance equations for the RO sub-system

\begin{tabular}{|l|l|c|c|c|}
\hline No. & Components & Mass balance & Energy equation & x \\
\hline 1 & Pump II & $\dot{m}_{17}=\dot{m}_{19}$ & $\dot{W}_{P I I}=\dot{m}_{17}\left(h_{19}-h_{17}\right)$ & $x_{17}=x_{19}$ \\
\hline 2 & Pump IV & $\dot{m}_{18}=\dot{m}_{20}$ & $\dot{W}_{P I V}=\dot{m}_{18}\left(h_{20}-h_{18}\right)$ & $x_{18}=x_{20}$ \\
\hline 3 & Membrane I & $\dot{m}_{19}=\dot{m}_{21}+\dot{m}_{22}$ & $\dot{m}_{19} h_{19}=\dot{m}_{21} h_{21}+\dot{m}_{22} h_{22}$ & $\dot{m}_{19} x_{19}=\dot{m}_{21} x_{21}+\dot{m}_{22} x_{22}$ \\
\hline 4 & Membrane II & $\dot{m}_{20}=\dot{m}_{23}+\dot{m}_{24}$ & $\dot{m}_{20} h_{20}=\dot{m}_{23} h_{23}+\dot{m}_{24} h_{24}$ & $\dot{m}_{20} x_{20}=\dot{m}_{23} x_{23}+\dot{m}_{24} x_{24}$ \\
\hline 5 & Recovery turbine & $\dot{m}_{27}=\dot{m}_{28}$ & $\dot{W}_{\text {Recovery turbine }=} \dot{m}_{27}\left(h_{27}-h_{28}\right)$ & $x_{27}=x_{28}$ \\
\hline
\end{tabular}

In which $\mathrm{x}$ means the concentration of salt.

In the $\mathrm{NaClO}$ plant, the following reaction happens:

$$
\mathrm{NaCl}+\mathrm{H}_{2} \mathrm{O} \rightarrow \mathrm{NaClO}+\mathrm{H}_{2}
$$

For the $\mathrm{NaClO}$ plant, the following relations between temperature and concentration ratio are considered [49, 59]: 


$$
\begin{aligned}
& T_{\text {NaClo }}=T_{B W}+14 \\
& x_{\text {NaClO }}=\frac{1}{6} x_{B W}
\end{aligned}
$$

The power need of the $\mathrm{NaClO}$ plant is calculated by $[49,59]$ :

$$
\dot{W}_{\text {NaClO }}=\frac{10^{-5}\left(5.9 \times 3600 \times \dot{\mathrm{m}}_{\text {NaClO }} \times x_{N a C l O}\right)}{1.05}
$$

Table 5 shows the mass, concentration, and energy balance equations for the $\mathrm{NaClO}$ plant.

Table 5. Mass, concentration, and energy balance equations for the $\mathrm{NaClO}$ plant.

\begin{tabular}{|l|c|}
\hline Mass balance & $\dot{m}_{29}=\dot{m}_{30}+\dot{m}_{31}$ \\
\hline Concentration balance & $\dot{m}_{29} x_{29}=\dot{m}_{30} x_{30}+\dot{m}_{31} x_{31}$ \\
\hline Energy balance & $\dot{m}_{29} h_{29}+\dot{W}_{N a C l O}=\dot{m}_{31} h_{31}+\dot{m}_{30} h_{30}$ \\
\hline
\end{tabular}

The electrical power production equations for the Goswami, Goswami/RO, and system plants are shown below:

$$
\begin{aligned}
& \dot{W}_{\text {net,Goswami }}=\dot{W}_{T}-\dot{W}_{P, I}-\dot{W}_{P, I I I} \\
& \dot{W}_{\text {net,Goswami } / R O}=\dot{W}_{T}+\dot{W}_{\text {recovery turbine }}-\sum_{i=1}^{4} \dot{W}_{P, i} \\
& \dot{W}_{\text {net,sys }}=\dot{W}_{T}+\dot{W}_{\text {recovery turbine }}-\sum_{i=1}^{4} \dot{W}_{P, i}-\dot{W}_{N a C l o}
\end{aligned}
$$

The energy efficiency equations for the Goswami, Goswami/RO, and system plants are defined as:

$$
\begin{aligned}
& \eta_{\text {en,Gowsami }}=\frac{\dot{W}_{\text {net,Goswami }}}{\dot{m}_{12}\left(h_{12}-h_{15}\right)} \\
& \eta_{\text {en,Gowsami/Ro }}=\frac{\dot{W}_{\text {net }, \text { Goswami/RO }+\dot{m}_{25} h_{25}}}{\dot{m}_{12}\left(h_{12}-h_{15}\right)}
\end{aligned}
$$




$$
\eta_{\text {en }, \text { system }}=\frac{\dot{m}_{31} h_{31}+\dot{m}_{30} h_{30}+\dot{m}_{25} h_{25}+\dot{W}_{\text {net }, \text { Goswami } / R O / N a C l O}}{\dot{m}_{12}\left(h_{12}-h_{15}\right)}
$$

\subsection{Exergy Analysis}

Exergy analysis is carried out by including four parts which are physical, chemical, kinetic, and potential. Specific exergy equation is written below [61, 62]:

$$
e=\sum x_{i} e x_{c h i}+\frac{V^{2}}{2}+g z+\left(h-h_{0}\right)-T_{0}\left(s-s_{0}\right)+T_{0} \sum x_{i} R_{i} \ln y_{i}
$$

$\mathrm{e}$ and $\mathrm{x}$ are specific exergies and mass fraction. $\mathrm{V}, \mathrm{g}$, and $\mathrm{z}$ are defined as velocity, gravitational acceleration, and height. h, T, s, y are specific enthalpy, entropy, temperature, and mole fraction. Abbreviations ch, i, and 0 are defined as chemical, species, and dead state condition.

Tables 6, 7, and 8 show the exergy destruction rate and exergy efficiency for each component of the combined power and cooling system and geothermal loop (Goswami cycle), $\mathrm{RO}$, and $\mathrm{NaClO}$ plant, respectively.

Table 6. Exergy efficiency and exergy destruction rate for each component of the combined

\begin{tabular}{|c|c|c|c|}
\hline No. & Components & Exergy efficiency & Exergy destruction rate $(\mathrm{kW})$ \\
\hline \multicolumn{4}{|c|}{ Combined power and cooling system (Goswami cycle) } \\
\hline 1 & Pump III (P) & $\frac{\dot{W}_{P I I I}}{\dot{m}_{1}\left(e_{2}-e_{1}\right)}$ & $\dot{m}_{1} e_{1}-\dot{m}_{2} e_{2}+\dot{W}_{P I I I}$ \\
\hline 2 & Throttling value & $\frac{\dot{m}_{11} e_{11}}{\dot{m}_{10} e_{10}}$ & $\dot{m}_{11} e_{11}-\dot{m}_{10} e_{10}$ \\
\hline 3 & $\begin{array}{l}\text { Recovery heat } \\
\text { exchanger }\end{array}$ & $\frac{\dot{m}_{2}\left(e_{3}-e_{2}\right)}{\dot{m}_{20}\left(e_{9}-e_{10}\right)}$ & $\dot{m}_{2} e_{2}+\dot{m}_{9} e_{9}-\dot{m}_{3} e_{3}-\dot{m}_{10} e_{10}$ \\
\hline 4 & Boiler & $\frac{\dot{m}_{3}\left(e_{4}-e_{3}\right)}{\dot{m}_{11}\left(e_{14}-e_{15}\right)}$ & $\begin{aligned} \dot{m}_{3} e_{3}+\dot{m}_{14} e_{14}- & \dot{m}_{15} e_{15} \\
& -\dot{m}_{4} e_{4}\end{aligned}$ \\
\hline 5 & $\begin{array}{l}\text { Rectifier/ separator } \\
\text { (RS) }\end{array}$ & $\frac{\dot{m}_{5} e_{5}+\dot{m}_{9} e_{9}}{\dot{m}_{4} e_{4}}$ & $\dot{m}_{4} e_{4}-\dot{m}_{5} e_{5}-\dot{m}_{9} e_{9}$ \\
\hline 6 & Superheater $(\mathrm{SH})$ & $\frac{\dot{m}_{5}\left(e_{6}-e_{5}\right)}{\dot{m}_{6}\left(e_{13}-e_{14}\right)}$ & $\begin{aligned} \dot{m}_{13} e_{13}+\dot{m}_{5} e_{5}- & \dot{m}_{6} e_{6} \\
& -\dot{m}_{14} e_{14}\end{aligned}$ \\
\hline 7 & Turbine $(\mathrm{T})$ & $\dot{m}_{6}\left(e_{6}-e_{7}\right)-\dot{W}_{T}$ & $\frac{\dot{W}_{T}}{\dot{m}_{6}\left(e_{6}-e_{7}\right)}$ \\
\hline 8 & $\begin{array}{l}\text { Refrigeration heat } \\
\text { exchanger (RHE) }\end{array}$ & $\dot{m}_{7}\left(e_{7}-e_{8}\right)-\dot{Q}_{R H E}\left(1-\frac{T_{8}}{T_{0}}\right)$ & $\frac{\dot{Q}_{R H E}\left(1-\frac{T_{8}}{T_{0}}\right)}{\dot{m}_{7}\left(e_{7}-e_{8}\right)}$ \\
\hline
\end{tabular}
power and cooling system and geothermal loop (Goswami cycle) 


\begin{tabular}{|c|l|c|c|}
\hline 9 & Absorber (Abs) & $\dot{m}_{8} e_{8}+\dot{m}_{11} e_{11}-\dot{m}_{1} e_{1}-\dot{Q}_{a b s}$ & $\frac{\dot{\boldsymbol{m}}_{\mathbf{1}} \boldsymbol{e}_{\mathbf{1}}}{\dot{\boldsymbol{m}}_{\mathbf{8}} \boldsymbol{e}_{\mathbf{8}}+\dot{\boldsymbol{m}}_{\mathbf{1 1}} \boldsymbol{e}_{\mathbf{1 1}}-\dot{\boldsymbol{Q}}_{\boldsymbol{a b s}}}$ \\
\hline \multicolumn{3}{|c|}{ Geothermal loop } \\
\hline 10 & Pump I (P) & $\frac{\dot{W}_{P I}}{\dot{m}_{1}\left(e_{13}-e_{12}\right)}$ & $\dot{\boldsymbol{m}}_{\mathbf{1 2}} \boldsymbol{e}_{\mathbf{1 2}}-\dot{\boldsymbol{m}}_{\mathbf{1 3}} \boldsymbol{e}_{\mathbf{1 3}}+\dot{W}_{\boldsymbol{P I I I}}$ \\
\hline
\end{tabular}

Table 7. Exergy destruction rate and exergy efficiency for each component of the RO system

\begin{tabular}{|l|l|c|c|}
\hline No. & Components & Exergy efficiency & Exergy destruction rate (kW) \\
\hline 1 & Pump II & $\frac{\dot{W}_{P I I}}{\dot{m}_{17}\left(e_{19}-e_{17}\right)}$ & $\dot{m}_{17}\left(e_{17}-e_{19}\right)+\dot{W}_{P I I}$ \\
\hline 2 & Pump IV & $\frac{\dot{W}_{P I V}}{\dot{m}_{18}\left(e_{20}-e_{18}\right)}$ & $\dot{m}_{18}\left(e_{18}-e_{20}\right)+\dot{W}_{P I V}$ \\
\hline 3 & Membrane I & $\frac{\dot{m}_{21} e_{21}}{\dot{m}_{19} e_{19}}$ & $\dot{m}_{19} e_{19}-\dot{m}_{21} e_{21}-\dot{m}_{22} e_{22}$ \\
\hline 4 & Membrane II & $\frac{\dot{m}_{23} e_{23}}{\dot{m}_{20} e_{20}}$ & $\dot{m}_{20} e_{20}-\dot{m}_{23} e_{23}-\dot{m}_{24} e_{24}$ \\
\hline 5 & Recovery turbine & $\frac{\dot{W}_{\text {recovery turbine }}}{\dot{m}_{17}\left(e_{27}-e_{28}\right)}$ & $\dot{m}_{27} e_{27}-\dot{m}_{28} e_{28}-\dot{W}_{\text {recovery turbine }}$ \\
\hline
\end{tabular}

Table 8. Exergy efficiency and exergy destruction rate for each component of the $\mathrm{NaClO}$ plant

\begin{tabular}{|l|c|}
\hline Exergy efficiency & $\frac{\dot{m}_{31} e_{31}}{\dot{W}_{N a C l O}}$ \\
\hline Exergy destruction rate & $\dot{m}_{29} e_{29}+\dot{W}_{N a C l O}-\dot{m}_{30} e_{30}-\dot{m}_{31} e_{31}$ \\
\hline
\end{tabular}

The exergy efficiency equations for the Goswami, Goswami/RO, and system are presented below:

$$
\begin{aligned}
& \eta_{\text {ex,Gowsami }}=\frac{\dot{W}_{\text {net }, \text { Goswami }}}{\dot{m}_{12}\left(e_{12}-e_{15}\right)} \\
& \eta_{\text {ex,Gowsami } / R O}=\frac{\dot{W}_{\text {net }, \text { Goswami } / R O+\dot{m}_{25} e_{25}}}{\dot{m}_{12}\left(e_{12}-e_{15}\right)} \\
& \eta_{\text {ex,sys }}=\frac{\dot{W}_{\text {net }, \text { sys }}+\dot{m}_{31} e_{31}+\dot{m}_{30} e_{30}+\dot{m}_{25} e_{25}}{\dot{m}_{12}\left(e_{12}-e_{15}\right)}
\end{aligned}
$$

\subsection{Economic Evaluation}

The cogeneration annual income $\mathrm{CF}$ is calculated as follows [63, 64]: 


$$
C F=Y_{\text {power }} k_{\text {power }}+Y_{\text {cooling }} k_{\text {cooling }}+Y_{P W} k_{P W}+Y_{\text {NaCl }} k_{\mathrm{NaCl}}+Y_{H 2} k_{H 2}
$$

where $\mathrm{k}$ and $\mathrm{Y}$ are products specific cost and annual capacity of system productions. The production costs are shown in Table 9.

Table 9. Specific cost of fuel and products

\begin{tabular}{|c|c|c|c|}
\hline Specific cost of products & Unit & Value & Ref. \\
\hline $\mathbf{k}_{\text {power }}$ & $\mathrm{US} \$ / \mathrm{kWh}$ & 0.22 & [65] \\
\hline kPW & $\mathrm{US} \$ / \mathrm{kg}$ & 0.0004 & [66] \\
\hline $\mathbf{k}_{\text {cooling }}$ & US $\$ / \mathrm{kWh}$ & 0.07 & [67] \\
\hline $\mathbf{k N a C l}_{\mathrm{Na}}$ & $\mathrm{US} \$ / \mathrm{kg}$ & 10.5 & [68] \\
\hline $\mathrm{k}_{\mathrm{H} 2}$ & US\$ $/ \mathrm{kg}$ & 13.99 & [69] \\
\hline
\end{tabular}

The system investment cost equation is given below $[63,64]$ :

$$
C_{0}=K_{\text {Goswami }}+K_{\text {Geothermal loop }}+K_{R O}+K_{\text {NaClo }}
$$

$\mathrm{K}$ is the investment and installation cost of each subsystem shown in Table 10. For the operation and maintenance cost, $3 \%$ of the initial cost is considered [63, 64].

Table 10. $\mathrm{K}$ values for different components

\begin{tabular}{|c|c|c|c|}
\hline No. & Components & Cost function & Ref \\
\hline \multicolumn{4}{|c|}{ Combined power and cooling system (Goswami cycle) } \\
\hline 1 & Pump & $1120 \dot{W}^{0.8}$ & {$[70-73]$} \\
\hline
\end{tabular}




\begin{tabular}{|c|c|c|c|}
\hline 2 & Throttling value & Neglected & {$[50,74]$} \\
\hline 3 & Heat exchanger & $588 A^{0.8}$ & [70-72] \\
\hline 4 & Boiler & $588 A^{0.8}$ & {$[70-72]$} \\
\hline 5 & Superheater (SH) & $588 A^{0.8}$ & {$[70-72]$} \\
\hline 6 & Turbine & $4405 \dot{W}^{0.7}$ & [70-73] \\
\hline 7 & Rectifier/Separator & $\left.\begin{array}{l}\frac{576.1}{397} 10^{\left(3.4974+0.4485 \log \left(V_{\text {sep }}\right)+0.1074\left(\log \left(V_{\text {sep }}\right)\right)^{2}\right)}(2.25 \\
+1.82 \text { maximum }\left\{\frac{\left(P_{\text {sep }}+1\right) D_{\text {sep }}}{2\left[850-0.6\left(P_{\text {sep }}+1\right)\right]}+0.00315\right. \\
0.0063\end{array}\right\}$ & {$[75]$} \\
\hline 8 & Absorber (Abs) & $0.322\left(30000+0.75 A^{0.8}\right)$ & [66] \\
\hline \multicolumn{4}{|c|}{ Geothermal loop } \\
\hline 9 & Pump & $3540 \dot{W}^{0.71}$ & {$[76,77]$} \\
\hline 10 & Drilling well & $16.5 z^{1.607}$ & [78] \\
\hline \multicolumn{4}{|c|}{$\mathbf{R O}$} \\
\hline 11 & Pump & $996(86400 \dot{Q})^{0.8}$ & [79] \\
\hline 12 & Membrane & 50 & [67] \\
\hline 13 & Tank & $1.14\left(158,62 V_{\text {Tank }}+18321\right.$ & {$[80]$} \\
\hline 14 & Recovery turbine & $52\left(86400 \dot{Q} \Delta P^{0.8}\right)$ & {$[79]$} \\
\hline \multicolumn{4}{|c|}{ NaClO Plant } \\
\hline 15 & $\begin{array}{l}\text { NaClO Plant } \\
\text { (Model HD:6000) }\end{array}$ & 45000 & {$[81]$} \\
\hline
\end{tabular}

In Table 10, z, D, and V mean depth of geothermal well, diameter, and volume, respectively. Subscript sep denotes separator.

For estimating the surface area of the heat exchanger, the logarithmic method is applied. In this regard, the following equation is considered [82]:

$\dot{Q}=U A F_{t} \Delta T_{I n}$

where $\dot{Q}, U, A, F_{t}$, and $\Delta T_{I n}$ are the heat transfer rate, overall heat transfer coefficient, surface area, correction factor, and logarithmic mean temperature difference. The overall heat transfer coefficient for various components is shown in Table 10 [50]. The method for estimating the volume of the separator is explained in Ref. [83]. 
Table 11. U values for various components

\begin{tabular}{|c|c|c|}
\hline No. & Components & $\boldsymbol{U}\left(\boldsymbol{W} / \boldsymbol{m}^{2} \boldsymbol{K}\right)$ \\
\hline 1 & Separator & 300 \\
\hline 2 & Boiler & 500 \\
\hline 3 & Heat exchanger & 700 \\
\hline 4 & Absorber & 800 \\
\hline
\end{tabular}

Since the cost function is based on various years, the effect of inflation can be represented by the following equation [84]:

$$
C_{n}=C_{0}(1+i)^{n}
$$

where $\mathrm{n}$ is the number of years, and $\mathrm{i}$ is the inflation rate which is equal to $3.11 \%$ [85].

The simple payback period (SPP) index is calculated by [63, 64]:

$$
S P P=\frac{C_{n}}{C F}
$$

The payback period (PP) index can be expressed as $[63,64]$ :

$$
P P=\frac{\ln \left(\frac{C_{F}}{C F-r \cdot C_{n}}\right)}{\ln (1+r)}
$$

where $\mathrm{r}$ represents the discount factor $(3 \%)$.

The Net Present Value (NPV) is obtained as [63, 64]:

$$
N P V=C F \frac{(1+r)^{N}-1}{r(1+r)^{N}}-C_{n}
$$

$\mathrm{N}$ is the project lifetime that is considered 25 years.

The Internal Rate of Return (IRR) is given by [63, 64, 86]:

$$
I R R=\frac{C F}{C_{n}}\left[1-\frac{1}{(1+I R R)^{N}}\right]
$$




\subsection{Exergoenvironmental Analysis}

To investigate the system from the combination of exergy and environmental perspective, exergoenvironmental analysis is considered. The exergoenvironment factor which is affected by the exergy destruction rate is shown below [87-89]:

$$
f_{e i}=\frac{\dot{\mathrm{E}}_{D}}{\sum \dot{\mathrm{E}}_{i n}}
$$

In equation (35), subscripts $D$ and in are destruction and input. The environmental damage effectiveness factor can be calculated as [87-89]:

$$
\Theta_{e i}=f_{e i} \cdot C_{e i}
$$

$C_{e i}$ is the exergoenvironmental impact coefficient which is calculated by [87-89]:

$$
C_{e i}=\frac{1}{\eta_{e x}}
$$

In equation (37), $\eta_{e x}$ is the system exergy efficiency. The exergoenvironmental impact is expressed as [87-89]:

$$
\Theta_{e i i}=\frac{1}{\Theta_{e i}}
$$

The exergy stability factor is given by [87-89]:

$$
f_{e s}=\frac{\dot{\mathrm{E}}_{D}}{\dot{\mathrm{E}}_{\text {out }}+\dot{\mathrm{E}}_{D}+1}
$$

\subsection{Environmental Analysis}

To establish the relation between environmental air pollution and economics, the social cost of air pollution is considered. The social cost of air pollution is the cost associated with the harmful 
effects of air pollution on society. These effects are including diseases, deaths, etc. This cost can vary from one region to another. Also, the standard of living affects this cost. Further explanations are provided in ref. [90, 91].

The air pollution factors are not limited to these categories. Other sources of pollution such as water, soil, and noise... are existing that are ignored in this work because no data is existing in the literature, and the effects of these pollutions are much lower than air pollution.

In addition, during the components system production, various kinds of environmental pollution are produced that are out of the scope of this work. The environmental pollution produced during the operation time is related to life cycle analysis (LCA) and it can be investigated in future research $[90,91]$.

In order to establish a relationship between the environmental pollution and economics direct/indirect effect, four scenarios are considered. In all scenarios, it is assumed that the same amount of electrical power produced by the proposed system in this work, is produced by nonrenewable energy resource power production systems. These scenarios are as follows:

Scenario I: Natural gas-fueled gas turbine power plant

Scenario II: Gas oil-fueled gas turbine power plant

Scenario III: Coal-fired steam power plant

Scenario IV: Natural gas-fueled gas turbine with heat recovery boiler and steam turbine

The social cost of air pollution for carbon dioxide $\left(\mathrm{CO}_{2}\right)$, nitrogen oxide (NOx), and sulfur dioxide $\left(\mathrm{SO}_{2}\right)$ are presented in Table $12[90,91]$. The four scenarios with air pollution generation are shown in Table 13 [92]. 
Table 12. Social cost of air pollution for $\mathrm{CO}_{2}, \mathrm{NOx}$, and $\mathrm{SO}_{2}$

\begin{tabular}{|c|c|c|}
\hline Pollution & Unit & Values \\
\hline $\mathrm{CO}_{2}$ & \multirow{3}{*}{ US $\$ / \mathrm{kg}$} & 0.042 \\
\cline { 1 - 1 } $\mathrm{NO}_{\mathrm{x}}$ & & 7.3 \\
\cline { 1 - 1 } $\mathrm{SO}_{2}$ & & 7.4 \\
\hline
\end{tabular}

Table 13. Four scenarios and air pollution generation [92]

\begin{tabular}{|c|c|c|c|c|c|}
\hline Scenario & Power plant types & Fuel & $\begin{array}{c}\mathbf{C O}_{2} \\
(\mathbf{g} / \mathbf{k W h})\end{array}$ & $\begin{array}{c}\mathbf{N O} \\
(\mathbf{g} / \mathbf{k W h})\end{array}$ & $\begin{array}{c}\mathbf{S O}_{2} \\
(\mathbf{g} / \mathbf{k W h})\end{array}$ \\
\hline 1 & Gas turbine power plant & NG & 610 & 1.1 & - \\
\hline 2 & $\begin{array}{c}\text { Gas turbine power plant } \\
3\end{array}$ & $\begin{array}{c}\text { GO } \\
\text { plant }\end{array}$ & 800 & 1.6 & 1.4 \\
\hline 4 & $\begin{array}{c}\text { Gas turbine with heat } \\
\text { recovery boiler and } \\
\text { steam turbine }\end{array}$ & NG & 510 & 0.9 & - \\
\hline
\end{tabular}

In the proposed system of this study, since the system does not produce any air pollution during the operation time, it can be considered as a benefit of this system. So, cogeneration annual income (CF) can be considered by the following expression to show the effect of the social cost of air pollution:

$$
\begin{gathered}
C F=Y_{\text {power }} k_{\text {power }}+Y_{\text {cooling }} k_{\text {cooling }}+Y_{\mathrm{PW}} k_{\mathrm{PW}}+Y_{\mathrm{NaCl}} k_{\mathrm{NaCl}} \\
+Y_{\mathrm{H} 2} k_{\mathrm{H} 2}+Y_{\mathrm{CO} 2} k_{\mathrm{CO} 2}+Y_{\mathrm{SO} 2} k_{\mathrm{SO} 2}+Y_{\mathrm{NO} x} k_{\mathrm{NO}}
\end{gathered}
$$

where Y represents the annual air pollution generated by different scenarios depicted in Table 13, and $\mathrm{k}$ is the social cost of various air pollutions shown in Table 12. 


\section{Results and Discussion}

\subsection{Description of the Simulation Method}

After the mathematical modeling of the system, a computer program code was developed in engineering equation solver (EES) software. For the mixture of ammonia/water mixture properties calculation, the subroutine $\left(\mathrm{NH}_{3} \mathrm{H}_{2} \mathrm{O}\right)$ which is existing in the external library of the EES is used. Other working fluids' properties exist in EES software and they can be used easily by definition of thermodynamic function. The input information of the simulation program is depicted in Table 14.

Table 14. Input information of the simulation code

\begin{tabular}{|c|c|c|c|}
\hline Parameter & Unit & Value & Ref \\
\hline $\boldsymbol{X}_{\boldsymbol{I}}$ & - & 0.53 & {$[45]$} \\
\hline $\boldsymbol{X}_{\boldsymbol{4}}$ & - & 0.94 & {$[45]$} \\
\hline $\boldsymbol{X}_{5}$ & - & 0.99 & {$[45]$} \\
\hline$\dot{\boldsymbol{m}}_{\boldsymbol{I}}$ & $\mathrm{kg} / \mathrm{s}$ & 0.4 & - \\
\hline $\boldsymbol{T}_{\boldsymbol{I}}$ & $\mathrm{K}$ & 280 & {$[45]$} \\
\hline $\boldsymbol{T}_{5}$ & $\mathrm{~K}$ & 348 & {$[45]$} \\
\hline $\boldsymbol{T}_{7}$ & $\mathrm{~K}$ & 278 & {$[45]$} \\
\hline $\boldsymbol{P}_{\boldsymbol{I}}$ & $\mathrm{kPa}$ & 202.6 & {$[45]$} \\
\hline $\boldsymbol{P}_{2}$ & $\mathrm{kPa}$ & 3039 & {$[45]$} \\
\hline $\boldsymbol{x}_{16}$ & $\mathrm{mg} / \mathbf{l}$ & 40200 & {$[93]$} \\
\hline $\boldsymbol{x}_{27}$ & $\mathrm{mg} / \mathbf{l}$ & 150 & {$[93]$} \\
\hline $\boldsymbol{A}_{\boldsymbol{m}}$ & $\mathrm{m}{ }^{2}$ & 35.3 & {$[94]$} \\
\hline $\mathbf{R R}$ & - & 0.3 & {$[59]$} \\
\hline$\dot{\boldsymbol{m}}_{16}$ & $\mathrm{~kg} / \mathrm{s}$ & 2 & - \\
\hline
\end{tabular}

\subsection{Model Validation}

Since the whole plant has not been investigated yet, the validation of the whole plant by using experimental data is not feasible. Thus, each of the sub-systems has been validated individually. 
For validation of the combined power and cooling sub-systems (Goswami cycle), ref. [56] is considered. The input information of that reference is inserted into the computer simulation program. Table 15 shows the results of the comparison between the simulation model of this work with ref. [56].

Table 15. Results of the comparison between the simulation model with ref. [56]

\begin{tabular}{|c|c|c|c|c|c|}
\hline \multirow{2}{*}{ No. } & \multirow{2}{*}{$\mathbf{P}_{\mathbf{1}}(\mathbf{k P a})$} & \multirow{2}{*}{$\mathbf{P}_{\mathbf{2}}(\mathbf{k P a})$} & \multicolumn{3}{|c|}{$\eta_{\text {en }}$} \\
\cline { 4 - 6 } & & & Model & Ref[56] & Error(\%) \\
\hline 1 & 673.6 & 12124.8 & 3.54 & 3.5 & 1.2 \\
\hline 2 & 673.6 & 12798.4 & 2.98 & 2.8 & 4.2 \\
\hline 3 & 673.6 & 13472 & 2.36 & 2.2 & 2.5 \\
\hline
\end{tabular}

The comparison shows that the errors in the three situations are $1.2 \%, 4.2 \%$, and $2.5 \%$, respectively.

For validation of the RO system, the ref. [59] is considered. The data from the table of that reference is inserted into the computer code. Table 16 shows the comparison between the results of the RO system and ref. [59]. The minimum and maximum errors are $0.7 \%$ and $7 \%$, respectively. For validation of the $\mathrm{NaClO}$ plants, the ref. [81] is considered. The electrical power requirement of the $\mathrm{NaClO}$ plant is $4 \mathrm{~kW}$ while it is $3.78 \mathrm{~kW}$ in the computer code developed for this study. The error is around $5.5 \%$. The reason for this error is that the salt concentration in the feed mixture is unknown in ref. [81].

In conclusion, the developed computational code provides consistent results for each process subsystems, in agreement with the previously published data. 
Table 16. Comparison between the results of the RO system and ref. [59]

\begin{tabular}{|c|c|c|c|c|c|c|c|c|c|c|c|}
\hline \multicolumn{2}{|c|}{$\dot{\text { m}}_{\text {brain }}\left(\frac{\boldsymbol{k g}}{\boldsymbol{s}}\right)$} & \multicolumn{3}{c|}{$\dot{\mathrm{m}}_{P W}\left(\frac{k g}{s}\right)$} & \multicolumn{3}{c|}{$\dot{\mathrm{W}}_{\text {recovery turbine }}(\mathrm{kW})$} & \multicolumn{3}{c|}{$\dot{\mathrm{W}}_{P, \text { RO }}(k W)$} \\
\hline Model & Ref & Error(\%) & Model & Ref & Error(\%) & Model & Ref & Error(\%) & Model & Ref & Error(\%) \\
\hline 1.092 & 1.104 & 0.7 & 0.468 & 0.456 & 2.6 & 3.45 & 3.711 & 7 & 8.42 & 8.96 & 6 \\
\hline
\end{tabular}

\subsection{Energy and Exergy Analyses}

Table 17 shows the thermodynamic properties for each point of the system. Table 18 shows the annual system productions. By using this system, 1.075 GJ/year electrical energy, 1.04 GJ/year cooling energy, $18106.8 \mathrm{~m}^{3} /$ year potable water, 7.396 Ton/year hydrogen, and 3.838 Ton/year salt are produced annually. The cooling and electrical energy in the combined cooling and power system are close. The ratio of cooling to electrical energy is 0.97 (around unit).

Figure 3 shows the system power production in three configurations (Goswami, Goswami/RO, Goswami/RO/NaClO(global system)). It is clear that by adding the $\mathrm{RO}$ and $\mathrm{NaClO}$ plants to the system, power production declines to 36.78 and $37.09 \mathrm{~kW}$, respectively due to electrical power consumption of the $\mathrm{RO}$ and $\mathrm{NaClO}$ plants.

Figure 4 shows the energy and exergy efficiencies for three different configurations (Goswami, Goswami/RO, global system). It can be found that adding the RO system to the Goswami cycle increases the system energy efficiency from $10.2 \%$ to $12.4 \%$. From the energy point of view, although adding the RO system to the Goswami cycle reduces the electrical power production, the freshwater is also produced in the system $\left(\dot{m}_{25} h_{25}\right)$. The amount of this increase overcomes the reduction of the electrical power consumed in the RO system, since it adds the energy rate of the fresh water to the numerator of energy efficiency. From an exergy point of view, adding the RO system to the Goswami cycle is not beneficial, since it reduces the exergy efficiency from $25.6 \%$ to $20.2 \%$. It means that the electrical power exergy rate has a higher value than the freshwater 
exergy rate. The reason for this phenomenon is that the RO system operates near the dead state $\left(25^{\circ} \mathrm{C}, 101.3 \mathrm{kPa}\right)$. So, the value of $\left(\dot{\mathrm{m}}_{25} \mathrm{e}_{25}\right)$ in equation 25 is low. Adding the $\mathrm{NaClO}$ plant to the Goswami/RO reduces the energy and exergy efficiencies slightly from $12.4 \%$ and $20.2 \%$ to $12.25 \%$ and $19.6 \%$, respectively. In both energy and exergy analyses, the penalty of consumed electrical power by the $\mathrm{NaClO}$ plant is higher than the products amount of energy and exergy. However, the small amount of electrical power consumed in $\mathrm{NaClO}$ plant compensates with the recovery turbine.

Table 17. Thermodynamic properties for each point of the system

\begin{tabular}{|c|c|c|c|c|c|}
\hline No. & $\dot{\mathbf{m}} \mathbf{( k g / s )}$ & $\mathbf{T}(\mathbf{K})$ & $\mathbf{P}(\mathbf{k P a})$ & $\begin{array}{c}\mathbf{h} \\
\mathbf{( k J} / \mathbf{k g})\end{array}$ & $\mathbf{e}(\mathbf{k J} / \mathbf{k g})$ \\
\hline 1 & 0.4 & 280 & 202.6 & -208.9 & -20.8 \\
\hline 2 & 0.4 & 282 & 3039 & -197 & -17.62 \\
\hline 3 & 0.4 & 287.4 & 3039 & -172.5 & -17.9 \\
\hline 4 & 0.4 & 373 & 3039 & 1287 & 320.7 \\
\hline 5 & 0.3429 & 348 & 3039 & 1273 & 324.1 \\
\hline 6 & 0.3429 & 378 & 3039 & 1437 & 361.3 \\
\hline 7 & 0.3429 & 278 & 202.6 & 1268 & -1.841 \\
\hline 8 & 0.3429 & 303 & 202.6 & 1364 & -0.6563 \\
\hline 9 & 0.05714 & 348 & 3039 & 132 & 26.04 \\
\hline 10 & 0.05714 & 305 & 3039 & -69.66 & 2.402 \\
\hline 11 & 0.05714 & 305 & 202.6 & 532.1 & -8.933 \\
\hline 12 & 15 & 393.2 & 202.6 & 503.8 & 52.1 \\
\hline 13 & 15 & 393.2 & 263.4 & 498.6 & 52.16 \\
\hline 14 & 15 & 391.9 & 255.5 & 444.7 & 50.9 \\
\hline 15 & 15 & 379.2 & 247.8 & 59.45 & 38.68 \\
\hline 16 & 2 & 298.2 & 101.3 & 59.45 & 13.46 \\
\hline 17 & 1 & 298.2 & 101.3 & 59.45 & 13.46 \\
\hline 18 & 1 & 298.2 & 101.3 & 63.69 & 13.46 \\
\hline 19 & 1 & 298.2 & 4767 & 63.69 & 17.98 \\
\hline 20 & 1 & 298.2 & 4767 & 67.49 & 17.98 \\
\hline 21 & 0.3 & 298.2 & 4767 & 61.83 & 4.659 \\
\hline 22 & 0.7 & 298.2 & 4767 & 67.49 & 6.596 \\
\hline 23 & 0.3 & 298.2 & 4767 & 61.83 & 4.659 \\
\hline 24 & 0.7 & 298.2 & 4767 & 67.49 & 6.596 \\
\hline 25 & 0.6 & 298.2 & 4767 & 63.05 & 4.659 \\
\hline 26 & 0.6 & 298.2 & 101.3 & 61.83 & 0.000242 \\
\hline 27 & 1.4 & 298.2 & 4767 & 57.84 & 6.596 \\
\hline 28 & 1.4 & 298.2 & 303.9 & 57.84 & 2.323 \\
\hline
\end{tabular}




\begin{tabular}{|c|c|c|c|c|c|}
29 & 0.014 & 298.2 & 101.3 & 3932 & 2.323 \\
\hline 30 & 0.0002568 & 298.2 & 101.3 & 3932 & 5491 \\
\hline 31 & 0.000133 & 312.2 & 101.3 & 274.7 & 0.8442 \\
\hline
\end{tabular}

Table 18. Annual system productions

\begin{tabular}{|l|l|r|}
\hline Product & Unit & \multicolumn{1}{c|}{ Values } \\
\hline $\mathbf{W}_{\text {net, }, \text { system }}$ & GJ/year & 1.0751 \\
\hline $\mathbf{Q}_{\text {cooling }}$ & GJ/year & 1.04 \\
\hline $\mathbf{V}_{\mathrm{PW}}$ & $\mathrm{m}^{3} /$ year & 18106.8 \\
\hline $\mathbf{m}_{\mathrm{NaCl}}$ & Ton/year & 3.838 \\
\hline $\mathbf{m}_{\mathrm{H} \mathbf{2}}$ & Ton/year & 7.396 \\
\hline
\end{tabular}

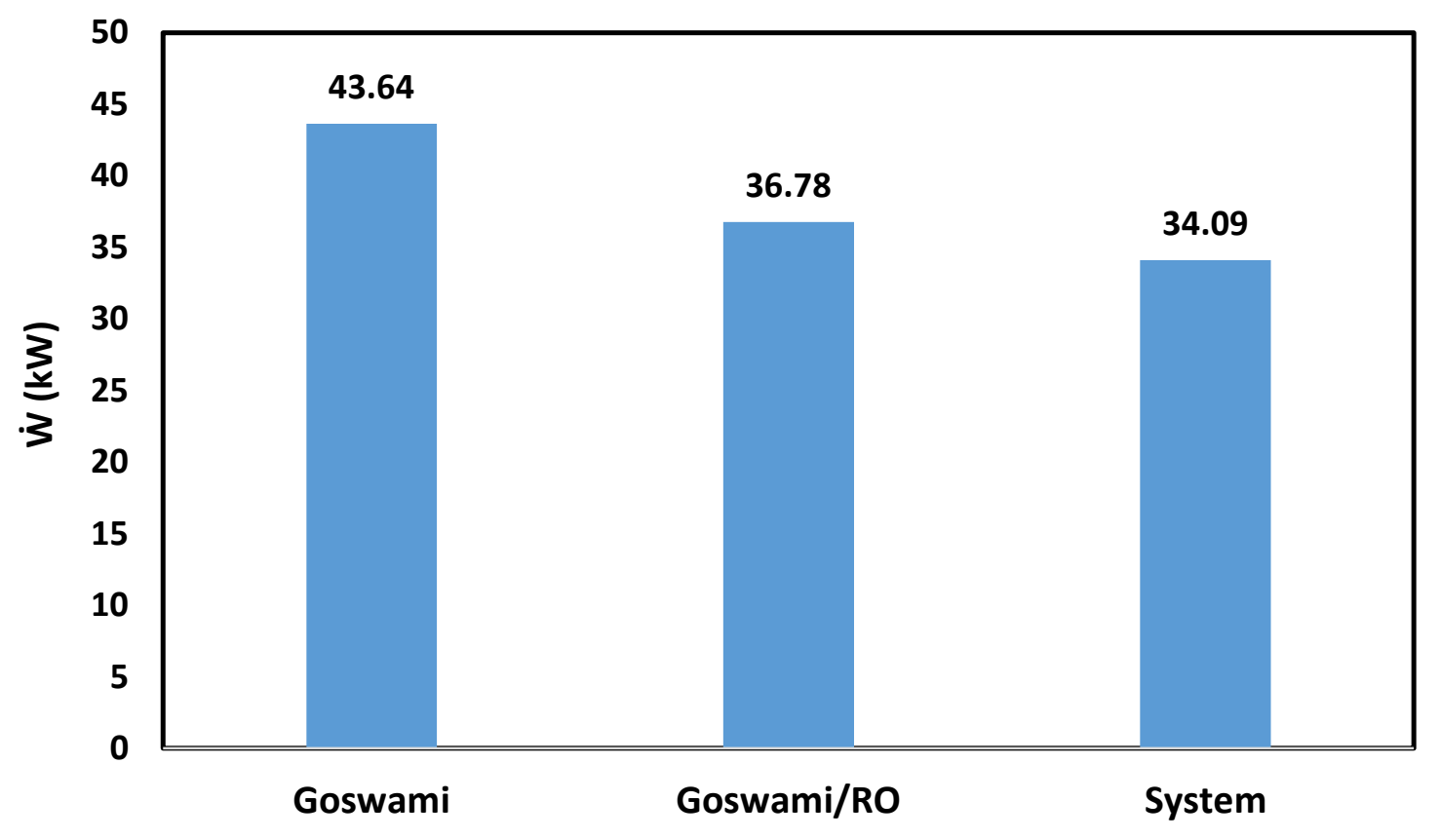

Figure 3. System power production in three configurations (Goswami, Goswami/RO, Goswami/RO/NaClO(system)) 


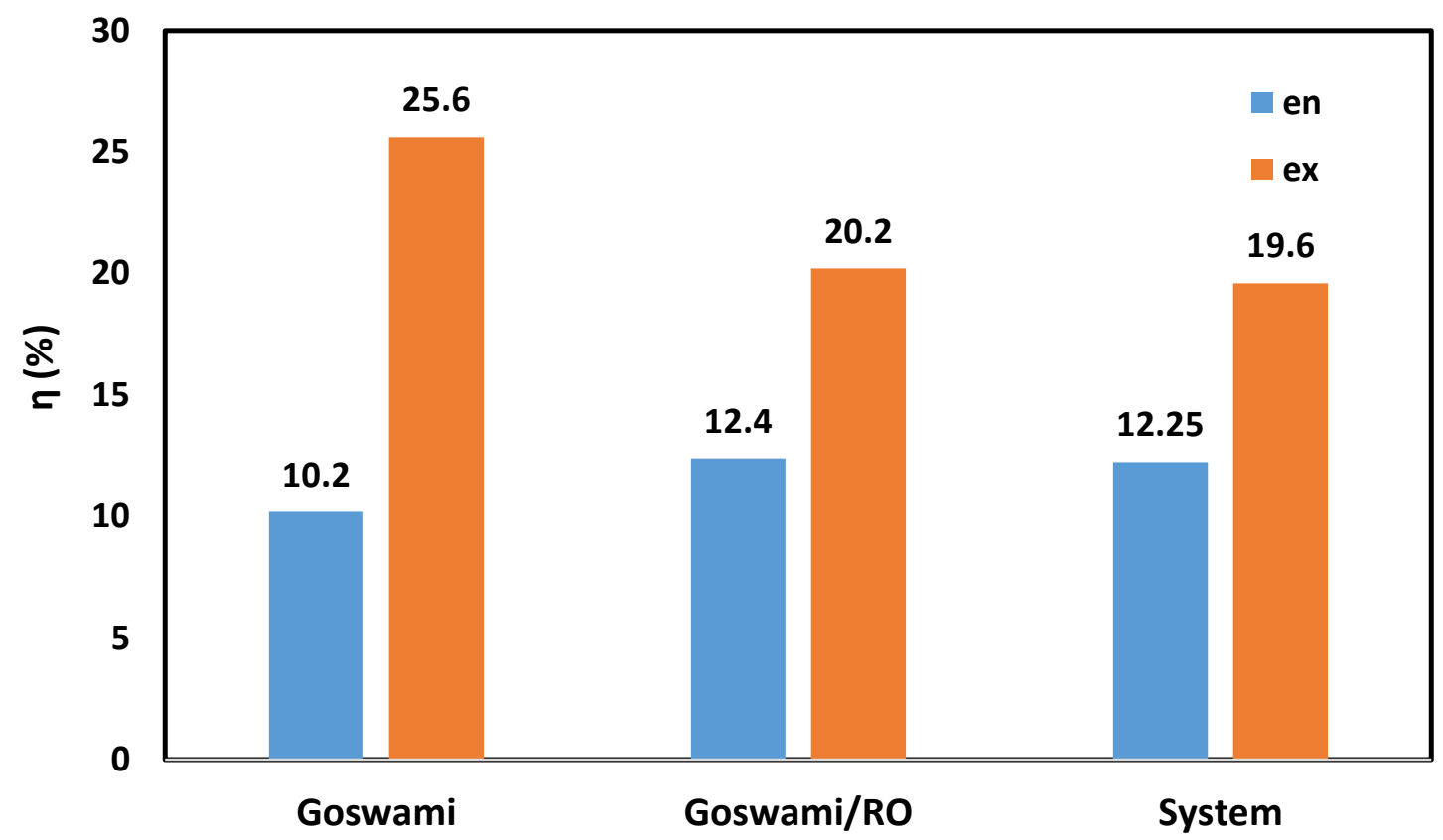

Figure 4. Energy and exergy efficiencies for three configurations (Goswami, Goswami/RO, global system)

Figure 5 shows the share of the exergy destruction rate for each subsystem. The maximum value is related to the Goswami cycle $(87.31 \%)$. This is because this subsystem has the highest number of components and it operates at a temperature which is much higher than the two other subsystems. The RO plant has $11.04 \%$ of the total system exergy destruction rate. The reason is that the RO system operates at temperature $\left(25^{\circ} \mathrm{C}\right)$ near the dead state $\left(15^{\circ} \mathrm{C}, 101.3 \mathrm{kPa}\right)$. Furthermore, this system has a lower number of components than the Goswami cycle. The lowest portion of the total exergy destruction rate is related to the $\mathrm{NaClO}$ plant (1.65\%). The reason is that the mass flow rate of the brine water flowing through the $\mathrm{NaClO}$ plant is low. Similar to the $\mathrm{RO}$ system, this plant operates near the dead state. In general, the addition of these two sub-systems does not induce much exergy destruction on the system. 


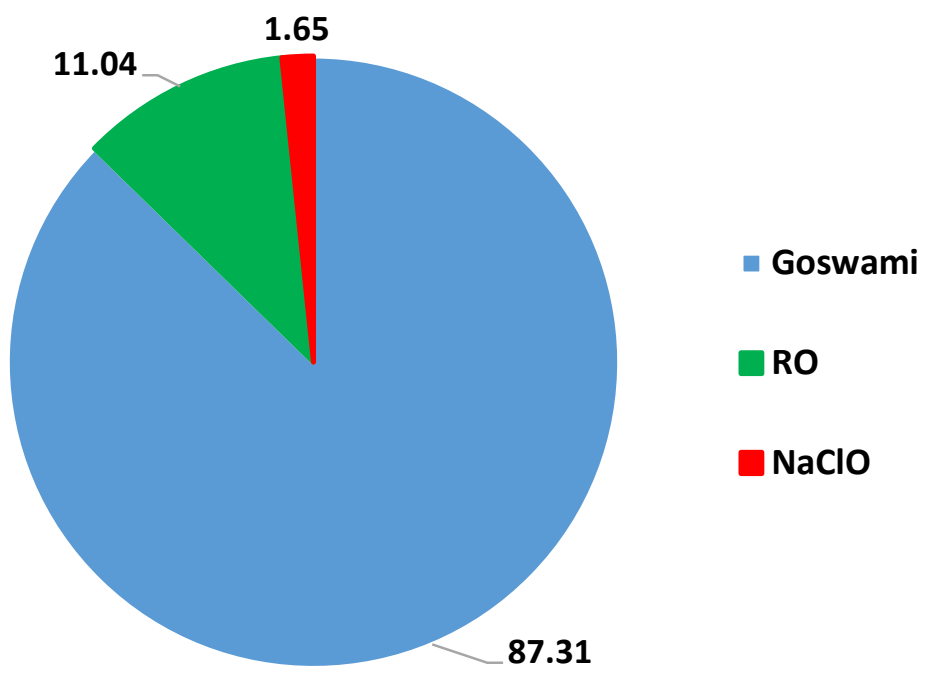

Figure 5. Share of the exergy destruction rate for each subsystem

\subsection{Economic Analysis Results}

Figure 6 shows the Net Present Value (NPV) from the Goswami, Goswami/RO, and total system, respectively. The NPV for the Goswami cycle is 0.826 million US dollars. Adding the RO system to the Goswami cycle is not beneficial considering this factor, because it decreases the NPV from 0.826 to 0.6 million US dollars. It means that the extra cost imposed on the system is higher than the product costs during the lifetime of this system. However, adding the $\mathrm{NaClO}$ plant is beneficial since the value of the NPV increased significantly from 0.6 to 3.1 (higher than five times). Unlike the RO system, in this case, the production benefits (salt and hydrogen) of the $\mathrm{NaClO}$ plant during the lifetime is higher than the initial cost. So, it can be concluded that producing $\mathrm{NaClO}$ and $\mathrm{H}_{2}$ is beneficial from the economic point of view. 


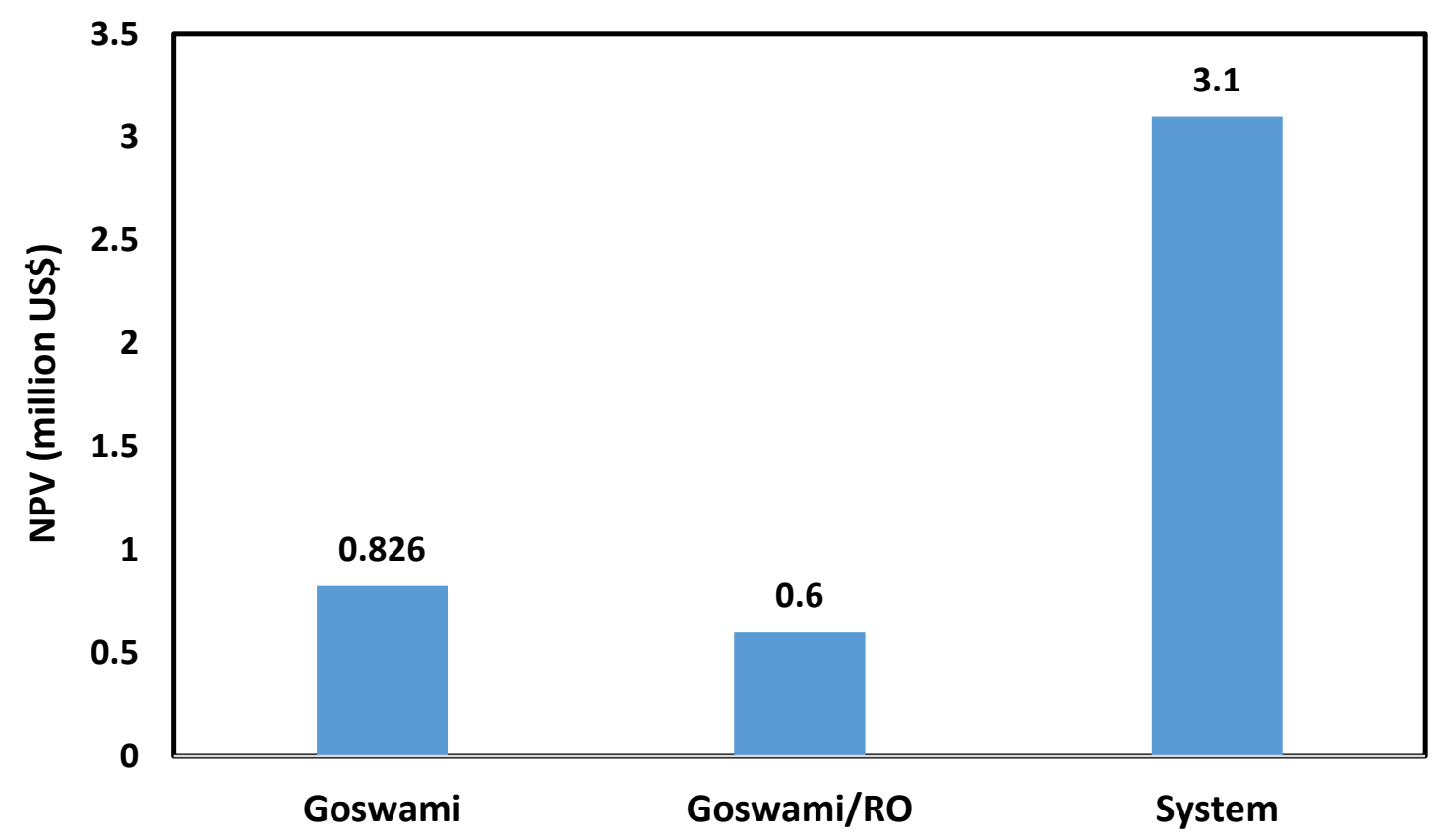

Figure 6. The NPV from the Goswami, Goswami/RO, and total system

The values of the Payback Period (PP) and Simple Payback Period (SPP) are shown in Figure 7. Adding the RO system to the Goswami cycle increases the PP and SPP from 4.26 and 3.95 years to 8.86 and 7.68 years, respectively. But adding the $\mathrm{NaClO}$ plant decreases these values. In general, the total system PP and SPP (2.7 and 2.56 years) are lower than the Goswami cycle and combination of Goswami and RO.

Figure 8 shows the internal rate of return for the Goswami, Goswami/RO, and the total system. By adding the RO system to the Goswami cycle, the IRR is reduced from 0.25 to 0.12 . This reduction is not appropriate. Adding the $\mathrm{NaClO}$ plant to Goswami/RO system compensates this reduction (0.12 to 0.39$)$.

From the economic analysis, it is clear that the $\mathrm{RO}$ system should be combined with the $\mathrm{NaClO}$ plant to bring more benefit to the system. 


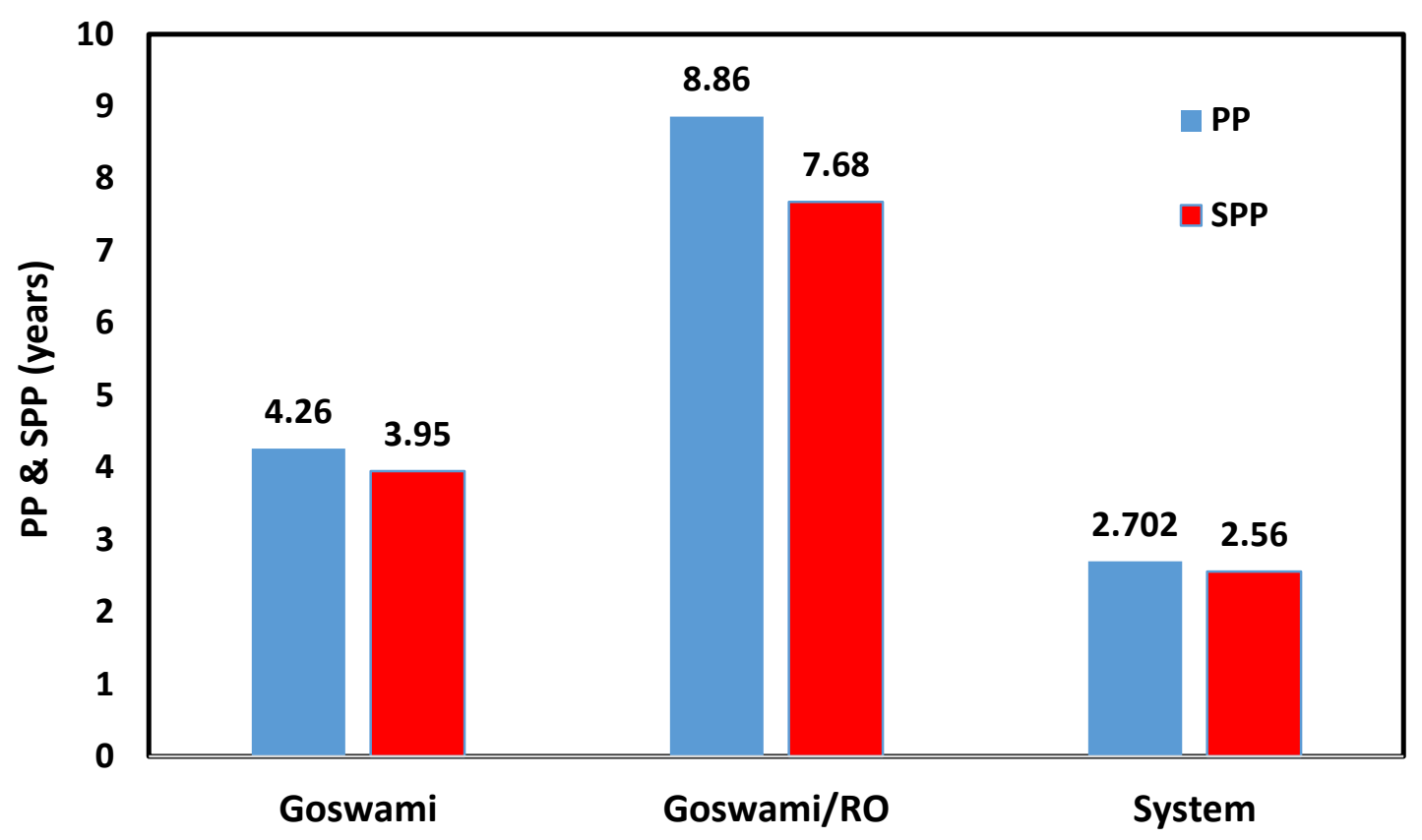

Figure 7. Values of PP and SPP for the Goswami, Goswami/RO, and the total system

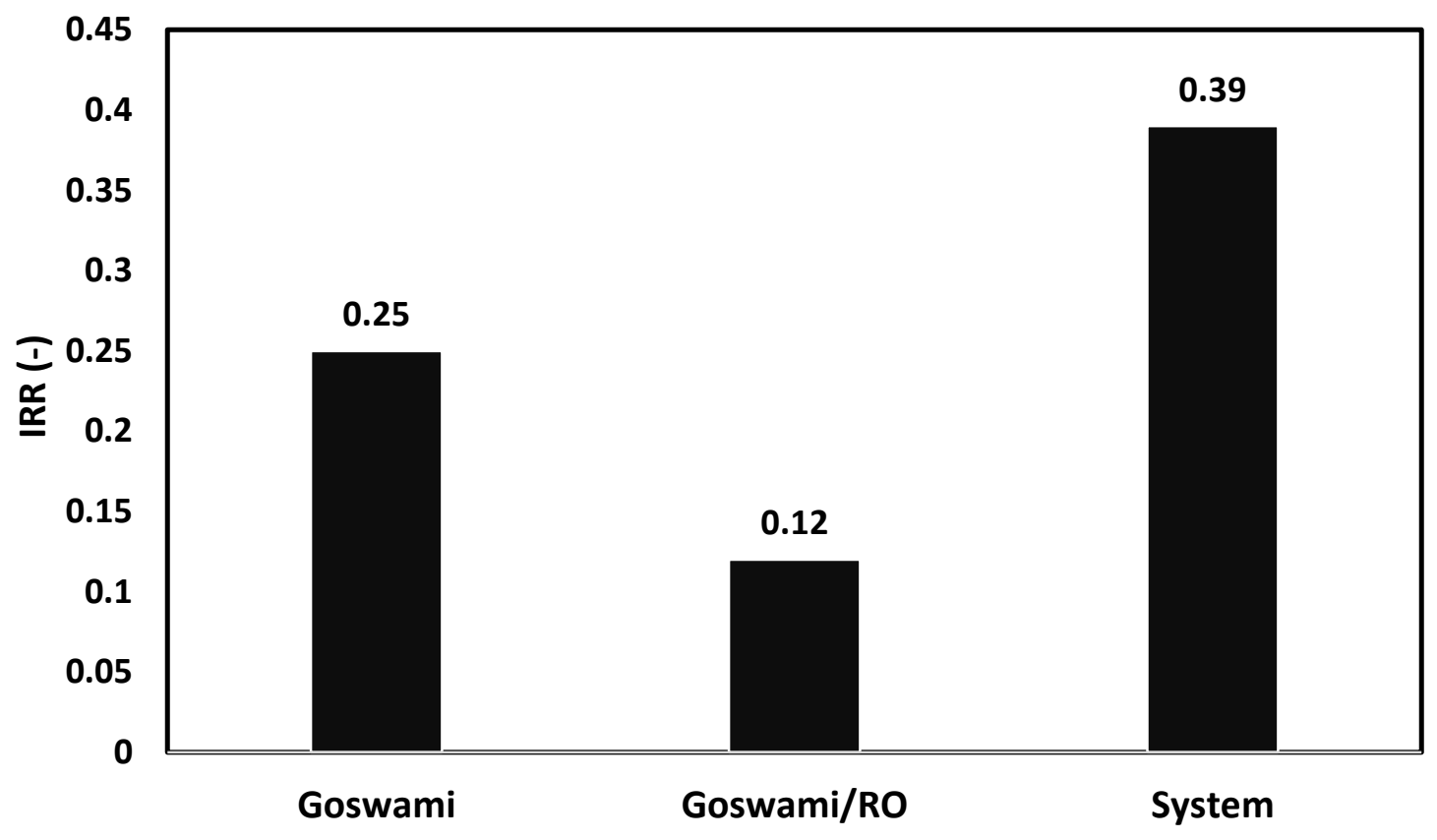

Figure 8. Internal rate of return for the Goswami, Goswami/RO, and the total system 


\subsection{Exergoenvironmental Analysis Results}

Figure 9 shows three exergoenvironmental factors (exergoenvironment $\left(\mathrm{f}_{\mathrm{ei}}\right)$, environmental damage effectiveness $\left(\theta_{e i}\right)$, and exergy stability $\left(\mathrm{f}_{\mathrm{es}}\right)$ ) for three configurations (Goswami, Goswami/RO, and total system), respectively.

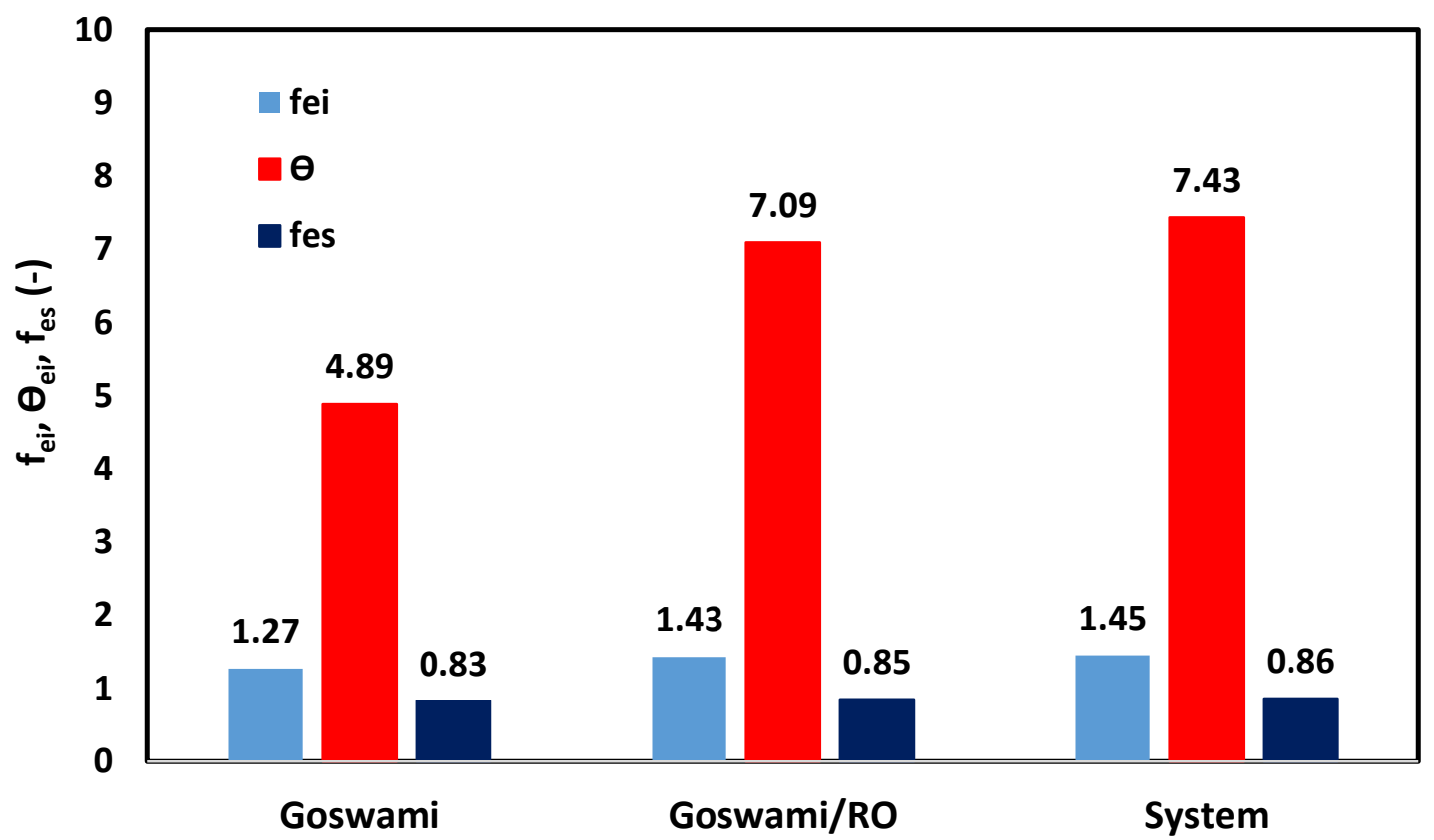

Figure 9. Exergoenvironment $\left(\mathrm{f}_{\mathrm{ei}}\right)$, environmental damage effectiveness $\left(\theta_{e i}\right)$, and exergy stability ( $\left.\mathrm{f}_{\mathrm{es}}\right)$ ) factors for three configurations (Goswami, Goswami/RO, and total system)

The exergoenvironment factor $\left(\mathrm{f}_{\mathrm{ei}}\right)$ increases by adding the $\mathrm{RO}$ and $\mathrm{NaClO}$ plant. If equation 35 is considered, it is clear that the denominator of this equation is the same for all three configurations, since in all three states, the energy resource is geothermal energy. However, the numerator of this equation is increased and each system added to the Goswami cycle has an exergy destruction rate. The trend of the environmental damage effectiveness factor $\left(\theta_{e i}\right)$ is similar to the exergoenvironmental factor $\left(\mathrm{f}_{\mathrm{ei}}\right)$, since the exergy efficiency of the system does not improve by adding the $\mathrm{RO}$ and $\mathrm{NaClO}$ plants. Thus, this factor is increased due to higher exergy destruction rate and lower exergy efficiency.

The exergy stability factor is increased from 0.83 to 0.85 and 0.86 , by adding the $\mathrm{RO}$ and $\mathrm{NaClO}$ systems to the Goswami cycle. It means that the exergy stability factor for Goswami, Goswami/RO, and the total system are $0.83,0.85$, and 0.86 , respectively. This increase is however 
not considerable. Considering the related equation (equation 36), it can be concluded that the amount of exergy destruction rate added to the Goswami cycle is higher than the output exergy of the added system. It means that the output exergy of the $\mathrm{RO}$ and $\mathrm{NaClO}$ system cannot compensate for the exergy destruction produced in these systems.

\subsection{Environmental Analysis Results}

As mentioned before in the environment section, four scenarios are considered for environmental evaluations.

Figure 10 shows the amount of $\mathrm{CO}_{2}, \mathrm{SO}_{2}, \mathrm{NO}_{x}$ produced by the four scenarios if producing the same amount of electrical power generated by the proposed system in this work. The maximum amount of pollution is related to carbon dioxide $\left(\mathrm{CO}_{2}\right)$. The highest amount of $\mathrm{CO}_{2}$ is related to the third scenario (coal-fired power plant) and the minimum amount of $\mathrm{CO}_{2}$ is related to the fourth scenario (gas turbine with heat recovery boiler and back-pressure steam turbine). Similar to $\mathrm{CO}_{2}$, the maximum and minimum amounts of $\mathrm{NO}_{\mathrm{x}}$ are related to the third and fourth scenarios.

The first and fourth scenarios do not exhibit any sulfur dioxide production. The maximum amount of $\mathrm{SO}_{2}$ is related to the third scenario.

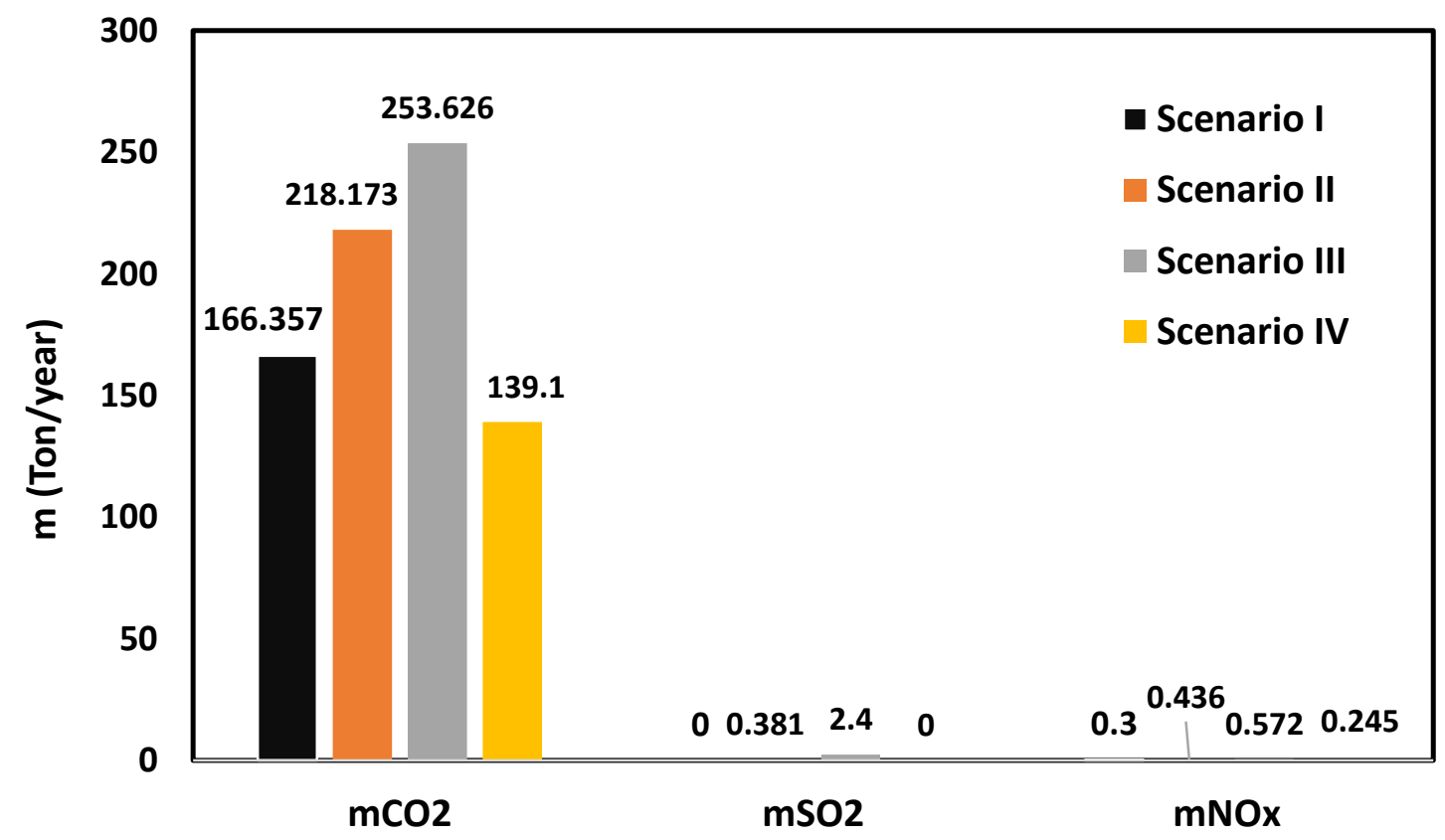

Figure 10. Amount of $\mathrm{CO}_{2}, \mathrm{SO}_{2}, \mathrm{NO}_{\mathrm{x}}$ produced in the four scenarios 
As mentioned before, if the social cost of air pollutions generated by the four scenarios is considered in the economic investigation, due to the absence of air pollution produced by the proposed system in this work, the economic factors (NPV, PP, SPP, IRR) are changed considerably.

Figure 11 shows the amount of NPV if the social cost of air pollution by each scenario is considered. The third scenario displays the maximum amount of NPV, since this scenario generates the maximum amount of air pollution in comparison with other scenarios.

Assuming that the same electrical power of the proposed system is produced by the third scenario and considering the social cost of air pollution, the NPV is changed from 3.1 million US\$ to 3.58 million US\$. If the first, second, and fourth scenarios are considered, this value is changed to 3.17, 3.28 , and 3.17 million US\$, respectively. It can be concluded that by inserting the social cost of air pollution, the multigeneration system powered by renewable energy is more beneficial.

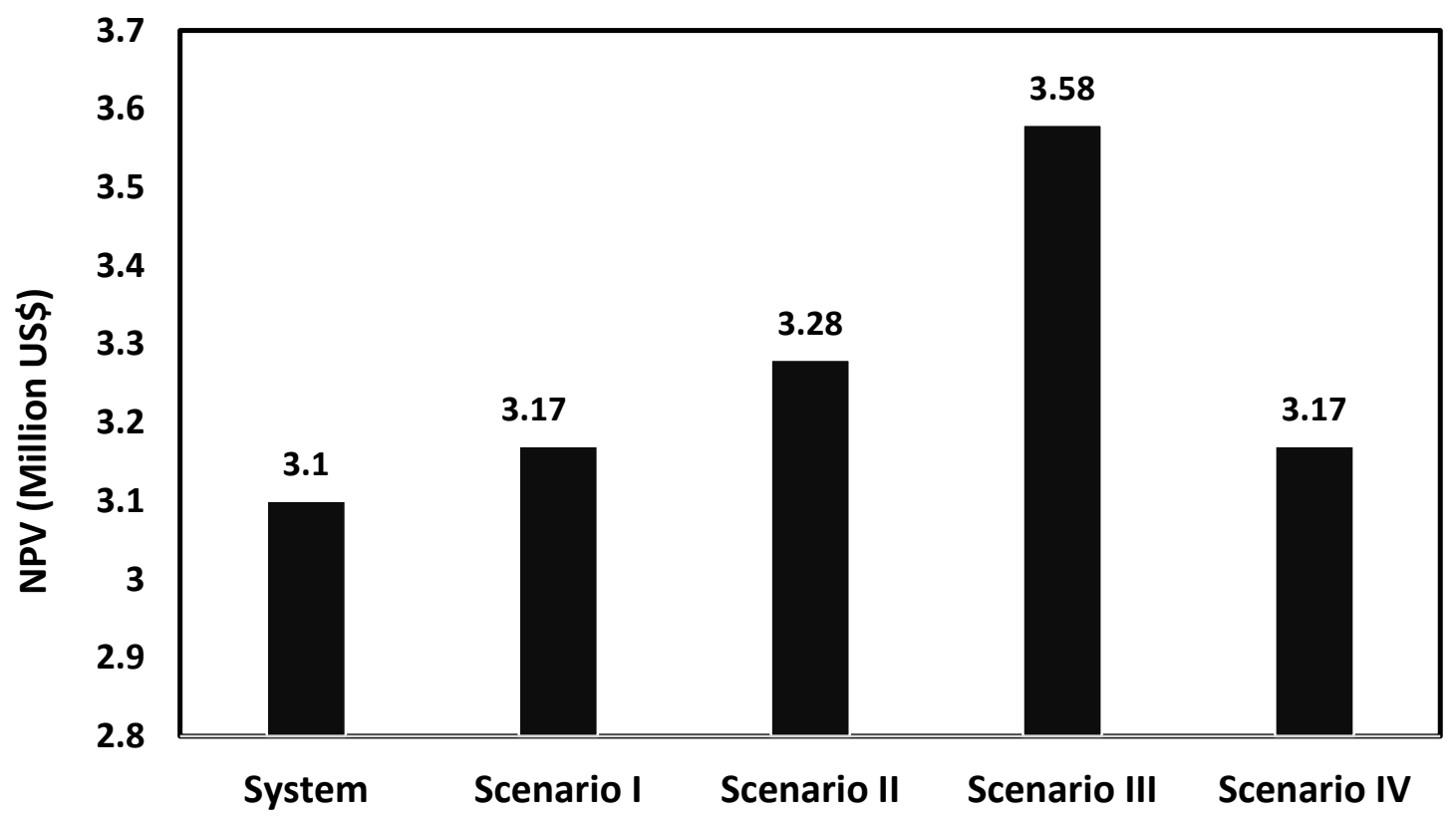

Figure 11. Amount of NPV considering the social cost of air pollution by the four scenarios

Figure 12 shows the comparison of PP and SPP between the system and scenarios I to IV when these scenarios produce the same amount of electrical power. By considering the social cost of air pollution, the amounts of PP and SPP are reduced. For example, if the third scenario is considered, 
the amount of PP and SPP are reduced from 2.7 and 2.56 years to 2.32 and 2.2 years, respectively. The various amounts of the IRR for the system and four scenarios are shown in Figure 13. The same results can be observed in this figure too. By considering the social cost of air pollution, this factor is improved from 0.39 to $0.41,0.42,0.45$, and 0.41 for the first to fourth scenario, respectively. The maximum amount of IRR is related to the third scenario that relies on the coal power plant with the highest air pollution impact.

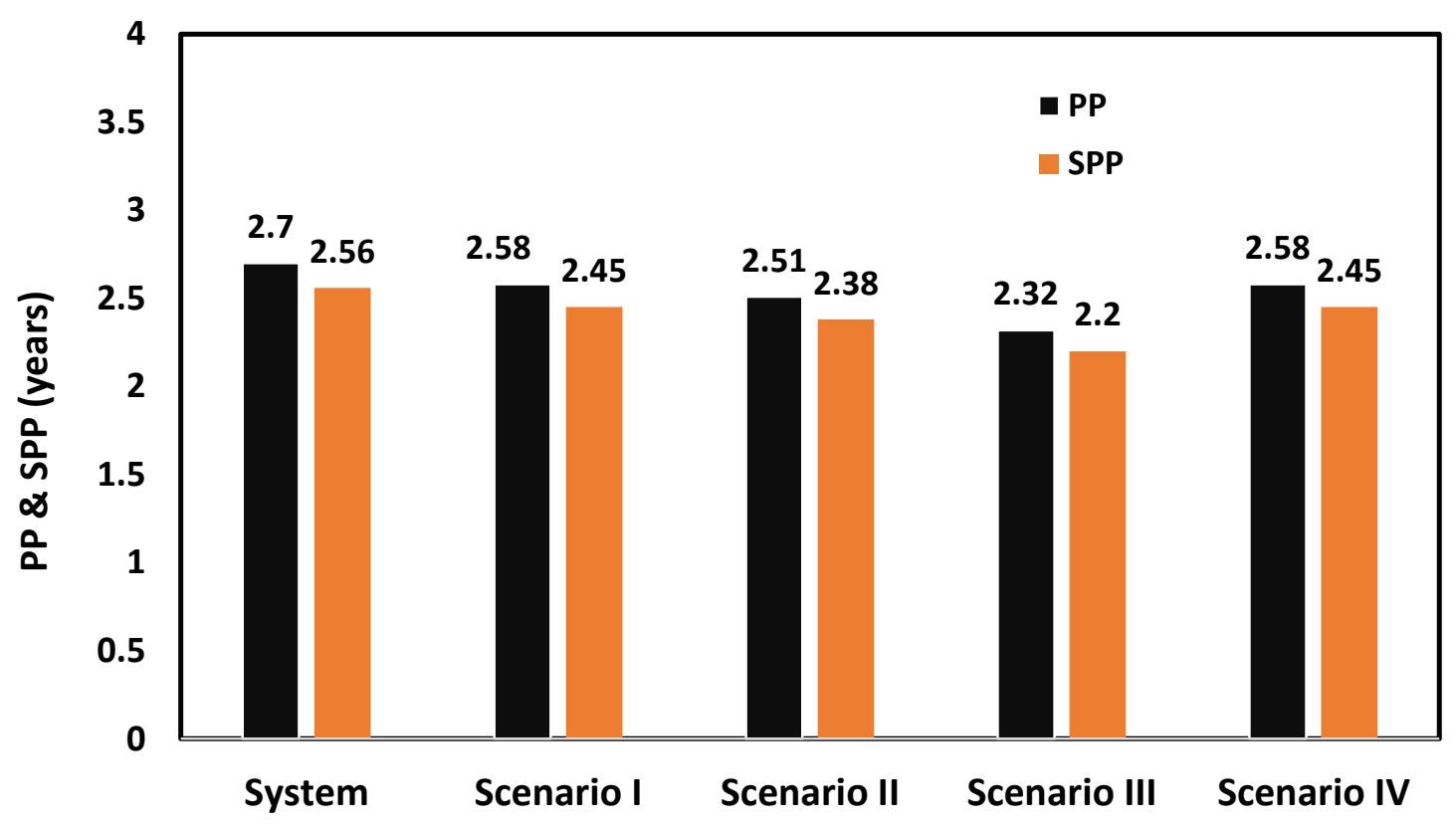

Figure 12. Comparison of PP and SPP between the system and scenarios I to IV 


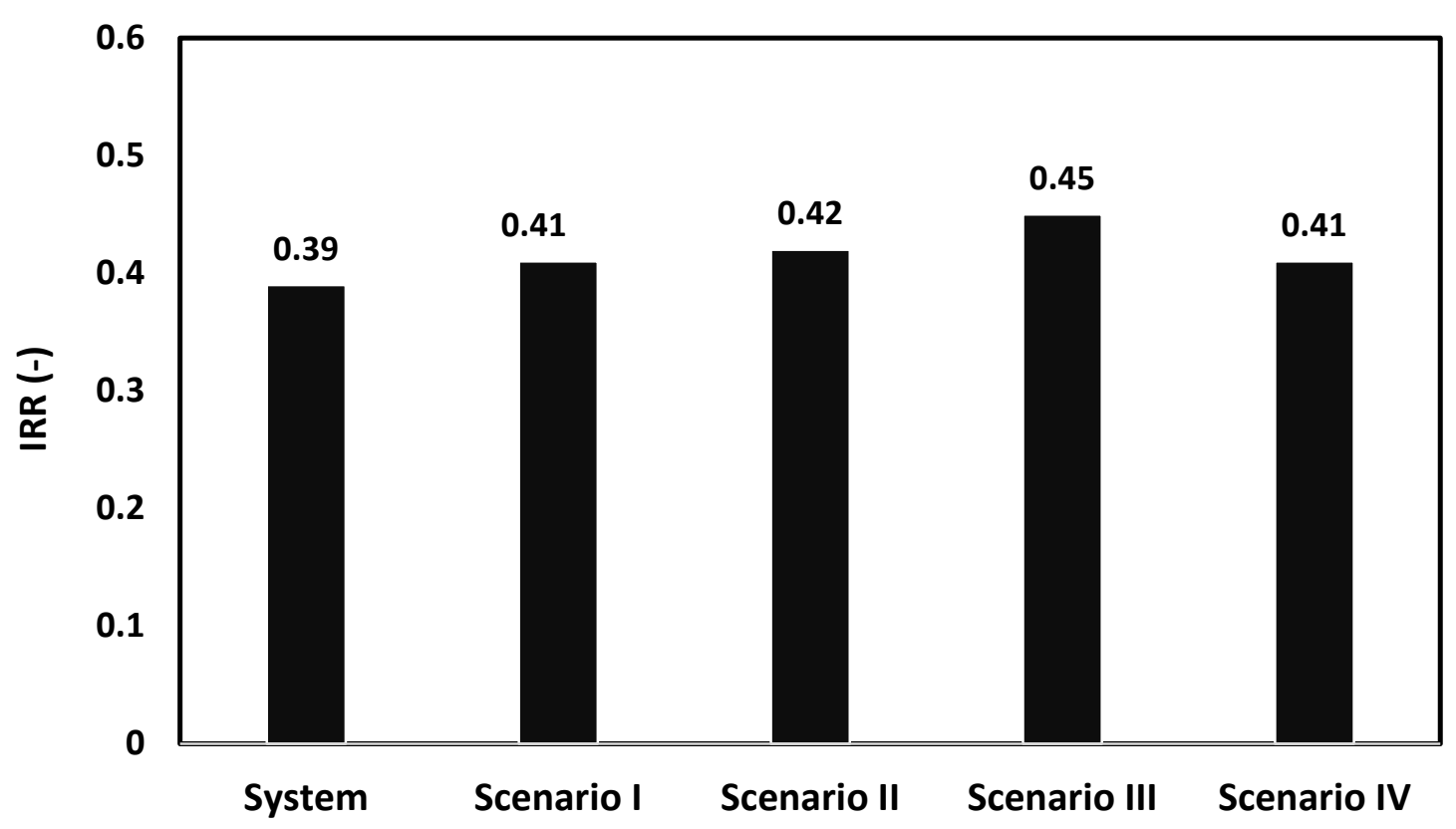

Figure 13. IRR for the system and four scenarios

In general, it can be concluded that if the social cost of air pollution or other sources of pollution is considered in the economic evaluation of the renewable energy powered systems, such multigeneration systems are more economical.

\section{Conclusion}

This study investigated a combined cogeneration system including the combined power and cooling system (Goswami cycle), Reverse Osmosis (RO), and $\mathrm{NaClO}$ production plant. The products of this system are electrical and cooling energy, potable water, hydrogen, and $\mathrm{NaClO}$ (salt).

The energy, exergy, economic, exergoenvironmental, and environmental analyses were conducted in this work to assess all of the aspects of this system. For the environmental analysis and establishment of a relationship between environmental pollutions and economics, the social cost of air pollution was considered. In this regard, four scenarios were defined. It is assumed the same amount of electrical power is produced by the non-renewable energy resource power production systems. These systems are gas turbines with natural gas and gas oil fuels, coal fired steam power plants, and natural gas fueled gas turbines with heat recovery boiler and backpressure steam turbine. 
The air pollutions generated by these systems are estimated by typical data existing in literature. By considering these social costs as benefits for this proposed system due to the absence of air pollution produced during the operation time, the environmental effect can be highlighted.

Summly, the main results of this research are as follows:

- This system produces $1.075 \mathrm{GJ} /$ year electrical energy, 1.04 GJ/year cooling energy, $18106.8 \mathrm{~m}^{3} /$ year potable water, 7.396 Ton/year hydrogen, and 3.838 Ton/year salt are produced annually.

- The system energy efficiency for the Goswami, Goswami/RO, and the total system are equal to $10.2 \%, 12.4 \%$, and $12.25 \%$, respectively.

- The system exergy efficiency for the Goswami, Goswami/RO, and the total system are equal to $25.6 \%, 20.2 \%$, and $19.6 \%$, respectively.

- The share of the exergy destruction rate for the Goswami cycle, $\mathrm{RO}$, and $\mathrm{NaClO}$ plant are $87.3 \%, 11.04 \%$, and $1.65 \%$, respectively.

- The system NPV, PP, SPP, IRR are equal to 3.1 million US\$, 2.7 years, 2.56 years, and 0.39 , respectively.

- The $\mathrm{f}_{\mathrm{ei}}, \Theta_{\mathrm{ei}}, \mathrm{f}_{\mathrm{es}}$ for the total system are $1.45,7.43$, and 0.86 , respectively.

- Adding the $\mathrm{NaClO}$ plant to the system is appropriate from economic point of view.

- By considering the social cost of air pollution in economic evaluation, the renewable energy resource multi-generation systems can be more economical.

\section{Nomenclature}

\section{Abbreviation}

Definition

AFC

ASR

CPVT

DHW

ED

ESC

FC

FGPP
Ammonia fuel cell

Absorption refrigeration

Concentrated Photovoltaics/Thermal

Domestic Hot Water

Electrodialysis, Electrolyzer

Evacuated Solar Collector

Fuel Cell

Flash-Binary Geothermal Power Plant 


\begin{tabular}{|c|c|c|}
\hline GO & \multicolumn{2}{|c|}{ Gas Oil } \\
\hline HDH & \multicolumn{2}{|c|}{ Humidification-Dehumidification unit } \\
\hline KC & \multicolumn{2}{|c|}{ Kalina Cycle } \\
\hline LCOE & \multicolumn{2}{|c|}{ Levelized Cost of Electricity } \\
\hline LCOW & \multicolumn{2}{|c|}{ Levelized Cost of water } \\
\hline MD & \multicolumn{2}{|c|}{ Membrane Distillation } \\
\hline MED & \multicolumn{2}{|c|}{ Multi-Effect Distillation } \\
\hline MSF & \multicolumn{2}{|c|}{ Multi-Stage Flash Distillation } \\
\hline NG & \multicolumn{2}{|c|}{ Natural Gas } \\
\hline ORC & \multicolumn{2}{|c|}{ Organic Rankin Cycle } \\
\hline PCM & \multicolumn{2}{|c|}{ Phase Change Material } \\
\hline PEMFC & \multicolumn{2}{|c|}{ Proton Exchange Membrane Fuel Cell } \\
\hline PRO & \multicolumn{2}{|c|}{ Pressure Retarded Osmosis } \\
\hline PTC & \multicolumn{2}{|c|}{ Parabolic Through Collector } \\
\hline PV & \multicolumn{2}{|c|}{ Photovoltaic } \\
\hline RHE & \multicolumn{2}{|c|}{ Refrigeration Heat Exchanger } \\
\hline RHX & \multicolumn{2}{|c|}{ Recovery Heat Exchanger } \\
\hline RO & \multicolumn{2}{|c|}{ Reverse Osmosis } \\
\hline SC & \multicolumn{2}{|c|}{ Steam Cycle } \\
\hline SD & \multicolumn{2}{|c|}{ Solar Dish } \\
\hline SSE & \multicolumn{2}{|c|}{ Single Stage Evaporator } \\
\hline SUCP & \multicolumn{2}{|c|}{ Sum Unit Cost of Product } \\
\hline TES & \multicolumn{2}{|c|}{ Thermal Energy Storage } \\
\hline TGOR & \multicolumn{2}{|c|}{ Trigeneration-based Gain-Output-Ratio } \\
\hline VC & \multicolumn{2}{|c|}{ Vapor-Compression Evaporation } \\
\hline Symbols & & Definition \\
\hline $\mathbf{A}$ & $\mathrm{m}^{2}$ & Area \\
\hline $\mathrm{C}_{\mathbf{0}}$ & US\$ & System investment cost \\
\hline $\mathrm{C}_{\mathrm{ei}}$ & - & Exergoenvironmental impact coefficient \\
\hline $\mathbf{C}_{\mathbf{n}}$ & US\$ & $\begin{array}{l}\text { System investment cost in the specific year } \\
\text { with considering inflation rate }\end{array}$ \\
\hline $\mathbf{C F}$ & US\$ & Cogeneration annual income \\
\hline D & $\mathrm{m}$ & Diameter \\
\hline e & $\mathrm{kJ} / \mathrm{kg}$ & Specific exergy \\
\hline$\dot{\mathrm{E}}$ & $\mathrm{kW}$ & Exergy rate \\
\hline
\end{tabular}




\begin{tabular}{|c|c|c|}
\hline $\mathbf{f}_{\mathbf{e i}}$ & - & Exrgroenvironment factor \\
\hline $\mathbf{f}_{\text {es }}$ & - & Exergy stability factor \\
\hline $\mathbf{F}_{\mathbf{t}}$ & - & Correction factor \\
\hline $\mathbf{g}$ & $\mathrm{m} / \mathrm{s}^{2}$ & Gravitational acceleration \\
\hline $\mathbf{h}$ & $\mathrm{kJ} / \mathrm{kg}$ & Specific enthalpy \\
\hline IRR & - & Internal rate of return \\
\hline $\mathbf{k}$ & US $\$ / \mathrm{kWh}$ & Products specific cost \\
\hline $\mathbf{K}$ & US\$ & $\begin{array}{l}\text { Investment and installation cost of each } \\
\text { subsystem }\end{array}$ \\
\hline $\mathbf{K}_{\mathbf{w}}$ & $1 / \mathrm{K}$ & Water permeability coefficient \\
\hline$\dot{\mathbf{m}}$ & $\mathrm{kg} / \mathrm{s}$ & Mass flow rate \\
\hline $\mathbf{N}$ & Years & Lifetime of the project \\
\hline NPV & US\$ & Net Present Value \\
\hline $\mathbf{P}$ & $\mathrm{kPa}$ & Pressure \\
\hline PP & Years & Payback Period \\
\hline$\dot{\mathbf{Q}}$ & $\mathrm{kW}$ & Heat transfer rate \\
\hline $\mathbf{r}$ & - & Discount factor \\
\hline $\mathbf{R}$ & $\mathrm{kJ} / \mathrm{kmoleK}$ & Global gas constant \\
\hline $\mathbf{R R}$ & - & Recovery ratio \\
\hline $\mathbf{s}$ & $\mathrm{kJ} / \mathrm{kgK}$ & Specific entropy \\
\hline SPP & Years & Simple Payback Period \\
\hline $\mathbf{T}$ & ${ }^{\circ} \mathrm{C} / \mathrm{K}$ & Temperature \\
\hline $\mathbf{U}$ & $\mathrm{W} / \mathrm{m}^{2} \mathrm{~K}$ & Overall heat transfer coefficient \\
\hline $\mathbf{V}$ & $\mathrm{m} / \mathrm{s}, \mathrm{m}^{3}$ & Velocity, Volume \\
\hline$\dot{\mathbf{W}}$ & $\mathrm{kW}$ & Work transfer rate \\
\hline$x$ & - & Concentration of salt, Mass fraction \\
\hline$X$ & - & Ammonia mass ratio \\
\hline $\mathbf{y}$ & - & Mole fraction \\
\hline $\mathbf{Y}$ & $\mathrm{US} \$ / \mathrm{kWh}, \mathrm{US} \$ / \mathrm{kg}$ & Annual capacity of system productions \\
\hline $\mathbf{z}$ & $\mathrm{m}$ & Height, Depth of geothermal well \\
\hline \multicolumn{3}{|c|}{ Greek Symbols } \\
\hline$\eta$ & - & Polythrophic efficiency \\
\hline$\Delta \pi$ & $\mathrm{kPa}$ & Net-pressure membrane \\
\hline$\theta_{\mathbf{e i}}$ & - & Environmental damage effectiveness factor \\
\hline
\end{tabular}




$\begin{array}{lll}\theta_{\text {eii }} & \text { Subscripts } & \\ \text { 0 } & \text { Dead state } \\ \text { BW } & \text { Brain water } \\ \text { ch } & \text { Chemical } \\ \text { D } & \text { Destruction } \\ \text { en } & \text { Energy } \\ \text { ex } & \text { Exergy } \\ \text { f } & \text { Formation } \\ \text { i } & \text { Species } \\ \text { in } & \text { Inlet } \\ \text { out } & \text { Outlet } \\ \text { m } & \text { Membrane } \\ \text { P } & \text { Product, Pump } \\ \text { PW } & \text { Potable water } \\ \text { R } & \text { Reactant } \\ \text { Sep } & \text { Seperator } \\ \text { SW } & \text { Seawater } \\ \text { T } & \text { Turbine }\end{array}$

\section{Exergoenvironmental impact}

\section{Definition}

Dead state

Brain water

ical

Formation

Species

Potable water

Reactant

Seperator

ate

\section{References}

[1] The Global Risks Report 2019, weforum.org/reports/the-global-risks-report-2019 [Access 03.06.2020], in, 2019.

[2] M. Ehyaei, S. Hakimzadeh, N. Enadi, P. Ahmadi, Exergy, economic and environment (3E) analysis of absorption chiller inlet air cooler used in gas turbine power plants, International Journal of Energy Research, 36 (2012) 486-498.

[3] M.M. Mekonnen, A.Y. Hoekstra, Four billion people facing severe water scarcity, Science Advances, 2 (2016) e1500323.

[4] How do we prevent today's water crisis becoming tomorrow's catastrophe? weforum.org/agenda/2017/03/building-freshwater-resilience-to-anticipate-and-address-water-crises [Access 03.06.2020]

in, 2017.

[5] C.J. Vörösmarty, P. Green, J. Salisbury, R.B. Lammers, Global Water Resources: Vulnerability from Climate Change and Population Growth, Science, 289 (2000) 284-288.

[6] R.G. Raluy, L. Serra, J. Uche, A. Valero, Life-cycle assessment of desalination technologies integrated with energy production systems, Desalination, 167 (2004) 445-458.

[7] A.D. Khawaji, J.-M. Wie, Potabilization of desalinated water at Madinat Yanbu Al-Sinaiyah, Desalination, 98 (1994) 135-146. 
[8] M. Al-Shammiri, M. Safar, Multi-effect distillation plants: state of the art, Desalination, 126 (1999) 4559.

[9] O.K. Buros, The ABCs of Desalting, in, International Desalination AssociationTopsfield, Massachusetts, USA, 2000.

[10] The Desalting and Water Treatment Membrane Manual: A Guide to Membranes for Municipal Water Treatment, Water Treatment Technology Program, Report No. 1, usbr.gov/research/dwpr/reportpdfs/report001.pdf [Access 03.06.2020], in, the United States Department of the Interior, Bureau of Reclamation, Denver Office, Research and Laboratory Services Division, Applied Sciences

Branch (R-93-15), 1993.

[11] A.D. Khawaji, I.K. Kutubkhanah, J.-M. Wie, Advances in seawater desalination technologies, Desalination, 221 (2008) 47-69.

[12] T. Xu, lon exchange membranes: State of their development and perspective, Journal of Membrane Science, 263 (2005) 1-29.

[13] J.E. Miller, Review of Water Resources and Desalination Technologies in, Sandia National Laboratories Albuquerque, New Mexico 87185 and Livermore, California 945502003.

[14] M.I.M. Shatat, Solar water desalination, in,

, School of Engineering, Durham University, UK, 2008.

[15] Water Desalination Technologies in the ESCWA Member Countries, in, United Nations. Economic and Social Commission for Western Asia, 2001.

[16] M.A. Darwish, H. El-Dessouky, The heat recovery thermal vapour-compression desalting system: A comparison with other thermal desalination processes, Applied Thermal Engineering, 16 (1996) 523-537.

[17] S. Karellas, A. Schuster, A. Leontaritis, Influence of supercritical ORC parameters on plate heat exchanger design, Applied Thermal Engineering, s 33-34 (2012) 70-76.

[18] S.A. Kalogirou, Seawater desalination using renewable energy sources, Progress in Energy and Combustion Science, 31 (2005) 242-281.

[19] W. Rice, D.S.C. Chau, Freeze desalination using hydraulic refrigerant compressors, Desalination, 109 (1997) 157-164.

[20] H. Chen, L. Wang, Chapter 8 - Posttreatment Strategies for Biomass Conversion, in: H. Chen, L. Wang (Eds.) Technologies for Biochemical Conversion of Biomass, Academic Press, Oxford, 2017, pp. 197-217.

[21] M.W. Shahzad, M. Burhan, L. Ang, K.C. Ng, Energy-water-environment nexus underpinning future desalination sustainability, Desalination, 413 (2017) 52-64.

[22] H. Mahmoudi, N. Ghaffour, M.F. Goosen, J. Bundschuh, Renewable energy technologies for water desalination, CRC Press, 2017.

[23] M.A. Ehyaei, A. Ahmadi, M. El Haj Assad, M.A. Rosen, Investigation of an integrated system combining an Organic Rankine Cycle and absorption chiller driven by geothermal energy: Energy, exergy, and economic analyses and optimization, Journal of Cleaner Production, 258 (2020) 120780.

[24] M. El Haj Assad, E. Bani-Hani, M. Khalil, Performance of geothermal power plants (single, dual, and binary) to compensate for LHC-CERN power consumption: comparative study, Geothermal Energy, 5 (2017) 17.

[25] H. Kianfard, S. Khalilarya, S. Jafarmadar, Exergy and exergoeconomic evaluation of hydrogen and distilled water production via combination of PEM electrolyzer, RO desalination unit and geothermal driven dual fluid ORC, Energy Conversion and Management, 177 (2018) 339-349.

[26] L. Ozgener, A. Hepbasli, I. Dincer, Energy and exergy analysis of the Gonen geothermal district heating system, Turkey, Geothermics, 34 (2005) 632-645.

[27] M.A. Abdelkareem, M. El Haj Assad, E.T. Sayed, B. Soudan, Recent progress in the use of renewable energy sources to power water desalination plants, Desalination, 435 (2018) 97-113. 
[28] V. Zare, A comparative thermodynamic analysis of two tri-generation systems utilizing low-grade geothermal energy, Energy Conversion and Management, 118 (2016) 264-274.

[29] O. Siddiqui, I. Dincer, A new solar and geothermal based integrated ammonia fuel cell system for multigeneration, International Journal of Hydrogen Energy, (2020).

[30] A. Mohammadi, M. Mehrpooya, Energy and exergy analyses of a combined desalination and CCHP system driven by geothermal energy, Applied Thermal Engineering, 116 (2017) 685-694.

[31] B. Ghorbani, A. Ebrahimi, M. Moradi, M. Ziabasharhagh, Energy, exergy and sensitivity analyses of a novel hybrid structure for generation of Bio-Liquefied natural Gas, desalinated water and power using solar photovoltaic and geothermal source, Energy Conversion and Management, 222 (2020) 113215.

[32] P. Behnam, A. Arefi, M.B. Shafii, Exergetic and thermoeconomic analysis of a trigeneration system producing electricity, hot water, and fresh water driven by low-temperature geothermal sources, Energy Conversion and Management, 157 (2018) 266-276.

[33] A. Colmenar-Santos, E. Palomo-Torrejón, F. Mur-Pérez, E. Rosales-Asensio, Thermal desalination potential with parabolic trough collectors and geothermal energy in the Spanish southeast, Applied Energy, 262 (2020) 114433.

[34] T. Gholizadeh, M. Vajdi, H. Rostamzadeh, A new trigeneration system for power, cooling, and freshwater production driven by a flash-binary geothermal heat source, Renewable Energy, 148 (2020) 31-43.

[35] S.A. Makkeh, A. Ahmadi, F. Esmaeilion, M.A. Ehyaei, Energy, exergy and exergoeconomic optimization of a cogeneration system integrated with parabolic trough collector-wind turbine with desalination, Journal of Cleaner Production, 273 (2020) 123122.

[36] A. Shekari Namin, H. Rostamzadeh, P. Nourani, Thermodynamic and thermoeconomic analysis of three cascade power plants coupled with RO desalination unit, driven by a salinity-gradient solar pond, Thermal Science and Engineering Progress, 18 (2020) 100562.

[37] A. Mouaky, A. Rachek, Thermodynamic and thermo-economic assessment of a hybrid solar/biomass polygeneration system under the semi-arid climate conditions, Renewable Energy, 156 (2020) 14-30.

[38] B. Ghorbani, R. Shirmohammadi, M. Mehrpooya, Development of an innovative cogeneration system for fresh water and power production by renewable energy using thermal energy storage system, Sustainable Energy Technologies and Assessments, 37 (2020) 100572.

[39] F. Calise, F.L. Cappiello, R. Vanoli, M. Vicidomini, Economic assessment of renewable energy systems integrating photovoltaic panels, seawater desalination and water storage, Applied Energy, 253 (2019) 113575.

[40] G. Filippini, M.A. Al-Obaidi, F. Manenti, I.M. Mujtaba, Design and economic evaluation of solarpowered hybrid multi effect and reverse osmosis system for seawater desalination, Desalination, 465 (2019) 114-125.

[41] N. Sezer, M. Koç, Development and performance assessment of a new integrated solar, wind, and osmotic power system for multigeneration, based on thermodynamic principles, Energy Conversion and Management, 188 (2019) 94-111.

[42] Q. Li, L.-J. Beier, J. Tan, C. Brown, B. Lian, W. Zhong, Y. Wang, C. Ji, P. Dai, T. Li, P. Le Clech, H. Tyagi, X. Liu, G. Leslie, R.A. Taylor, An integrated, solar-driven membrane distillation system for water purification and energy generation, Applied Energy, 237 (2019) 534-548.

[43] F. Xu, Analysis of a novel combined thermal power and cooling cycle using ammonia-water mixtures as a working fluid, in, University of Florida, 1997.

[44] G. Tamm, D.Y. Goswami, S. Lu, A.A. Hasan, Novel Combined Power and Cooling Thermodynamic Cycle for Low Temperature Heat Sources, Part I: Theoretical Investigation, Journal of Solar Energy Engineering, 125 (2003) 218-222.

[45] D.Y. Goswami, F. Xu, Analysis of a New Thermodynamic Cycle for Combined Power and Cooling Using Low and Mid Temperature Solar Collectors, Journal of Solar Energy Engineering, 121 (1999) 91-97. 
[46] G. Tamm, D.Y. Goswami, S. Lu, A.A. Hasan, Theoretical and experimental investigation of an ammonia-water power and refrigeration thermodynamic cycle, Solar Energy, 76 (2004) 217-228.

[47] A. Behzadi, E. Gholamian, P. Ahmadi, A. Habibollahzade, M. Ashjaee, Energy, exergy and exergoeconomic (3E) analyses and multi-objective optimization of a solar and geothermal based integrated energy system, Applied Thermal Engineering, 143 (2018) 1011-1022.

[48] S.M. Alirahmi, S. Rahmani Dabbagh, P. Ahmadi, S. Wongwises, Multi-objective design optimization of a multi-generation energy system based on geothermal and solar energy, Energy Conversion and Management, 205 (2020) 112426.

[49] R. Yargholi, H. Kariman, S. Hoseinzadeh, M. Bidi, A. Naseri, Modeling and advanced exergy analysis of integrated reverse osmosis desalination with geothermal energy, Water Supply, 20 (2020) 984-996.

[50] B.H. Gebreslassie, G. Guillén-Gosálbez, L. Jiménez, D. Boer, Design of environmentally conscious absorption cooling systems via multi-objective optimization and life cycle assessment, Applied Energy, 86 (2009) 1712-1722.

[51] A. Al-Zahrani, J. Orfi, Z. Al-Suhaibani, B. Salim, H. Al-Ansary, Thermodynamic Analysis of a Reverse Osmosis Desalination Unit with Energy Recovery System, Procedia Engineering, 33 (2012) 404-414.

[52] A. Ahmadi, M. El Haj Assad, D.H. Jamali, R. Kumar, Z.X. Li, T. Salameh, M. Al-Shabi, M.A. Ehyaei, Applications of geothermal organic Rankine Cycle for electricity production, Journal of Cleaner Production, 274 (2020) 122950.

[53] E. Ghasemian, M.A. Ehyaei, Evaluation and optimization of organic Rankine cycle (ORC) with algorithms NSGA-II, MOPSO, and MOEA for eight coolant fluids, International Journal of Energy and Environmental Engineering, 9 (2018) 39-57.

[54] M.A. Ehyaei, A. Ahmadi, M.A. Rosen, A. Davarpanah, Thermodynamic Optimization of a Geothermal Power Plant with a Genetic Algorithm in Two Stages, Processes, 8 (2020) 1277.

[55] A. Bejan, Advanced engineering thermodynamics, John Wiley \& Sons, 2016.

[56] G. Demirkaya, R.V. Padilla, A. Fontalvo, M. Lake, Y.Y. Lim, Thermal and Exergetic Analysis of the Goswami Cycle Integrated with Mid-Grade Heat Sources, Entropy, 19 (2017) 416.

[57] F. Xu, D.Y. Goswami, S.S. Bhagwat, A combined power/cooling cycle, Energy, 25 (2000) 233-246.

[58] D.Y. Goswami, F. Xu, Analysis of a new thermodynamic cycle for combined power and cooling using low and mid temperature solar collectors, (1999).

[59] A. Naseri, M. Bidi, M.H. Ahmadi, Thermodynamic and exergy analysis of a hydrogen and permeate water production process by a solar-driven transcritical $\mathrm{CO} 2$ power cycle with liquefied natural gas heat sink, Renewable Energy, 113 (2017) 1215-1228.

[60] H.T. El-Dessouky, H.M. Ettouney, Fundamentals of salt water desalination, Elsevier, 2002.

[61] A. Lazzaretto, G. Tsatsaronis, SPECO: a systematic and general methodology for calculating efficiencies and costs in thermal systems, Energy, 31 (2006) 1257-1289.

[62] A. Bejan, G. Tsatsaronis, M. Moran, Thermal Design and Optimization John Wiley and Sons, Inc. New York, (1996).

[63] E. Bellos, S. Pavlovic, V. Stefanovic, C. Tzivanidis, B.B. Nakomcic-Smaradgakis, Parametric analysis and yearly performance of a trigeneration system driven by solar-dish collectors, International Journal of Energy Research, 43 (2019) 1534-1546.

[64] C. Tzivanidis, E. Bellos, K.A. Antonopoulos, Energetic and financial investigation of a stand-alone solarthermal Organic Rankine Cycle power plant, Energy conversion and management, 126 (2016) 421-433.

[65] H. Nami, I.S. Ertesvåg, R. Agromayor, L. Riboldi, L.O. Nord, Gas turbine exhaust gas heat recovery by organic Rankine cycles (ORC) for offshore combined heat and power applications-Energy and exergy analysis, Energy, 165 (2018) 1060-1071.

[66] M. Mishra, P.K. Das, S. Sarangi, Optimum design of crossflow plate-fin heat exchangers through genetic algorithm, (2004). 
[67] A. Ahmadi, D.H. Jamali, M.A. Ehyaei, M.E.H. Assad, Energy, exergy, economic and exergoenvironmental analyses of gas and air bottoming cycles for production of electricity and hydrogen with gas reformer, Journal of Cleaner Production, 259 (2020) 120915.

[68] https://www.flinnsci.com/sodium-chloride-laboratory-grade-500-g/s0063/ [Access 03.06.2020], in, 2020.

[69] H. Nami, E. Akrami, Analysis of a gas turbine based hybrid system by utilizing energy, exergy and exergoeconomic methodologies for steam, power and hydrogen production, Energy Conversion and Management, 143 (2017) 326-337.

[70] J.C.E.P. Carlos Eymel Campos Rodrígueza, César Rodríguez Sotomontea, Marcio Lemea, Osvaldo J. Venturinia, Electo E. Silva Loraa, Vladimir Melián Cobasa, Daniel Marques dos Santosb, Fábio R. Lofrano Dottoc, Vernei Giallucad, Exergetic and economic analysis of Kalina cycle for low temperature geothermal sources in Brazil, in: The 25th international conference on efficiency, cost, optimization, simulation and environmental impact of energy systems, Perugia, Italy, 2012, pp. 1-13.

[71] P. Dorj, Thermoeconomic Analysis of a New Geothermal Utilization CHP Plant in Tsetserleg, in: Department of Mechanical and Industrial Engineering, Iceland, University of Iceland, 2005.

[72] A. Bejan, G. Tsatsaronis, M.J. Moran, Thermal design and optimization, John Wiley \& Sons, 1995.

[73] K. Bahlouli, R. Khoshbakhti Saray, N. Sarabchi, Parametric investigation and thermo-economic multiobjective optimization of an ammonia-water power/cooling cycle coupled with an $\mathrm{HCCl}$ (homogeneous charge compression ignition) engine, Energy, 86 (2015) 672-684.

[74] L.S. Vieira, J.L. Donatelli, M.E. Cruz, Exergoeconomic improvement of a complex cogeneration system integrated with a professional process simulator, Energy Conversion and Management, 50 (2009) 19551967.

[75] R. Turton, R.C. Bailie, W.B. Whiting, J.A. Shaeiwitz, Analysis, synthesis and design of chemical processes, Pearson Education, 2008.

[76] J.L. Silveira, C.E. Tuna, Thermoeconomic analysis method for optimization of combined heat and power systems. Part I, Progress in Energy and Combustion Science, 29 (2003) 479-485.

[77] M. Ameri, P. Ahmadi, A. Hamidi, Energy, exergy and exergoeconomic analysis of a steam power plant: A case study, International Journal of Energy Research, 33 (2009) 499-512.

[78] M.L. Koenraad F. Beckers, TimothyJ. Reber, Brian J. Anderson,Michal C. Moore, Jefferson W. Tester, Introducing geophires V1.0 software package for estimating levelized cost of eletricity and/or heat from enhanced geothermal systems, in: Thirty-EighthWorkshop on Geothermal Reservoir Engineering, Stanford University, Stanford, California, USA, 2012.

[79] Y. Du, L. Xie, J. Liu, Y. Wang, Y. Xu, S. Wang, Multi-objective optimization of reverse osmosis networks by lexicographic optimization and augmented epsilon constraint method, Desalination, 333 (2014) 66-81.

[80] Establishment of cost functions for construction of various types of public water services assets in Portugal, in, 2003.

[81] Sodium hypochlorite production plant of chlorination system chemical production plant alibaba.com/product-detail/Sodium-hypochlorite-production-plant-of-chlorination_60489161719 [Access 03.06.2020], in, 2020.

[82] L. Pierobon, T.-V. Nguyen, U. Larsen, F. Haglind, B. Elmegaard, Multi-objective optimization of organic Rankine cycles for waste heat recovery: Application in an offshore platform, Energy, 58 (2013) 538-549.

[83] S.J. Zarrouk, M.H. Purnanto, Geothermal steam-water separators: Design overview, Geothermics, 53 (2015) 236-254.

[84] T. Shafer, Calculating Inflation Factors for Cost Estimates, in, City of Lincoln Transportation and Utilities Project Delivery.

[85] Statista, Global inflation rate compared to previous year, in.

[86] S. Edalati, M. Ameri, M. Iranmanesh, H. Tarmahi, M. Gholampour, Technical and economic assessments of grid-connected photovoltaic power plants: Iran case study, Energy, 114 (2016) 923-934. 
[87] T.A. Ratlamwala, I. Dincer, M.A. Gadalla, Comparative environmental impact and sustainability assessments of hydrogen and cooling production systems, in: Causes, Impacts and Solutions to Global Warming, Springer, 2013, pp. 389-408.

[88] T.A. Ratlamwala, I. Dincer, B.V. Reddy, Exergetic and Environmental Impact Assessment of an Integrated System for Utilization of Excess Power from Thermal Power Plant, in: Causes, Impacts and Solutions to Global Warming, Springer, 2013, pp. 803-824.

[89] A. Midilli, I. Dincer, Development of some exergetic parameters for PEM fuel cells for measuring environmental impact and sustainability, International Journal of Hydrogen Energy, 34 (2009) 3858-3872. [90] J.S. David Birchby, Sally Whiting,, M. Vedrenne, Air Quality damage cost update 2019, in, 2019.

[91] S. Karkour, Y. Ichisugi, A. Abeynayaka, N. Itsubo, External-Cost Estimation of Electricity Generation in G20 Countries: Case Study Using a Global Life-Cycle Impact-Assessment Method, Sustainability, 12 (2020) 2002.

[92] Combined Heat and Power (CHP) Developers Guides in, United Kingdom Government Department of Energy \& Climate Change 2009.

[93] H.I. Emara, Nutrient salts, inorganic and organic carbon contents in the waters of the Persian Gulf and the Gulf of Oman, Journal of the Persian Gulf, 1 (2010) 33-44.

[94] FILMTEC ${ }^{\text {TM }}$ Membranes How to Evaluate the Active Membrane Area of Seawater Reverse Osmosis Elements, dupont.com/content/dam/dupont/amer/us/en/water-solutions/public/documents/en/45D01504-en.pdf [Access 03.06.2020] (2015). 


\section{Response to reviewers' comments}

\section{Dear Respectful Editor-in-Chief}

\section{Journal: Desalination}

The revision-1 of paper entitled" Energy, Exergy, Economic, Exergoenvironmental, and Environmental analyses of a Multigeneration System to Produce Electricity, Cooling, Potable Water, Hydrogen and Sodium-Hypochlorite" is attached. All the changes are highlighted by yellow color in the revised manuscript.

\section{Reviewer\#1:}

1) This is a comprehensive study utilizing renewable energy (geothermal energy) with conventional membrane process (reverse osmosis). Electrolysis process (sodium hypochlorite) production was also considered. Energy, exergy, economic, exergoenvironmental, and environmental analyses of this multigeneration system was investigated for the production of electricity, cooling, potable water, hydrogen and sodiumhypochlorite. Since this work represent a potential use of such system, I recommend its publication with minor modifications and moderate priorities.

Ans. Thank you for your support.

2) The justification of utilizing such a combine system is not shown; i.e the added values (benefits, contribution) of each process on the integrated system are not described.

Ans. Thank you for your valuable comment. The following paragraph has been added to the paper as shown below:

The benefits of the proposed desalination system are varied and the key products are potable water (as main needs for humanity), hydrogen (a key clean fuel for the transportation sector), electrical and cooling energy (as needs for residential, commercial, and industrial applications), and sodium-hypochlorite (a valuable co-product).

\section{Reviewer \#2:}

1) In this paper very useful information on $5 \mathrm{E}$ analyses of a Multigeneration System to Produce Electricity, Cooling, Potable Water, Hydrogen and Sodium Hypochlorite is provided.

Ans. Thank you for your support.

2) Introduction is very general without any data. Author should provide information on Electricity, Cooling, Potable Water, Hydrogen and Sodium Hypochlorite production, demand and estimated gap in neat future. 
Ans. Thank you for your valuable comment. More details about the Electricity, Cooling, Potable Water, Hydrogen and Sodium Hypochlorite production have been added in the Introduction, and are highlighted in the text.

3) They only highlighted partially water production information in introduction and totally ignored other parameters mentioned in the title.

Ans. The introduction has been extended to address the other parameters mentioned in the title in addition to water production. A review of different multigeneration systems coupled with renewable energy has been included.

4) The desalination related information presented in the literature is also not latest, they should read latest developments and present accordingly. They can read following article for latest desalination processes related information.

* Muhammad Wakil Shahzad, Muhammad Burhan, Li Ang and Kim Choon Ng, Energy-waterenvironment nexus underpinning future desalination sustainability, Desalination 413 (2017) 5264.

Ans. The literature survey has been updated with different recent references added in the introduction, and the mentioned reference has also been added to the paper as shown below:

Based on a survey carried out by Shahzad et al. [6], the potable water demand will increase up to 60 billion $\mathrm{m}^{3}$ by 2050 . This huge amount of water production can be achieved with different types of desalination systems so that the total energy consumption of desalination systems reaches 75.2 TWh per year. Moreover, it was recommended to improve the thermodynamic efficiency of the desalination systems from $10 \%$ to $25 \%$, develop high flux membrane material for RO system, and design high-efficiency hybrid MED/MSF desalination systems.

5) Table 2 is incomplete. The energy and exergy efficiency is depend on operational parameters those are missing and the current values providing wrong impression about different technologies. For example, geothermal energy efficiency $73 \%$, one can get at 40C?. Author should provide related operational parameters in the table.

Ans. Additional details about different operational conditions of Table 2 are now mentioned in the text highlighted in yellow (introduction section). Furthermore, the summary of previous studies is reported in Table 2. 
6) In section 2.1 author mentioned, After careful investigation of the multi/co-generation systems and different products from them, but in actual they only provided the literature on water production. Not sure why they keep calling it multigeneration system.

Ans. The literature survey for various multigeneration systems now covers the various products in addition to water production. The fourth column in Table 2 specifies the products of each system reviewed in literature. This column is highlighted as shown below:

\begin{tabular}{|c|c|c|c|c|c|c|c|c|}
\hline No. & Energy resource & Components & Products & Analysis & $\begin{array}{c}\text { Energy } \\
\text { efficiency } \\
(\% 0\end{array}$ & $\begin{array}{c}\text { Exergy } \\
\text { efficiency } \\
(\%) \\
\end{array}$ & $\begin{array}{c}\text { Cost of } \\
\text { products }\end{array}$ & Ref \\
\hline 1 & Solar/Geothermal & RO;PEMFC;ASR;AFC;HSR & $\begin{array}{l}\text { Electricity, } \\
\text { Freshwater, } \\
\text { Hydrogen, and } \\
\text { Cooling }\end{array}$ & Energy/Exergy & 42.3 & 21.3 & - & [29] \\
\hline 2 & Geothermal & $\mathrm{KC}, \mathrm{RO}$ & $\begin{array}{c}\text { Electricity, Heating, } \\
\text { Cooling, and } \\
\text { Freshwater }\end{array}$ & Energy/Exergy & - & 38.1 & - & {$[30]$} \\
\hline 3 & Solar/Geothermal & $\begin{array}{c}\text { Biogas system, MED, ORC; } \\
\text { PV }\end{array}$ & $\begin{array}{l}\text { Bio-liquefied natural } \\
\text { gas; Freshwater, } \\
\text { Electricity }\end{array}$ & Energy/Exergy & 73.2 & 76.8 & - & [31] \\
\hline 4 & Geothermal & ORC; ASR; SSE & $\begin{array}{l}\text { Electricity, Hot and } \\
\text { Fresh water }\end{array}$ & $\begin{array}{l}\text { Energy/Exergy/ } \\
\text { Thermoeconomic }\end{array}$ & 34 & 43 & $\begin{array}{c}\mathrm{LCOE}=0.04 \\
\$ / \mathrm{kWh} \\
\mathrm{LCOW}=29.4 \\
\$ / \mathrm{m}^{3}\end{array}$ & {$[32]$} \\
\hline 5 & Solar/Geothermal & PTC; MED & Freshwater & Feasibility study & - & - & - & [33] \\
\hline 6 & Geothermal & FGPP; HDH & Electriciy/Cooling & Energy/Exergy & 46.4 & $\begin{array}{l}\text { TGOR }= \\
0.9275\end{array}$ & - & [34] \\
\hline 7 & Solar/Geothermal & MED; PTC; ORC & $\begin{array}{l}\text { Electricity; Cooling; } \\
\text { Heating; Freshwater; } \\
\text { Absorption Chiller }\end{array}$ & Exergy/Exergoeconomic & - & 63 & $\begin{array}{c}\text { Electricity } \\
\text { exergoeconomic } \\
\text { cost }=0.1475- \\
0.1722 € / \mathrm{kW} \mathrm{h} \\
\text { Chilled water } \\
\text { exergoeconomic } \\
\text { cost }=0.1863- \\
0.1888 € / \mathrm{kW} \\
\text { hex } \\
\text { Cooling water } \\
\text { exergoeconomic } \\
\text { cost }=0.01612- \\
0.01702 € / \mathrm{kW} \\
\text { hex } \\
\text { Freshwater } \\
\text { exergoeconomic } \\
\text { cost }=0.5695- \\
0.6023 € / \mathrm{kW} \\
\text { hex. }\end{array}$ & [34] \\
\hline 8 & Solar/Wind & $\begin{array}{l}\text { PTC; Wind turbine; MED; } \\
\text { RO }\end{array}$ & $\begin{array}{c}\text { Electricity/Fresh } \\
\text { water }\end{array}$ & $\begin{array}{l}\text { Energy/ Exergy/ } \\
\text { Exergoeconomic }\end{array}$ & - & 26.2 & $\begin{array}{c}\text { Fresh water } \\
\text { cost }=3.08 \$ / \mathrm{m}^{3}\end{array}$ & [35] \\
\hline 9 & Solar & Solar Pond; KC; ORC; RO & Electricity/Freshwater & $\begin{array}{l}\text { Thermodynamic/ } \\
\text { Thermoeconomic }\end{array}$ & - & 18 & $\begin{array}{c}\mathrm{SUCP}=101.7 \\
\$ / \mathrm{kWh}\end{array}$ & [36] \\
\hline 10 & Solar/Biomass & & $\begin{array}{c}\text { Electricity/ } \\
\text { Freshwater/, domestic } \\
\text { hot water (DHW) }\end{array}$ & $\begin{array}{l}\text { Thermodynamic/ } \\
\text { Thermoeconomic }\end{array}$ & $\begin{array}{l}11.3- \\
16.3\end{array}$ & $5.3-6$ & $\begin{array}{c}\text { Electricity cost= } \\
0.231 € / \mathrm{kW} \\
\text { Fresh water } \\
\text { cost }=0.86 € / \mathrm{m}^{3} \\
\text { DHW cost }= \\
0.047 € / \mathrm{kW}\end{array}$ & [37] \\
\hline 11 & Solar & SD; PCM; SC; MED & $\begin{array}{l}\text { Electricity; } \\
\text { Freshwater }\end{array}$ & Energy/ Exergy & 28.8 & 52.2 & - & [38] \\
\hline 12 & Solar & PV; RO & $\begin{array}{l}\text { Electricity; } \\
\text { Freshwater }\end{array}$ & Economic & - & - & $\mathrm{PP}=1.3$ years & [39] \\
\hline 13 & Solar & PV; MED; RO & $\begin{array}{c}\text { Electricity; Fresh } \\
\text { water }\end{array}$ & Economic & - & - & $\begin{array}{c}\text { Electricity cost }= \\
0.1 € / \mathrm{kWh} \\
\text { Fresh water } \\
\text { cost }=0.59 € / \mathrm{m}^{3}\end{array}$ & [40] \\
\hline
\end{tabular}




\begin{tabular}{|c|c|c|c|c|c|c|c|c|}
\hline 14 & Solar/Wind & $\begin{array}{l}\text { Wind Turbine; CPVT; TES; } \\
\text { FC; EL; MSF; VCR; PRO }\end{array}$ & $\begin{array}{c}\text { Electricity; } \\
\text { Freshwater; Cooling; } \\
\text { Hydrogen }\end{array}$ & Energy/ Exergy & 73.3 & 30.6 & - & [41] \\
\hline 15 & Solar & ESC; MD & Freshwater & Economic & - & - & $\mathrm{PP}=4$ years & [42] \\
\hline
\end{tabular}

Abbreviations: Reverse Osmosis: RO; Proton Exchange Membrane Fuel Cell: PEMFC; Absorption Refrigeration: ASR; Ammonia Fuel Cell: AFC; Organic Rankin Cycle: ORC; Single Stage Evaporator: SSE; Photovoltaic: PV; Levelized Cost of Electricity: LCOE; Levelized Cost of water: LCOW; Parabolic Through Collector: PTC; Trigeneration-based Gain-Output-Ratio: TGOR; Flash-Binary Geothermal Power Plant: FGPP; HumidificationDehumidification unit: HDH; Kalina Cycle: KC; SUCP: Sum Unit Cost of Product; Domestic Hot Water: DHW; PCM: Phase Change Material; Steam Cycle: SC; Solar Dish: SD; PP: Payback Period; CPVT: Concentrated Photovoltaics/Thermal; TES: Thermal Energy Storage; Electrolyzer: EL; Fuel Cell: FC; Multistage Flash Distillation: MSF; Vapor Compression Refrigeration: VCR; Pressure Retarded Osmosis: PRO; Evacuated Solar Collector: ESC

7) Goswami cycle is not the same as ammonia chiller?, if yes, then it should not be called as innovation.

Ans. The Goswami cycle configuration is different from the ammonia chiller. Also, the main output of the Goswami cycle is electrical and cooling energy production simultaneously while the ammonia chiller only produces cooling energy.

8) Author mentioned, the innovations of this paper are as follows, and the all components/processes mentioned are available in the literature. They should not call it as innovation. The language of manuscript need to address accordingly

Ans. This innovation has been deleted, and the second innovation has been updated as follows:

- Energy, exergy, economic, exergoenvironmmental, and environmental analyses of the multigeneration system to produce electrical, cooling, potable water, hydrogen, and NaClO simultaneously

- Establish a relationship between environmental negative effects and economics by considering the social cost of environmental pollution.

9) In assumptions, they considered geothermal temperature $120 \mathrm{C}$ without any geological information. They should provide geological chart and point out the location of proposed study.

Ans. This assumption has been revised as shown below:

1- The geothermal working fluid pressure, temperature, and mass flow rate are equal to $2 \mathrm{bar}, 120{ }^{\circ} \mathrm{C}$, and $15 \mathrm{~kg} / \mathrm{s}$, respectively. The location of geothermal wells is in the Bandar Abbas city located in the southern of Iran. The type of geothermal resource is hydrothermal.

10) The pressure loss is neglected....considering geothermal and pressure losses neglected is not acceptable in simulation work. It will have very high impact in terms of depth. They should include this factor in simulation instead neglecting it. 
Ans. The neglecting of pressure is related to the Goswami cycle and the RO system. For the geothermal loop, the $3 \%$ pressure loss is considered which is compatible with the following reference:

M.A.Ehyaei, A. Ahmadi, M. El Haj Assad, Marc A. Rosen. Investigation of an integrated system combining an Organic Rankine Cycle and absorption chiller driven by geothermal energy: Energy, exergy, and economic analyses and optimization. Journal of Cleaner Production 258 (2020) 120780.

11) Table 3 is just 1 st law analysis that don't exist in real world. They should include proper hear transfer coefficient and other correlations for ammonia system. For example, https://doi.org/10.1016/j.ijrefrig.2019.04.008 article provide detailed model for ammonia chiller and author should conduct proper analysis.

Ans. For calculating the overall surface area of heat exchangers, the logarithmic method is applied. The $U$ values for various heat exchangers (separator, boiler, heat exchanger, and absorber) are presented in Table 11 of the paper. The following text has been added:

For estimating the surface area of the heat exchanger, the logarithmic method is applied. In this regard, the following equation is considered [81]:

$$
\dot{Q}=U A F_{t} \Delta T_{I n}
$$

where $\dot{Q}, U, A, F_{t}$, and $\Delta T_{I n}$ are the heat transfer rate, overall heat transfer coefficient, surface area, correction factor, and logarithmic mean temperature difference. The overall heat transfer coefficient for various components is shown in Table 10 [50]. The method for estimating the volume of the separator is explained in Ref. [82].

\begin{tabular}{|c|c|c|}
\hline No. & Components & $U\left(W / m^{2} K\right)$ \\
\hline 1 & Separator & 300 \\
\hline 2 & Boiler & 500 \\
\hline 3 & Heat exchanger & 700 \\
\hline 4 & Absorber & 800 \\
\hline
\end{tabular}

12) Similarly, table 4 is also just a 1st law analysis of RO ignoring all losses and proper membrane impact.

Ans. The net pressure throughout the membranes is equal to net pressure of the RO pump that is calculated by equation 11. Since the outlet pressure of the RO pump is very high to allow the seawater flow through the membranes, neglecting the pressure loss is compatible with the real data. The equation is shown below: 
The net pressure of the RO pump is calculated by $[49,56]$ :

$$
\Delta P=\frac{\dot{m}_{P W}}{K_{W} A_{m}}+\Delta \pi
$$

\section{$A_{m}$ is the membrane area.}

13) Table 13 and 14 references are missing.

Ans. The references have been added to both tables as shown below:

Table 13. Four scenarios and air pollution production [91]

Table 14. Input information of the simulation code

\begin{tabular}{|c|c|c|c|}
\hline Parameter & Unit & Value & Ref \\
\hline $\boldsymbol{X}_{\boldsymbol{I}}$ & - & 0.53 & {$[45]$} \\
\hline $\boldsymbol{X}_{4}$ & - & 0.94 & {$[45]$} \\
\hline $\boldsymbol{X}_{5}$ & - & 0.99 & {$[45]$} \\
\hline$\dot{\boldsymbol{m}}_{\boldsymbol{1}}$ & $\mathrm{kg} / \mathrm{s}$ & 0.4 & - \\
\hline $\boldsymbol{T}_{\boldsymbol{1}}$ & $\mathrm{K}$ & 280 & {$[45]$} \\
\hline $\boldsymbol{T}_{5}$ & $\mathrm{~K}$ & 348 & {$[45]$} \\
\hline $\boldsymbol{T}_{7}$ & $\mathrm{~K}$ & 278 & {$[45]$} \\
\hline $\boldsymbol{P}_{1}$ & $\mathrm{kPa}$ & 202.6 & {$[45]$} \\
\hline $\boldsymbol{P}_{2}$ & $\mathrm{kPa}$ & 3039 & {$[45]$} \\
\hline $\boldsymbol{x}_{16}$ & $\mathrm{mg} / \mathrm{l}$ & 40200 & {$[92]$} \\
\hline $\boldsymbol{x}_{27}$ & $\mathrm{mg} / \mathrm{l}$ & 150 & {$[92]$} \\
\hline $\boldsymbol{A}_{\boldsymbol{m}}$ & $\mathrm{m}{ }^{2}$ & 35.3 & {$[93]$} \\
\hline $\mathbf{R R}$ & - & 0.3 & {$[56]$} \\
\hline$\dot{\boldsymbol{m}}_{16}$ & $\mathrm{~kg} / \mathrm{s}$ & 2 & - \\
\hline
\end{tabular}

14) Author's results Fig 4 is contradicting with Table 3 . Their results shows geothermal system energetic and exergetic efficiency $12 \%$ and 19\% respectively. In Table 3 its was quoted as $34 \%$ and $43 \%$ respectively. They have to check their model and results carefully. 
Ans. The Table 3 in the paper only shows the related equation. The figure 4 shows values of energy and exergy efficiencies.

15) Fig 10 legends are missing.

Ans. The legend has been added to the Figure 10 as shown below:

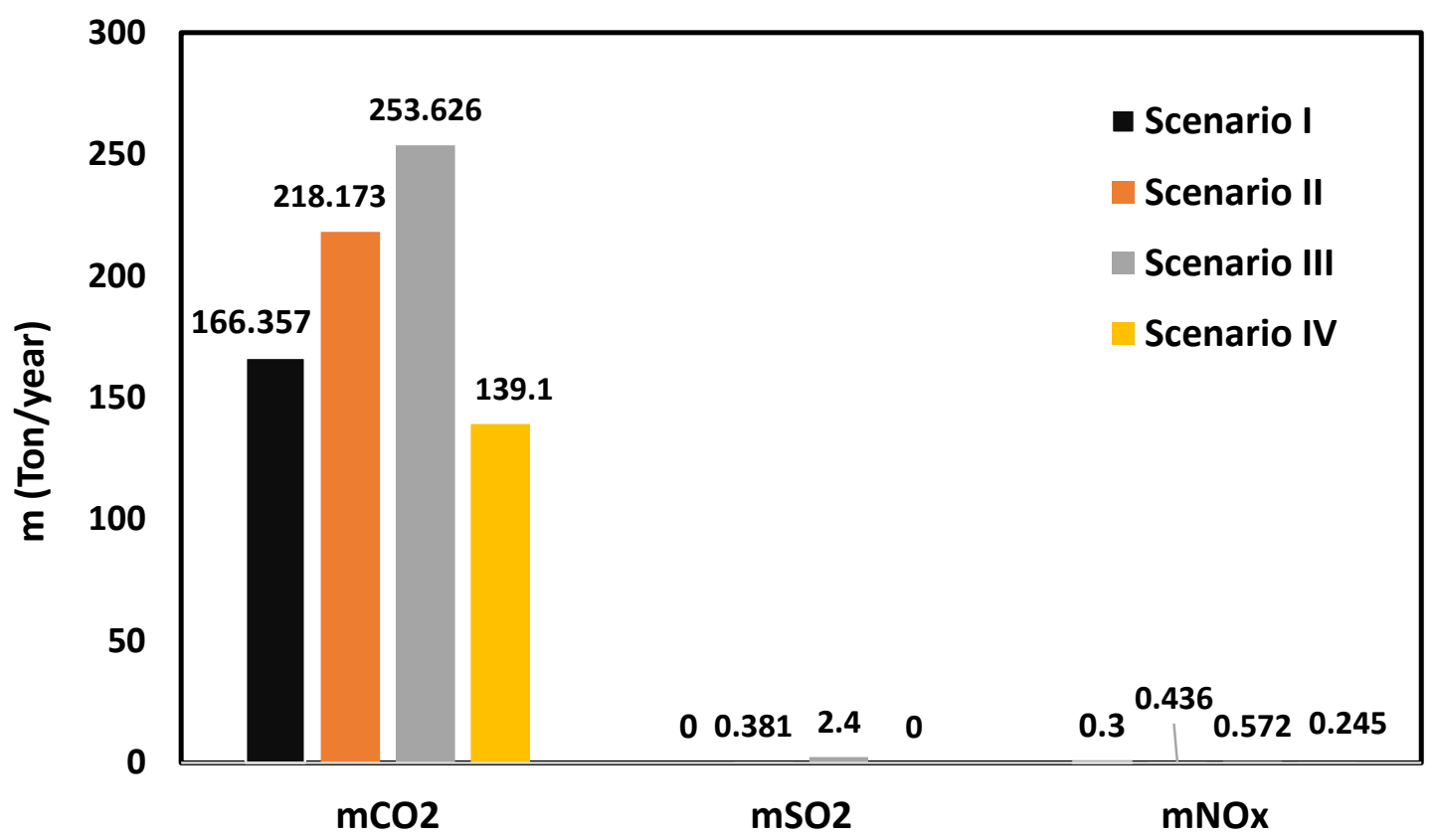

Figure 10. Amount of $\mathrm{CO}_{2}, \mathrm{SO}_{2}, \mathrm{NO}_{x}$ produced in the four scenarios

16) More explanation of result is required.

Ans. Several paragraphs and sentences have been added to the result and discussion section as highlighted in yellow in the revised paper.

17) Overall English need to improve.

Ans. Thank you for your valuable comment. The text has been reviewed to improve the English. 


\section{Research highlights}

- A novel desalination multigeneration system powered by geothermal energy is proposed

- $5 \mathrm{E}$ analyses of multigeneration system producing electricity, cooling, potable water, hydrogen and $\mathrm{NaClO}$

- The cogeneration system combines geothermal energy with reverse osmosis and electrolysis process

- The system energy and exergy efficiencies are equal to $12.25 \%$ and $19.6 \%$

- The payback period time of this system is equal to 2.7 years 


\title{
Energy, Exergy, Economic, Exergoenvironmental, and Environmental analyses of a Multigeneration System to Produce Electricity, Cooling, Potable Water, Hydrogen and Sodium-Hypochlorite
}

\author{
M. A. Ehyaei ${ }^{1 *}$, Simin Baloochzadeh ${ }^{2 *}$, A. Ahmadi ${ }^{3}$, Stéphane Abanades ${ }^{4}$ \\ ${ }^{1}$ Department of Mechanical Engineering, Pardis Branch, Islamic Azad University, Pardis New City \\ 1468995513, Iran; \\ ${ }^{2}$ Faculty of Technology, University of Sunderland, Sunderland, United Kingdom \\ ${ }^{3}$ Iran University of Science and Technology, School of New Technologies, Department of Energy Systems \\ Engineering, Iran \\ ${ }^{4}$ Processes, Materials, and Solar Energy Laboratory, PROMES-CNRS, 7 Rue du Four Solaire, 66120, Font- \\ Romeu, France \\ Corresponding Author: aliehyaei@yahoo.com, mailto:bg17pm@student.sunderland.ac.uk
}

\begin{abstract}
One of the necessities of human beings in this century is the potable water supply. This supply has more environmental benefits if the potable water is supplied by renewable energy resources. In this paper, a combination of combined cooling and power system (Goswami cycle), with the reverse osmosis and sodium hypochlorite plant powered by geothermal energy resources is proposed. The products of this system are electrical and cooling energy, potable water, hydrogen and salt. To investigate all of the system aspects, energy, exergy, economic, exergoenvironmental, and environmental analyses are performed. In environmental analysis, the social costs of air pollution are considered. It means that for the same amount of system electrical power produced by non-renewable energy resource power generation systems, the produced air pollution gases and their costs considering the social cost of air pollution are quantified. In this regard, four scenarios are defined. Results show this multi-generation system produces $1.751 \mathrm{GJ} /$ year electrical energy, $1.04 \mathrm{GJ} /$ year cooling energy, $18106.8 \mathrm{~m}^{3} /$ year potable water, $7.396 \mathrm{Ton} /$ year hydrogen, and 3.838 Ton/year salt throughout a year. The system energy and exergy efficiencies are equal to $12.25 \%$, and $19.6 \%$. The payback period time of this system is equal to 2.7 years.
\end{abstract}

Keywords: Goswami Cycle; Reverse Osmosis; Salt; Exergy; Economic; Exergoenvironmental

\section{Introduction}

Water scarcity is one of the greatest dangers threatening people [1]. This shortage was considered high risk by the World Economic Forum [2]. Around four billion people experience potable water shortage during at least one month of a year and five hundred million experience this all the time year along [3].

Around $0.014 \%$ of global amount of water existing on Earth is potable water. The remaining part is brine water or non-accessible. However, the amount of potable water is sufficient, but regarding unequal distribution, some regions such as the middle east suffer from potable water shortage [4]. 
In addition to the non-equal distribution of potable water, several factors affect the water shortage, such as world population growth, living standard, method of water consumption, agriculture, climate change, and industrial impacts [5].

Thus, supplying potable water is essential for humanity and this can be achieved via desalination. The desalination processes are divided into four main groups: thermal desalination processes [69] (multi-stage flash distillation (MSF), multi-effect distillation (MED), vapor-compression evaporation (VC)); membrane processes [10] (reverse osmosis (RO), electrodialysis (ED), membrane distillation (MD)); freezing [11]; and ion exchange - solvent process [12, 13]. The strengths and weaknesses of desalination methods are depicted in Table 1.

Table 1. Strengths and weaknesses of desalination techniques

\begin{tabular}{|c|c|c|c|c|}
\hline No. & Techniques & Strength & Weakness & Ref \\
\hline \multicolumn{5}{|c|}{ Thermal desalination processes } \\
\hline 1 & MSF & $\begin{array}{ll}- & \text { Relatively simple } \\
\text { - } & \text { Low number moving components } \\
\text { - } & \text { High purification } \\
& \text { quality } \\
\text { - } & \text { The possibility to add more stage } \\
& \text { to performance improvement }\end{array}$ & - $\quad$ Tube clogging & $\begin{array}{l}{[9,11,} \\
14,15]\end{array}$ \\
\hline 2 & MED & $\begin{array}{ll}\text { - } & \text { Less tube corrosion in comparison } \\
\text { with MSF } \\
\text { - } \\
\text { Less sensitive to feed water } \\
\text { quality } \\
\text { - } \quad \text { Lower power consumption in } \\
\text { comparison with MSF } \\
\text { - } \quad \text { Higher efficiency than MSF }\end{array}$ & - $\quad$ Tube clogging & {$[9,15]$} \\
\hline 3 & vC & $\begin{array}{ll}- & \text { Reliability and simplicity } \\
\text { - } & \text { Low operating temperature than } \\
& \text { MED and MSF } \\
\text { - } & \text { Lower tube corrosion } \\
\end{array}$ & $\begin{array}{l}\text { The extra cost for } \\
\text { compressor } \\
\text { The larger size of the heat } \\
\text { exchanger }\end{array}$ & {$[16,17]$} \\
\hline \multicolumn{5}{|c|}{$\begin{array}{l}\text { Membrane processes } \\
\end{array}$} \\
\hline 4 & RO & $\begin{array}{ll}- & \text { Less corrosion } \\
- & \text { Lower prices } \\
- & \text { Usage of turbine recovery } \\
\end{array}$ & $\begin{array}{l}\text { Clogging of membrane } \\
\text { The requirement of a large } \\
\text { quantity of water }\end{array}$ & {$[9,15]$} \\
\hline 5 & ED & $\begin{array}{l}\text { - High recovery } \\
\text { The proportion of energy } \\
\text { requirement to salt removing }\end{array}$ & $\begin{array}{l}\text { - } \begin{array}{l}\text { Non-suitable for water with } \\
\text { particles less than } 0.4 \mathrm{~g} / \mathrm{L} \\
\text { Non-affordable for water } \\
\text { with particles higher than } 30 \\
\mathrm{~g} / \mathrm{L} \\
\text { Low chemical usage for pre- } \\
\text { treatment }\end{array} \\
\end{array}$ & {$[9,18]$} \\
\hline 6 & MD & $\begin{array}{ll}\text { - } & \text { Simplicity } \\
\text { - } & \text { Less operating temperature }\end{array}$ & $\begin{array}{l}\text { - } \quad \text { More space requirement } \\
\text { Same energy usage with } \\
\text { MSF and MED } \\
\text { Needs for feed water with } \\
\text { no organic pollutant }\end{array}$ & {$[9,15]$} \\
\hline \multicolumn{5}{|c|}{ Freezing } \\
\hline
\end{tabular}




\begin{tabular}{|c|c|c|c|c|}
\hline 7 & Freezing & $\begin{array}{l}\text { - } \quad \text { Lower energy requirement } \\
\text { - } \quad \text { Low corrosion } \\
\text { - Very pure potable water }\end{array}$ & $\begin{array}{l}\text { - Hardly moving of ice and } \\
\text { water mixture }\end{array}$ & {$[9,19]$} \\
\hline \multicolumn{5}{|c|}{ Ion exchange - the solvent process } \\
\hline 8 & $\begin{array}{c}\text { Ion exchange - the solvent } \\
\text { process }\end{array}$ & $\begin{array}{ll}- & \text { Low cost } \\
\text { - } & \text { Simplicity } \\
\text { - } & \text { Operation easily }\end{array}$ & $\begin{array}{ll}\text { - } & \text { Long production cycle } \\
\text { - } & \text { Poor quality product } \\
\text { - } & \text { Large PH changes }\end{array}$ & {$[20]$} \\
\hline
\end{tabular}

Based on a survey carried out by Shahzad et al. [21], the potable water demand will increase up to 60 billion $\mathrm{m}^{3}$ by 2050 . This huge amount of water production can be achieved with different types of desalination systems so that the total energy consumption of desalination systems reaches 75.2 TWh per year. Moreover, it was recommended to improve the thermodynamic efficiency of the desalination systems from $10 \%$ to $25 \%$, develop high flux membrane material for RO system, and design high-efficiency hybrid MED/MSF desalination systems.

It is preferable that the thermal and electrical energy needs of the various kinds of desalination system can be met by renewable energy resources due to elimination of pollution during operation time and depletion of non-renewable energy resources such as gas, oil, coal, etc. [22].

Among renewable energy resources, geothermal energy has a high potential for use in industrial and residential applications based on the mass flow rate, temperature, and pressure of geothermal fluid [23]. These applications are divided into many categories such as electrical [24], hydrogen [25], heating and cooling [26], and freshwater productions [27], as well as, cogeneration/multigeneration systems which have two or more products [28].

Hybrid cogeneration of the solar and geothermal based system with ammonia fuel cell was examined for electricity, hydrogen, cooling, and fresh-water production. By this configuration, $42.3 \%$ and $21.3 \%$ energy and exergy efficiency were achieved in this hybrid system. In addition, the effects of different parameters on the system performance were studied by parametric analyses of the total system and associated subsystems [29].

A modified Kalina cycle was integrated with a reverse osmosis system to provide heating, cooling and power, and potable water. In this investigation, energy and exergy analyses were examined to evaluate its performance. The results of this investigation showed that the system can generate $46.77 \mathrm{~kW}$ electricity, $451 \mathrm{~kW}$ heating, $52 \mathrm{~kW}$ cooling, and $0.79 \mathrm{~kg} / \mathrm{s}$ potable water. Also, it was 
concluded that the thermodynamic properties of the steam cycle were dominant because these parameters can affect both the steam cycle and the Kalina cycle [30].

Integration of a photovoltaic system and geothermal source was examined to provide $840 \mathrm{~kW}$ electricity, heating, $5.295 \mathrm{~kg} / \mathrm{s}$ biogas, and $2.773 \mathrm{~kg} / \mathrm{s}$ desalinated water. The mixed fluid cascade cycle was employed for methane liquefaction. Its specific power consumption was reduced to $0.1888 \mathrm{kWh} / \mathrm{kg}$ LNG by application of an absorption refrigeration system. The energy and exergy efficiencies of this integrated system were $73.2 \%$ and $76.8 \%$, respectively [31].

In a study carried out by Behnam et al. [32], exergy and thermo-economic analysis of a novel lowtemperature geothermal heat resource for electricity, hot water, and fresh-water production were examined. Moreover, the sensitivity of decision parameters on the performance of this system was also analyzed. The results of this study showed that by using $100^{\circ} \mathrm{C}$ geothermal water, this system was able to produce $0.662 \mathrm{~kg} / \mathrm{s}$ freshwater, $161.5 \mathrm{~kW}$ power, and $246 \mathrm{~kW}$ heat load.

A multi-effect distillation (MED) desalination plant of $9000 \mathrm{~m}^{3} /$ day with solar (parabolic trough collectors) and geothermal energy resources was examined in Spain. The theoretical results of this study revealed that this amount of fresh water was obtained during $76 \%$ of the annual time with both solar and geothermal resources (at $490 \mathrm{~m}$ depth) and a hot water temperature of $41.8{ }^{\circ} \mathrm{C}$. However, the results of this study revealed by considering a gradient temperature of $8.87{ }^{\circ} \mathrm{C}$ per $100 \mathrm{~m}$ depth, just geothermal energy at depth of $790 \mathrm{~m}$ was enough to obtain working temperature of the desalination plant at $70{ }^{\circ} \mathrm{C}[33]$.

The application of a humidification-dehumidification (HDH) unit in a flash-binary geothermal heat source at $170 \mathrm{~m}$ was examined in a new tri-generation system for power, cooling, and freshwater production. The results of this study showed that the increment of the steam turbine output power, overall cooling load, gain-output-ratio (TGOR), and exergy efficiency of this system was around $77.1 \%, 87 \%, 8.2 \%$, and $46.4 \%$, respectively. The overall exergy destruction of this trigeneration system at the base mode was $946.7 \mathrm{~kW}$. The recovery heat exchanger was recognized as the most destructive component in the base mode with exergy destruction of $308.5 \mathrm{~kW}$ [34].

An integrated system containing parabolic trough solar collectors and wind turbines was examined by Makkah et al. [35]. The benefits of a membrane-thermal desalination system to produce power and freshwater were pointed out. This proposed cogeneration system was employed for providing 
electrical power and fresh water in Iran by three types of desalination system consisting of the Reverse Osmosis (RO), Multi-effect distillation (MED), and Thermal Vapor Compression (TVC). The obtained results from exergy analysis demonstrated that the exergy destruction of the solar collectors and wind turbines contributed by $39.5 \%$ and $22.2 \%$, respectively. The results of multiobjective particle swarm optimization revealed that the exergy efficiency and the cost of freshwater production reach $26.2 \%$ and $3.08 \mathrm{US} \$ / \mathrm{m}^{3}$. The environmental assessments showed that this hybrid system avoids 52164 tons of $\mathrm{CO}_{2}$ emission per year.

A solar organic Rankine cycle (ORC) was employed for power generation and freshwater production by reverse osmosis (RO) desalination units in a power scale less than $500 \mathrm{~kW}$. The performance of the ORC/RO desalination set-up was improved by using a cascade ORC/ORC system. Salinity-gradient solar pond (SGSP) was used instead of the conventional solar collector. These results showed that the ORC/ORC/RO system had the highest performance along with the lowest SUCP (sum unit cost of product) and total exergy destruction. Furthermore, the most economical month $\mathrm{f}$ was June due to the low value of SUCP $(72.42 \$ / \mathrm{kWh})$ since more freshwater was produced in this month [36].

Thermodynamic and thermo-economic performances of a hybrid solar and biomass power plant producing electricity, freshwater, and domestic hot water requirements for a 40 households' community were studied by Mouaky et al [37]. The considered community was located in a semiarid region in Morocco characterized by a good solar potential of $2239 \mathrm{kWh} / \mathrm{m}^{2} / \mathrm{y}$ and by the presence of brackish groundwater. In parabolic solar collectors and boilers, olive waste residues as feedstock were applied as a working fluid to run a $46 \mathrm{~kW}$ ORC and RO unit. The results showed that this proposed system was able to meet the community's requirements with an annual biomass consumption of 235 tons and a solar share of $11.4 \%$. Moreover, this investigation showed that the monthly plant's overall energy efficiency was in a range between 11.3 and $16.3 \%$, while its corresponding exergy efficiency was between 5.3 and $6.0 \%$.

Application of a solar dish collector integrating phase change material storage was used for providing thermal energy of a steam power plant with a capacity of $1063 \mathrm{MW}$. The phase-change material was applied during the night and in the absence of solar thermal sources. In order to prevent heat losses in the condenser, a large part of the dissipated heat was provided to a multi- 
effect desalination system. The desalination system produced $8321 \mathrm{~kg} / \mathrm{s}$ of freshwater by utilizing $2571 \mathrm{MW}$ of waste heat from the steam power plant. The total electrical efficiency of $28.84 \%$ and thermal efficiency of $97.2 \%$ were obtained for this system [38].

A plant consisting of photovoltaic panels, and supplying a RO unit for freshwater production was examined by Calise et al. [39]. The developed system was extremely profitable: the achieved payback period was about 1.3 years, mainly due to the high capital cost of freshwater in the reference scenario. Remarkable water-saving equivalent to $80 \%$ was obtained. For the selected case study, the sensitivity analyses suggested to adopt a solar field area equal to $6,436 \mathrm{~m}^{2}$. The economic consideration revealed low pay-back periods for specific costs of the water higher than $7 € / \mathrm{m}^{3}$.

Design and economic evaluation of solar-powered hybrid multi-effect and reverse osmosis system for seawater desalination were conducted by Filippini et al. [40]. In this study, the possibility of coupling the desalination plant with a photovoltaic (PV) solar farm was investigated to generate electricity at a low cost and in a sustainable way. Data about four locations, namely Isola di Pantelleria (IT), Las Palmas (ES), Abu Dhabi (UAE), and Perth (AUS), have been used to economically test the feasibility of installing the proposed plant, and especially the PV solar farm.

In a research conducted by Sezer et al. [41], the development and performance assessment of new integrated solar, wind, and osmotic power system for multi-generation, based on thermodynamic principles were examined. The results revealed that the overall obtained energy and exergy efficiencies were $73.3 \%$ and $30.6 \%$, respectively. The obtained results showed that this system was able to generate $51.6 \mathrm{MW}$ electrical power, $40.2 \mathrm{MW}$ refrigeration load, $559 \mathrm{~kg} / \mathrm{h}$ hydrogen, and $403.2 \mathrm{~L} / \mathrm{s}$ freshwater.

An integrated solar-driven membrane distillation system for water purification and energy generation was used by Li et al. [42]. It was found that a system with a solar absorbing area of $1.6 \mathrm{~m}^{2}$ coupled with $\sim 0.2 \mathrm{~m}^{2}$ of membranes can produce $\sim 4 \mathrm{~L}$ of drinkable water and $\sim 4.5 \mathrm{kWh}$ of heat energy (at $45^{\circ} \mathrm{C}$ ) per day (with an average daily solar exposure of $4 \mathrm{kWh} / \mathrm{m}^{2}$ ). The economic consideration of this study indicated that this system had a payback time of $\sim 4$ years.

The summary of previous studies is reported in Table 2.

Table 2. Various researches about the multi/cogeneration systems 


\begin{tabular}{|c|c|c|c|c|c|c|c|c|}
\hline No. & Energy resource & Components & Products & Analysis & $\begin{array}{c}\text { Energy } \\
\text { efficiency } \\
(\% 0\end{array}$ & $\begin{array}{c}\text { Exergy } \\
\text { efficiency } \\
(\%)\end{array}$ & $\begin{array}{c}\text { Cost of } \\
\text { products }\end{array}$ & Ref \\
\hline 1 & Solar/Geothermal & RO;PEMFC;ASR;AFC;HSR & $\begin{array}{l}\text { Electricity, } \\
\text { Freshwater, } \\
\text { Hydrogen, and } \\
\text { Cooling }\end{array}$ & Energy/Exergy & 42.3 & 21.3 & - & [29] \\
\hline 2 & Geothermal & $\mathrm{KC}, \mathrm{RO}$ & $\begin{array}{c}\text { Electricity, Heating, } \\
\text { Cooling, and } \\
\text { Freshwater }\end{array}$ & Energy/Exergy & - & 38.1 & - & {$[30]$} \\
\hline 3 & Solar/Geothermal & $\begin{array}{c}\text { Biogas system, MED, ORC; } \\
\text { PV }\end{array}$ & $\begin{array}{l}\text { Bio-liquefied natural } \\
\text { gas; Freshwater, } \\
\text { Electricity }\end{array}$ & Energy/Exergy & 73.2 & 76.8 & - & [31] \\
\hline 4 & Geothermal & ORC; ASR; SSE & $\begin{array}{l}\text { Electricity, Hot and } \\
\text { Fresh water }\end{array}$ & $\begin{array}{l}\text { Energy/Exergy/ } \\
\text { Thermoeconomic }\end{array}$ & 34 & 43 & $\begin{array}{c}\mathrm{LCOE}=0.04 \\
\$ / \mathrm{kWh} \\
\mathrm{LCOW}=29.4 \\
\$ / \mathrm{m}^{3}\end{array}$ & {$[32]$} \\
\hline 5 & Solar/Geothermal & PTC; MED & Freshwater & Feasibility study & - & - & - & [33] \\
\hline 6 & Geothermal & FGPP; HDH & Electriciy/Cooling & Energy/Exergy & 46.4 & $\begin{array}{c}\text { TGOR= } \\
0.9275\end{array}$ & - & [34] \\
\hline 7 & Solar/Geothermal & MED; PTC; ORC & $\begin{array}{l}\text { Electricity; Cooling; } \\
\text { Heating; Freshwater; } \\
\text { Absorption Chiller }\end{array}$ & Exergy/Exergoeconomic & - & 63 & $\begin{array}{c}\text { Electricity } \\
\text { exergoeconomic } \\
\text { cost }=0.1475- \\
0.1722 € / \mathrm{kW} \mathrm{h} \\
\text { Chilled water } \\
\text { exergoeconomic } \\
\text { cost }=0.1863- \\
0.1888 € / \mathrm{kW} \\
\text { hex } \\
\text { Cooling water } \\
\text { exergoeconomic } \\
\text { cost }=0.01612- \\
0.01702 € / \mathrm{kW} \\
\text { hex } \\
\text { Freshwater } \\
\text { exergoeconomic } \\
\text { cost }=0.5695- \\
0.6023 € / \mathrm{kW} \\
\text { hex. }\end{array}$ & {$[34]$} \\
\hline 8 & Solar/Wind & $\begin{array}{c}\text { PTC; Wind turbine; MED; } \\
\text { RO }\end{array}$ & $\begin{array}{l}\text { Electricity/Fresh } \\
\text { water }\end{array}$ & $\begin{array}{l}\text { Energy/ Exergy/ } \\
\text { Exergoeconomic }\end{array}$ & - & 26.2 & $\begin{array}{c}\text { Fresh water } \\
\text { cost }=3.08 \$ / \mathrm{m}^{3}\end{array}$ & {$[35]$} \\
\hline 9 & Solar & Solar Pond; KC; ORC; RO & Electricity/Freshwater & $\begin{array}{l}\text { Thermodynamic/ } \\
\text { Thermoeconomic }\end{array}$ & - & 18 & $\begin{array}{c}\mathrm{SUCP}=101.7 \\
\$ / \mathrm{kWh}\end{array}$ & {$[36]$} \\
\hline 10 & Solar/Biomass & & $\begin{array}{c}\text { Electricity/ } \\
\text { Freshwater/, domestic } \\
\text { hot water (DHW) }\end{array}$ & $\begin{array}{l}\text { Thermodynamic/ } \\
\text { Thermoeconomic }\end{array}$ & $\begin{array}{l}11.3- \\
16.3\end{array}$ & $5.3-6$ & $\begin{array}{l}\text { Electricity cost }= \\
0.231 € / \mathrm{kW} \\
\text { Fresh water } \\
\text { cost }=0.86 € / \mathrm{m}^{3} \\
\text { DHW cost= } \\
0.047 € / \mathrm{kW}\end{array}$ & [37] \\
\hline 11 & Solar & SD; PCM; SC; MED & $\begin{array}{l}\text { Electricity; } \\
\text { Freshwater }\end{array}$ & Energy/ Exergy & 28.8 & 52.2 & - & [38] \\
\hline 12 & Solar & PV; RO & $\begin{array}{l}\text { Electricity; } \\
\text { Freshwater }\end{array}$ & Economic & - & - & $\mathrm{PP}=1.3$ years & [39] \\
\hline 13 & Solar & PV; MED; RO & $\begin{array}{l}\text { Electricity; Fresh } \\
\text { water }\end{array}$ & Economic & - & - & $\begin{array}{c}\text { Electricity cost }= \\
0.1 € / \mathrm{kWh} \\
\text { Fresh water } \\
\text { cost }=0.59 € / \mathrm{m}^{3}\end{array}$ & [40] \\
\hline 14 & Solar/Wind & $\begin{array}{l}\text { Wind Turbine; CPVT; TES; } \\
\text { FC; EL; MSF; VCR; PRO }\end{array}$ & $\begin{array}{c}\text { Electricity; } \\
\text { Freshwater; Cooling; } \\
\text { Hydrogen }\end{array}$ & Energy/ Exergy & 73.3 & 30.6 & - & [41] \\
\hline 15 & Solar & ESC; MD & Freshwater & Economic & - & - & $\mathrm{PP}=4$ years & {$[42]$} \\
\hline \multicolumn{9}{|c|}{ 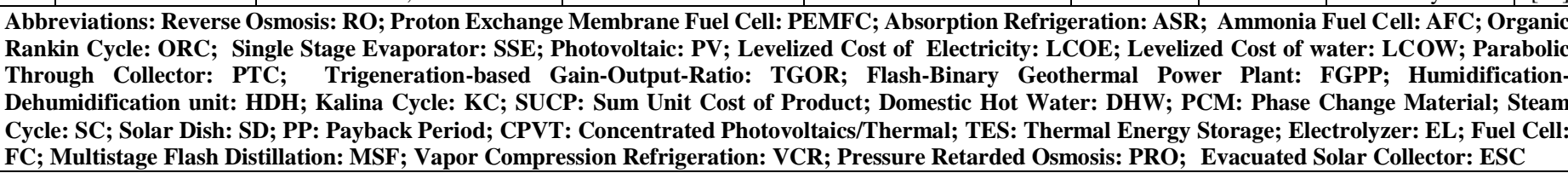 } \\
\hline
\end{tabular}




\subsection{Novelty of the Research}

After careful investigation of the multi/co-generation systems and different products from them, it is clear that the proposed system configuration has not been investigated yet. In this proposed system, three main sub-systems are considered that are power and cooling production (Goswami cycle [43-46]), Reverse Osmosis (RO) with a recovery turbine, hydrogen and sodium hypochlorite $(\mathrm{NaClO})$ production) that are powered by the geothermal energy resource.

Moreover, the products of this system (electrical power, cooling, freshwater, hydrogen, and sodium hypochlorite $(\mathrm{NaClO}))$ are different from the other systems which have been investigated in the literature.

The benefits of the proposed desalination system are varied and the key products are potable water (as main needs for humanity), hydrogen (a key clean fuel for the transportation sector), electrical and cooling energy (as needs for residential, commercial, and industrial applications), and sodiumhypochlorite (a valuable co-product).

Complete analyses covering all aspects of the system including energy, exergy, economic, exergoenvironmental, and environmental have not been considered for any system in the literature.

For the environmental analysis, the relation between environmental detrimental effects and economics is established by considering the social cost of environmental pollution. It is assumed the same amount of electrical power produced by this system is generated by non-renewable power generation systems and the air pollution gases $\left(\mathrm{CO}_{2}, \mathrm{NO}_{\mathrm{x}}, \mathrm{SO}_{2}, \mathrm{CO}\right)$ produced by these assumed systems are calculated. In this regard, four scenarios are defined.

By considering the social cost of these harmful gases, the effects of environmentally harmful gases on economics are evaluated.

The innovations of this paper are as follows:

- Energy, exergy, economic, exergoenvironmmental, and environmental analyses of the multigeneration system to produce electrical, cooling, potable water, hydrogen, and $\mathrm{NaClO}$ simultaneously 
- Establish a relationship between environmental negative effects and economics by considering the social cost of environmental pollution.

\section{Mathematical Modeling}

\subsection{Process Description and Assumptions}

Figure 1 shows the schematic diagram of the proposed system. This system has three sub-systems consisting of cooling and power production system (Goswami cycle), reverse osmosis (RO) with a recovery turbine, and $\mathrm{H}_{2} / \mathrm{NaClO}$ production plant.

The advantage of the Goswami cycle compared to the Kalina cycle is the cooling output, however, with higher temperature source, the Kalina cycle has a better performance [43].

In the power and cooling production system (Goswami cycle), the working fluid is a binary mixture of water and ammonia. This working fluid flows through pump III and it is pressurized (points 1 \& 2). After exchanging the heat with the heated lean ammonia-water mixture in the Recovery Heat Exchanger (RHX), it is transferred to the boiler (points 2, 3, 9 \& 10). In the boiler, the mixture is heated and it is sent to the rectifier/separator (point 4). In the rectifier/separator, the working fluid is divided into rich and lean mixtures (points $5 \& 9$ ). The lean mixture is transferred to the RHX (points $9 \& 10$ ). After reducing the pressure in the throttling valve (point 11), it is transferred to the absorber.

The rich mixture is heated in the superheater and it is converted to the superheated steam (point 6). This superheated steam rotates the turbine and generator to produce electrical power. Then, the low-pressure rich mixture goes through the Refrigeration Heat Exchanger (RHE) to produce cooling (points $7 \& 8$ ). In the absorber, the lean and rich mixtures are mixed (points $8,11 \& 1$ ).

The energy needs of the boiler and superheater are met to be supplied by the geothermal working fluid. After extraction of the geothermal working fluid from the production well (point 12), it is pressurized in the pump I (point 13) and then flows through the superheater and boiler to warm up the ammonia-water mixture (points $14 \& 15$ ).

In the RO, the seawater goes through high-pressure pumps (points 16, 17, 18, $19 \& 20$ ), and then it is transferred to the membranes I \& II to separate the salt. The potable water (points $21,23 \&$ 25 ) is stored in the water storage tank (point 26). The high-pressure drain rotates the recovery 
turbine (points 22, $24 \& 27$ ) to produce the electrical power (point 28). The part of the low-pressure drain water (point 29) is transferred to the $\mathrm{NaClO}$ plant to produce hydrogen and sodium hypochlorite $(\mathrm{NaClO})$ (points $30 \& 31)$.

In this system, the electrical power is produced in the turbine (Goswami cycle) and the recovery turbine. The part of this produced electricity is consumed internally by the pumps I to IV and $\mathrm{NaClO}$ plant. The remaining part can be used by consumers. The system Grassman diagram is shown in Figure 2. 


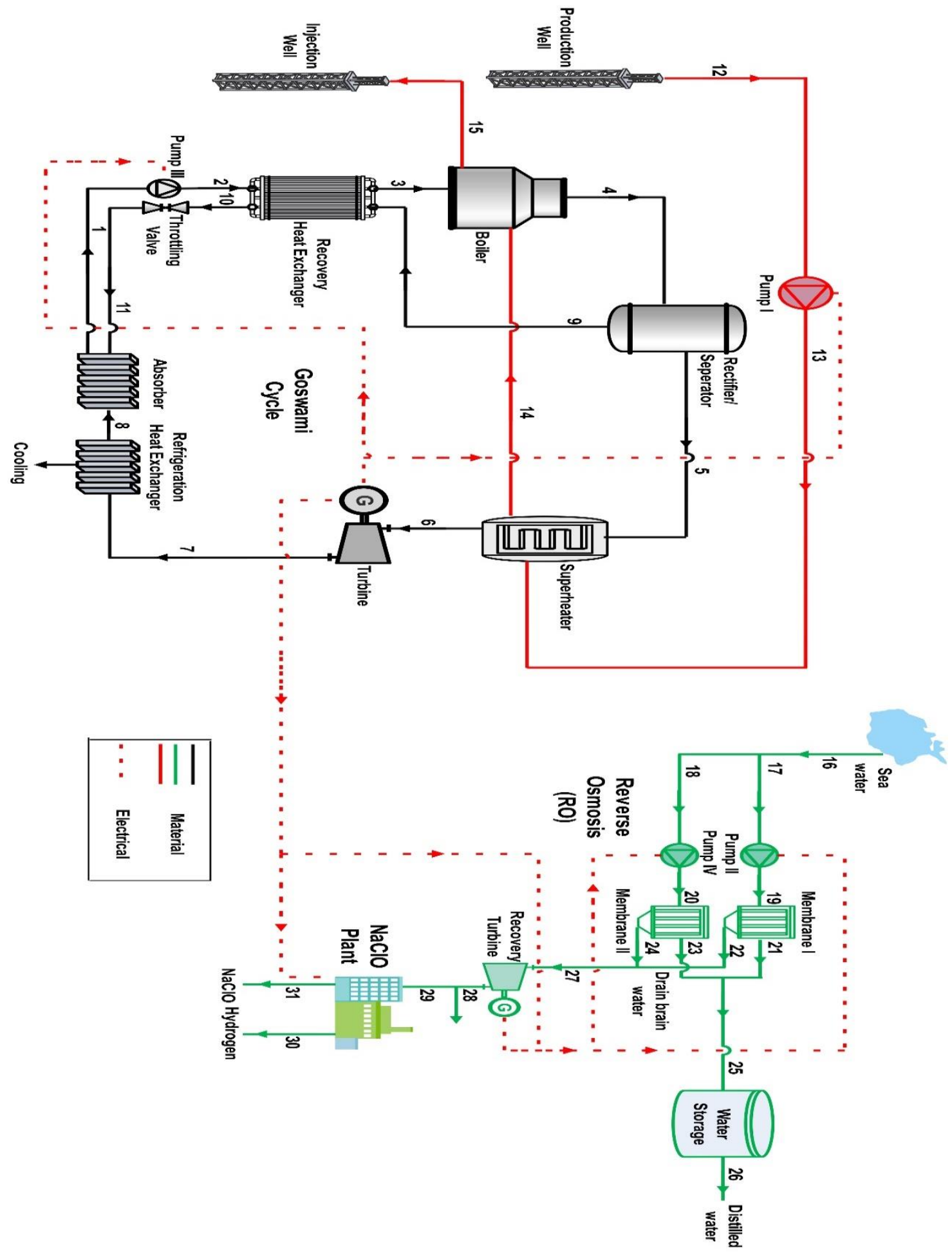

Figure 1. Proposed system schematic diagram 


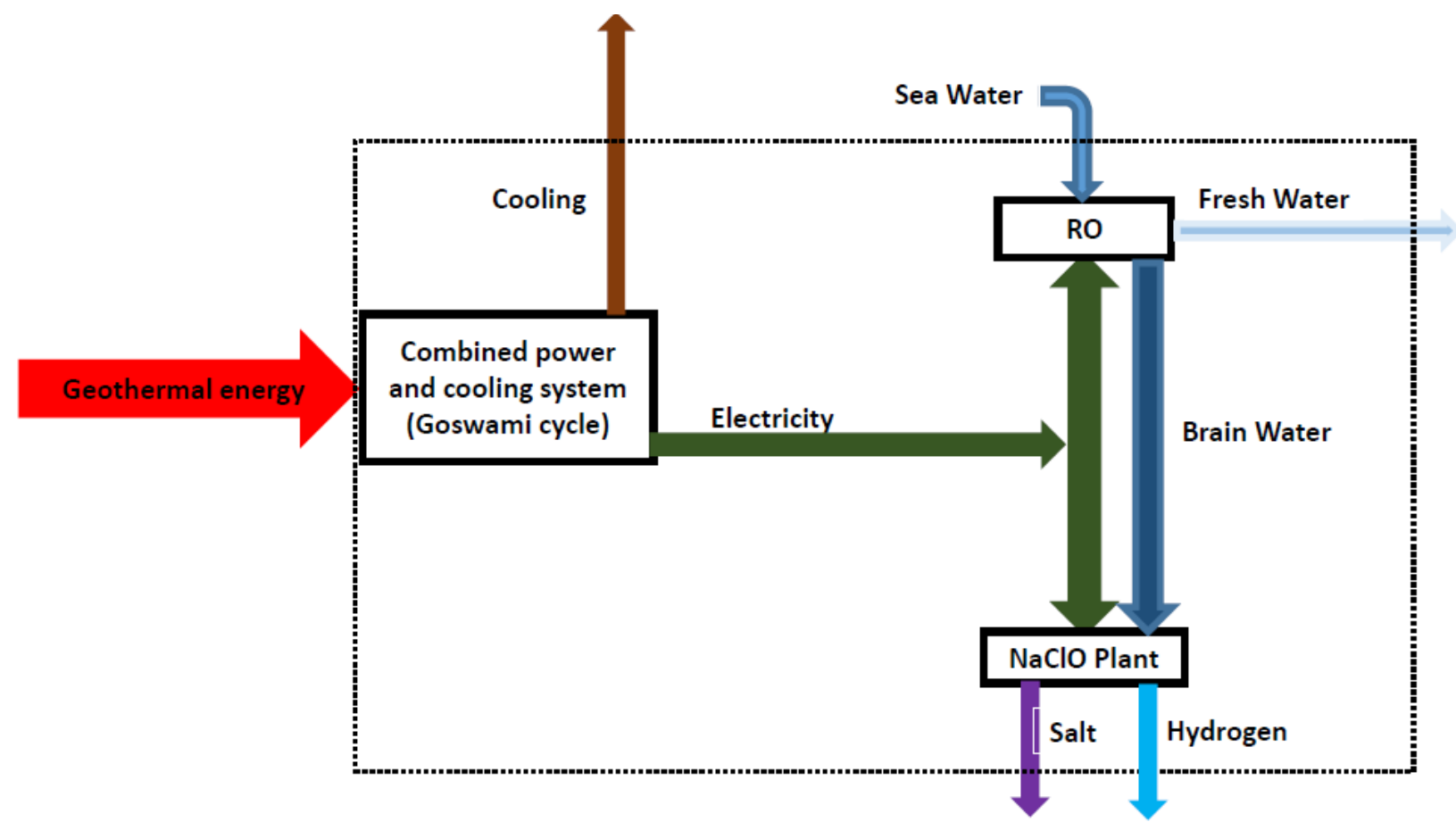

Figure 2. Grassman diagram of the system

The following assumptions are considered [23, 43, 47-54]:

1- Steady-state operation.

2- The pump and turbine polytrophic efficiencies are equal to $85 \%$, respectively.

3- The heat exchanger effectiveness factor is $85 \%$.

4- The geothermal working fluid pressure, temperature, and mass flow rate are equal to 2 bar, $120^{\circ} \mathrm{C}$, and $15 \mathrm{~kg} / \mathrm{s}$, respectively. The location of geothermal wells is in the Bandar Abbas city located in the southern of Iran. The type of geothermal resource is hydrothermal.

5- The dead state pressure and temperature are $15^{\circ} \mathrm{C}$ and $1 \mathrm{bar}$, respectively.

6- The potential and kinetic energy are neglected.

7- The pressure loss is neglected.

8- The process in the throttling valve is adiabatic.

9- The recovery ratio in the $\mathrm{RO}$ system is 0.3 .

10- Heat exchangers are shell and tube type.

11- In the environmental analysis, air pollution is considered as environmental pollutions.

12- The polarization effects are ignored in this study. 


\subsection{Mass, Concentration, and Energy Balance}

Generally, the mass and energy conservation equations are written as follows [55]:

$$
\begin{aligned}
& \sum_{\text {in }} \dot{m}=\sum_{\text {out }} \dot{m} \\
& \dot{Q}-\dot{W}=\sum_{P} \dot{m}\left(h_{f}+\left(h-h_{0}\right)\right)-\sum_{R} \dot{m}\left(h_{f}+\left(h-h_{0}\right)\right)
\end{aligned}
$$

In which $\dot{\mathrm{W}}$ and $\dot{\mathrm{Q}}$ are the work and heat transfer rate, $\mathrm{h}$ and $\dot{\mathrm{m}}$ are enthalpy and mass flow rate, respectively. Subscripts $\mathrm{P}, \mathrm{R}$, f, and 0 mean product, reactant, formation, and dead state, respectively.

The mass, concentration, and energy balance equations for the combined power and cooling system (Goswami cycle) and geothermal loop are shown in Table 3 [56-58].

\begin{tabular}{|c|c|c|c|c|}
\hline No. & Components & Mass balance & Energy equation & $\mathrm{X}$ \\
\hline \multicolumn{5}{|c|}{ Combined power and cooling system (Goswami cycle) } \\
\hline 1 & Pump III (P) & $\dot{m}_{1}=\dot{m}_{2}$ & $\dot{w}_{p I I I}=\dot{m}_{1}\left(h_{2}-h_{1}\right)$ & $X_{1}=X_{2}$ \\
\hline 2 & Throttling value & $\dot{m}_{10}=\dot{m}_{11}$ & $h_{10}=h_{11}$ & $X_{10}=X_{11}$ \\
\hline 3 & $\begin{array}{l}\text { Recovery heat } \\
\text { exchanger }\end{array}$ & $\begin{array}{l}\dot{m}_{3}=\dot{m}_{2} \\
\dot{m}_{10}=\dot{m}_{9}\end{array}$ & $\begin{aligned} \dot{m}_{20}\left(h_{9}-h_{10}\right) \eta_{R H X} & \\
& =\dot{m}_{2}\left(h_{3}-h_{2}\right)\end{aligned}$ & $\begin{array}{l}X_{3}=X_{2} \\
X_{10}=X_{9}\end{array}$ \\
\hline 4 & Boiler & $\begin{array}{l}\dot{m}_{3}=\dot{m}_{4} \\
\dot{m}_{14}=\dot{m}_{15}\end{array}$ & $\begin{aligned} \dot{m}_{14}\left(h_{14}-h_{15}\right) \eta_{\text {Boiler }} & \\
& =\dot{m}_{3}\left(h_{4}-h_{3}\right)\end{aligned}$ & $X_{3}=X_{4}$ \\
\hline 5 & $\begin{array}{l}\text { Rectifier/ separator } \\
\text { (RS) }\end{array}$ & $\dot{m}_{4}=\dot{m}_{5}+\dot{m}_{9}$ & $\dot{m}_{4} h_{4}=\dot{m}_{5} h_{5}+\dot{m}_{9} h_{9}$ & $\dot{m}_{4} X_{4}=\dot{m}_{9} X_{9}+\dot{m}_{5} X_{5}$ \\
\hline 6 & Superheater $(\mathrm{SH})$ & $\begin{array}{l}\dot{m}_{5}=\dot{m}_{6} \\
\dot{m}_{13}=\dot{m}_{14}\end{array}$ & $\dot{m}_{13}\left(h_{13}-h_{14}\right) \eta_{S H}=\dot{m}_{5}\left(h_{6}-h_{5}\right)$ & $X_{5}=X_{6}$ \\
\hline 7 & Turbine $(\mathrm{T})$ & $\dot{m}_{6}=\dot{m}_{7}$ & $\dot{w}_{T}=\dot{m}_{6}\left(h_{6}-h_{7}\right)$ & $X_{6}=X_{7}$ \\
\hline 8 & $\begin{array}{l}\text { Refrigeration heat } \\
\text { exchanger (RHE) }\end{array}$ & $\dot{m}_{7}=\dot{m}_{8}$ & $\dot{Q}_{R H E}=\dot{m}_{7}\left(h_{7}-h_{8}\right)$ & $X_{7}=X_{8}$ \\
\hline 9 & Absorber (Abs) & $\dot{m}_{8}+\dot{m}_{11}=\dot{m}_{1}$ & $\dot{Q}_{A b s}=\dot{m}_{8} h_{8}+\dot{m}_{11} h_{11}-\dot{m}_{1} h_{1}$ & $\dot{m}_{8} X_{8}+\dot{m}_{11} X_{11}=\dot{m}_{1} X_{1}$ \\
\hline \multicolumn{5}{|c|}{ Geothermal loop } \\
\hline 10 & Pump I (P) & $\dot{m}_{12}=\dot{m}_{13}$ & $\dot{w}_{p I}=\dot{m}_{12}\left(h_{12}-h_{13}\right)$ & - \\
\hline
\end{tabular}

Table 3. Mass, concentration, and energy balance equations for the Goswami cycle

In Table $3, \dot{m}, h, X$, and $\eta$ mean mass flow rate, enthalpy, ammonia mass ratio, and polythrophic efficiency for rotary equipment (pump and turbine), as well as, effectiveness factor for boiler, superheater, and heat exchangers. 
In RO sub-system, the mass and concentration balance equations are as follows $[49,59,60]$ :

$$
\begin{aligned}
& \dot{m}_{S W}=\dot{m}_{B W}+\dot{m}_{P W} \\
& \dot{m}_{S W} x_{S W}=\dot{m}_{P W} x_{P W}+\dot{m}_{B W} x_{B W}
\end{aligned}
$$

where $x$ is the salt concentration. Subscripts $S W, P W$, and $B W$ denote seawater, potable water, and brain water, respectively.

The relation between sea and portable water is as follows [49, 59]:

$$
\dot{m}_{P W}=R R \dot{m}_{S W}
$$

where RR is the recovery ratio.

Osmosis pressure for the three main streams are calculated by $[49,59]$ :

$$
\begin{aligned}
& \pi_{S W}=R T \times x_{S W} \\
& \pi_{P W}=R T \times x_{P W} \\
& \pi_{B W}=R T \times x_{B W}
\end{aligned}
$$

$\mathrm{R}$ is the universal gas constant.

The net pressure in the membrane is calculated by [49, 59]:

$$
\Delta \pi=\left(\frac{\pi_{S W}+\pi_{B W}}{2}\right)-\pi_{P W}
$$

The water permeability coefficient is calculated by $[49,59]$ :

$$
K_{W}=\frac{6.84 \times 10^{-8}\left(18.68-0.177 x_{B W}\right)}{T_{S W}}
$$

The net pressure of the RO pump is calculated by [49, 59]: 
$\Delta P=\frac{\dot{m}_{P W}}{K_{W} A_{m}}+\Delta \pi$

$A_{m}$ is the membrane area.

The power needs of the RO pump is calculated as $[49,59]$ :

$$
\dot{W}_{P, R O}=\frac{\Delta P \dot{m}_{S W}}{\rho_{S W} \eta_{P, R O}}
$$

where $\rho$ is the density.

The mass, concentration, and energy balance equations for the RO sub-system are presented in Table 4.

Table 4. Mass, concentration, and energy balance equations for the RO sub-system

\begin{tabular}{|l|l|c|c|c|}
\hline No. & Components & Mass balance & Energy equation & x \\
\hline 1 & Pump II & $\dot{m}_{17}=\dot{m}_{19}$ & $\dot{W}_{P I I}=\dot{m}_{17}\left(h_{19}-h_{17}\right)$ & $x_{17}=x_{19}$ \\
\hline 2 & Pump IV & $\dot{m}_{18}=\dot{m}_{20}$ & $\dot{W}_{P I V}=\dot{m}_{18}\left(h_{20}-h_{18}\right)$ & $x_{18}=x_{20}$ \\
\hline 3 & Membrane I & $\dot{m}_{19}=\dot{m}_{21}+\dot{m}_{22}$ & $\dot{m}_{19} h_{19}=\dot{m}_{21} h_{21}+\dot{m}_{22} h_{22}$ & $\dot{m}_{19} x_{19}=\dot{m}_{21} x_{21}+\dot{m}_{22} x_{22}$ \\
\hline 4 & Membrane II & $\dot{m}_{20}=\dot{m}_{23}+\dot{m}_{24}$ & $\dot{m}_{20} h_{20}=\dot{m}_{23} h_{23}+\dot{m}_{24} h_{24}$ & $\dot{m}_{20} x_{20}=\dot{m}_{23} x_{23}+\dot{m}_{24} x_{24}$ \\
\hline 5 & Recovery turbine & $\dot{m}_{27}=\dot{m}_{28}$ & $\dot{W}_{\text {Recovery turbine }=} \dot{m}_{27}\left(h_{27}-h_{28}\right)$ & $x_{27}=x_{28}$ \\
\hline
\end{tabular}

In which $\mathrm{x}$ means the concentration of salt.

In the $\mathrm{NaClO}$ plant, the following reaction happens:

$$
\mathrm{NaCl}+\mathrm{H}_{2} \mathrm{O} \rightarrow \mathrm{NaClO}+\mathrm{H}_{2}
$$

For the $\mathrm{NaClO}$ plant, the following relations between temperature and concentration ratio are considered [49, 59]: 


$$
\begin{aligned}
& T_{\text {NaClo }}=T_{B W}+14 \\
& x_{\text {NaClO }}=\frac{1}{6} x_{B W}
\end{aligned}
$$

The power need of the $\mathrm{NaClO}$ plant is calculated by $[49,59]$ :

$$
\dot{W}_{\text {NaClO }}=\frac{10^{-5}\left(5.9 \times 3600 \times \dot{\mathrm{m}}_{\text {NaClO }} \times x_{N a C l O}\right)}{1.05}
$$

Table 5 shows the mass, concentration, and energy balance equations for the $\mathrm{NaClO}$ plant.

Table 5. Mass, concentration, and energy balance equations for the $\mathrm{NaClO}$ plant.

\begin{tabular}{|l|c|}
\hline Mass balance & $\dot{m}_{29}=\dot{m}_{30}+\dot{m}_{31}$ \\
\hline Concentration balance & $\dot{m}_{29} x_{29}=\dot{m}_{30} x_{30}+\dot{m}_{31} x_{31}$ \\
\hline Energy balance & $\dot{m}_{29} h_{29}+\dot{W}_{N a C l O}=\dot{m}_{31} h_{31}+\dot{m}_{30} h_{30}$ \\
\hline
\end{tabular}

The electrical power production equations for the Goswami, Goswami/RO, and system plants are shown below:

$$
\begin{aligned}
& \dot{W}_{\text {net,Goswami }}=\dot{W}_{T}-\dot{W}_{P, I}-\dot{W}_{P, I I I} \\
& \dot{W}_{\text {net,Goswami } / R O}=\dot{W}_{T}+\dot{W}_{\text {recovery turbine }}-\sum_{i=1}^{4} \dot{W}_{P, i} \\
& \dot{W}_{\text {net,sys }}=\dot{W}_{T}+\dot{W}_{\text {recovery turbine }}-\sum_{i=1}^{4} \dot{W}_{P, i}-\dot{W}_{N a C l o}
\end{aligned}
$$

The energy efficiency equations for the Goswami, Goswami/RO, and system plants are defined as:

$$
\begin{aligned}
& \eta_{\text {en,Gowsami }}=\frac{\dot{W}_{\text {net,Goswami }}}{\dot{m}_{12}\left(h_{12}-h_{15}\right)} \\
& \eta_{\text {en,Gowsami/Ro }}=\frac{\dot{W}_{\text {net }, \text { Goswami/RO }+\dot{m}_{25} h_{25}}}{\dot{m}_{12}\left(h_{12}-h_{15}\right)}
\end{aligned}
$$




$$
\eta_{\text {en }, \text { system }}=\frac{\dot{m}_{31} h_{31}+\dot{m}_{30} h_{30}+\dot{m}_{25} h_{25}+\dot{W}_{\text {net }, \text { Goswami } / R O / N a C l O}}{\dot{m}_{12}\left(h_{12}-h_{15}\right)}
$$

\subsection{Exergy Analysis}

Exergy analysis is carried out by including four parts which are physical, chemical, kinetic, and potential. Specific exergy equation is written below [61, 62]:

$$
e=\sum x_{i} e x_{c h i}+\frac{V^{2}}{2}+g z+\left(h-h_{0}\right)-T_{0}\left(s-s_{0}\right)+T_{0} \sum x_{i} R_{i} \ln y_{i}
$$

$\mathrm{e}$ and $\mathrm{x}$ are specific exergies and mass fraction. $\mathrm{V}, \mathrm{g}$, and $\mathrm{z}$ are defined as velocity, gravitational acceleration, and height. h, T, s, y are specific enthalpy, entropy, temperature, and mole fraction. Abbreviations ch, i, and 0 are defined as chemical, species, and dead state condition.

Tables 6, 7, and 8 show the exergy destruction rate and exergy efficiency for each component of the combined power and cooling system and geothermal loop (Goswami cycle), $\mathrm{RO}$, and $\mathrm{NaClO}$ plant, respectively.

Table 6. Exergy efficiency and exergy destruction rate for each component of the combined

\begin{tabular}{|c|c|c|c|}
\hline No. & Components & Exergy efficiency & Exergy destruction rate $(\mathrm{kW})$ \\
\hline \multicolumn{4}{|c|}{ Combined power and cooling system (Goswami cycle) } \\
\hline 1 & Pump III (P) & $\frac{\dot{W}_{P I I I}}{\dot{m}_{1}\left(e_{2}-e_{1}\right)}$ & $\dot{m}_{1} e_{1}-\dot{m}_{2} e_{2}+\dot{W}_{P I I I}$ \\
\hline 2 & Throttling value & $\frac{\dot{m}_{11} e_{11}}{\dot{m}_{10} e_{10}}$ & $\dot{m}_{11} e_{11}-\dot{m}_{10} e_{10}$ \\
\hline 3 & $\begin{array}{l}\text { Recovery heat } \\
\text { exchanger }\end{array}$ & $\frac{\dot{m}_{2}\left(e_{3}-e_{2}\right)}{\dot{m}_{20}\left(e_{9}-e_{10}\right)}$ & $\dot{m}_{2} e_{2}+\dot{m}_{9} e_{9}-\dot{m}_{3} e_{3}-\dot{m}_{10} e_{10}$ \\
\hline 4 & Boiler & $\frac{\dot{m}_{3}\left(e_{4}-e_{3}\right)}{\dot{m}_{11}\left(e_{14}-e_{15}\right)}$ & $\begin{aligned} \dot{m}_{3} e_{3}+\dot{m}_{14} e_{14}- & \dot{m}_{15} e_{15} \\
& -\dot{m}_{4} e_{4}\end{aligned}$ \\
\hline 5 & $\begin{array}{l}\text { Rectifier/ separator } \\
\text { (RS) }\end{array}$ & $\frac{\dot{m}_{5} e_{5}+\dot{m}_{9} e_{9}}{\dot{m}_{4} e_{4}}$ & $\dot{m}_{4} e_{4}-\dot{m}_{5} e_{5}-\dot{m}_{9} e_{9}$ \\
\hline 6 & Superheater $(\mathrm{SH})$ & $\frac{\dot{m}_{5}\left(e_{6}-e_{5}\right)}{\dot{m}_{6}\left(e_{13}-e_{14}\right)}$ & $\begin{aligned} \dot{m}_{13} e_{13}+\dot{m}_{5} e_{5}- & \dot{m}_{6} e_{6} \\
& -\dot{m}_{14} e_{14}\end{aligned}$ \\
\hline 7 & Turbine $(\mathrm{T})$ & $\dot{m}_{6}\left(e_{6}-e_{7}\right)-\dot{W}_{T}$ & $\frac{\dot{W}_{T}}{\dot{m}_{6}\left(e_{6}-e_{7}\right)}$ \\
\hline 8 & $\begin{array}{l}\text { Refrigeration heat } \\
\text { exchanger (RHE) }\end{array}$ & $\dot{m}_{7}\left(e_{7}-e_{8}\right)-\dot{Q}_{R H E}\left(1-\frac{T_{8}}{T_{0}}\right)$ & $\frac{\dot{Q}_{R H E}\left(1-\frac{T_{8}}{T_{0}}\right)}{\dot{m}_{7}\left(e_{7}-e_{8}\right)}$ \\
\hline
\end{tabular}
power and cooling system and geothermal loop (Goswami cycle) 


\begin{tabular}{|c|l|c|c|}
\hline 9 & Absorber (Abs) & $\dot{m}_{8} e_{8}+\dot{m}_{11} e_{11}-\dot{m}_{1} e_{1}-\dot{Q}_{a b s}$ & $\frac{\dot{\boldsymbol{m}}_{\mathbf{1}} \boldsymbol{e}_{\mathbf{1}}}{\dot{\boldsymbol{m}}_{\mathbf{8}} \boldsymbol{e}_{\mathbf{8}}+\dot{\boldsymbol{m}}_{\mathbf{1 1}} \boldsymbol{e}_{\mathbf{1 1}}-\dot{\boldsymbol{Q}}_{\boldsymbol{a b s}}}$ \\
\hline \multicolumn{3}{|c|}{ Geothermal loop } \\
\hline 10 & Pump I (P) & $\frac{\dot{W}_{P I}}{\dot{m}_{1}\left(e_{13}-e_{12}\right)}$ & $\dot{\boldsymbol{m}}_{\mathbf{1 2}} \boldsymbol{e}_{\mathbf{1 2}}-\dot{\boldsymbol{m}}_{\mathbf{1 3}} \boldsymbol{e}_{\mathbf{1 3}}+\dot{W}_{\boldsymbol{P I I I}}$ \\
\hline
\end{tabular}

Table 7. Exergy destruction rate and exergy efficiency for each component of the RO system

\begin{tabular}{|l|l|c|c|}
\hline No. & Components & Exergy efficiency & Exergy destruction rate (kW) \\
\hline 1 & Pump II & $\frac{\dot{W}_{P I I}}{\dot{m}_{17}\left(e_{19}-e_{17}\right)}$ & $\dot{m}_{17}\left(e_{17}-e_{19}\right)+\dot{W}_{P I I}$ \\
\hline 2 & Pump IV & $\frac{\dot{W}_{P I V}}{\dot{m}_{18}\left(e_{20}-e_{18}\right)}$ & $\dot{m}_{18}\left(e_{18}-e_{20}\right)+\dot{W}_{P I V}$ \\
\hline 3 & Membrane I & $\frac{\dot{m}_{21} e_{21}}{\dot{m}_{19} e_{19}}$ & $\dot{m}_{19} e_{19}-\dot{m}_{21} e_{21}-\dot{m}_{22} e_{22}$ \\
\hline 4 & Membrane II & $\frac{\dot{m}_{23} e_{23}}{\dot{m}_{20} e_{20}}$ & $\dot{m}_{20} e_{20}-\dot{m}_{23} e_{23}-\dot{m}_{24} e_{24}$ \\
\hline 5 & Recovery turbine & $\frac{\dot{W}_{\text {recovery turbine }}}{\dot{m}_{17}\left(e_{27}-e_{28}\right)}$ & $\dot{m}_{27} e_{27}-\dot{m}_{28} e_{28}-\dot{W}_{\text {recovery turbine }}$ \\
\hline
\end{tabular}

Table 8. Exergy efficiency and exergy destruction rate for each component of the $\mathrm{NaClO}$ plant

\begin{tabular}{|l|c|}
\hline Exergy efficiency & $\frac{\dot{m}_{31} e_{31}}{\dot{W}_{N a C l O}}$ \\
\hline Exergy destruction rate & $\dot{m}_{29} e_{29}+\dot{W}_{N a C l O}-\dot{m}_{30} e_{30}-\dot{m}_{31} e_{31}$ \\
\hline
\end{tabular}

The exergy efficiency equations for the Goswami, Goswami/RO, and system are presented below:

$$
\begin{aligned}
& \eta_{\text {ex,Gowsami }}=\frac{\dot{W}_{\text {net }, \text { Goswami }}}{\dot{m}_{12}\left(e_{12}-e_{15}\right)} \\
& \eta_{\text {ex,Gowsami } / R O}=\frac{\dot{W}_{\text {net }, \text { Goswami } / R O+\dot{m}_{25} e_{25}}}{\dot{m}_{12}\left(e_{12}-e_{15}\right)} \\
& \eta_{\text {ex,sys }}=\frac{\dot{W}_{\text {net }, \text { sys }}+\dot{m}_{31} e_{31}+\dot{m}_{30} e_{30}+\dot{m}_{25} e_{25}}{\dot{m}_{12}\left(e_{12}-e_{15}\right)}
\end{aligned}
$$

\subsection{Economic Evaluation}

The cogeneration annual income $\mathrm{CF}$ is calculated as follows [63, 64]: 


$$
C F=Y_{\text {power }} k_{\text {power }}+Y_{\text {cooling }} k_{\text {cooling }}+Y_{P W} k_{P W}+Y_{\text {NaCl }} k_{\mathrm{NaCl}}+Y_{H 2} k_{H 2}
$$

where $\mathrm{k}$ and $\mathrm{Y}$ are products specific cost and annual capacity of system productions. The production costs are shown in Table 9.

Table 9. Specific cost of fuel and products

\begin{tabular}{|c|c|c|c|}
\hline Specific cost of products & Unit & Value & Ref. \\
\hline $\mathbf{k}_{\text {power }}$ & $\mathrm{US} \$ / \mathrm{kWh}$ & 0.22 & [65] \\
\hline kPW & $\mathrm{US} \$ / \mathrm{kg}$ & 0.0004 & [66] \\
\hline $\mathbf{k}_{\text {cooling }}$ & US $\$ / \mathrm{kWh}$ & 0.07 & [67] \\
\hline $\mathbf{k N a C l}_{\mathrm{Na}}$ & $\mathrm{US} \$ / \mathrm{kg}$ & 10.5 & [68] \\
\hline $\mathrm{k}_{\mathrm{H} 2}$ & US\$ $/ \mathrm{kg}$ & 13.99 & [69] \\
\hline
\end{tabular}

The system investment cost equation is given below [63, 64]:

$$
C_{0}=K_{\text {Goswami }}+K_{\text {Geothermal loop }}+K_{R O}+K_{\text {NaClo }}
$$

$\mathrm{K}$ is the investment and installation cost of each subsystem shown in Table 10. For the operation and maintenance cost, $3 \%$ of the initial cost is considered [63, 64].

Table 10. $\mathrm{K}$ values for different components

\begin{tabular}{|c|c|c|c|}
\hline No. & Components & Cost function & Ref \\
\hline \multicolumn{4}{|c|}{ Combined power and cooling system (Goswami cycle) } \\
\hline 1 & Pump & $1120 \dot{W}^{0.8}$ & {$[70-73]$} \\
\hline
\end{tabular}




\begin{tabular}{|c|c|c|c|}
\hline 2 & Throttling value & Neglected & {$[50,74]$} \\
\hline 3 & Heat exchanger & $588 A^{0.8}$ & [70-72] \\
\hline 4 & Boiler & $588 A^{0.8}$ & {$[70-72]$} \\
\hline 5 & Superheater (SH) & $588 A^{0.8}$ & {$[70-72]$} \\
\hline 6 & Turbine & $4405 \dot{W}^{0.7}$ & [70-73] \\
\hline 7 & Rectifier/Separator & 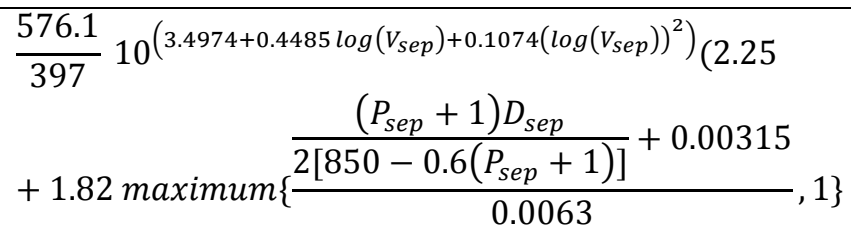 & {$[75]$} \\
\hline 8 & Absorber (Abs) & $0.322\left(30000+0.75 A^{0.8}\right)$ & [66] \\
\hline \multicolumn{4}{|c|}{ Geothermal loop } \\
\hline 9 & Pump & $3540 \dot{W}^{0.71}$ & {$[76,77]$} \\
\hline 10 & Drilling well & $16.5 z^{1.607}$ & [78] \\
\hline \multicolumn{4}{|c|}{$\mathbf{R O}$} \\
\hline 11 & Pump & $996(86400 \dot{Q})^{0.8}$ & [79] \\
\hline 12 & Membrane & 50 & [67] \\
\hline 13 & Tank & $1.14\left(158,62 V_{\text {Tank }}+18321\right.$ & {$[80]$} \\
\hline 14 & Recovery turbine & $52\left(86400 \dot{Q} \Delta P^{0.8}\right)$ & {$[79]$} \\
\hline \multicolumn{4}{|c|}{ NaClO Plant } \\
\hline 15 & $\begin{array}{l}\text { NaClO Plant } \\
\text { (Model HD:6000) }\end{array}$ & 45000 & {$[81]$} \\
\hline
\end{tabular}

In Table 10, z, D, and V mean depth of geothermal well, diameter, and volume, respectively. Subscript sep denotes separator.

For estimating the surface area of the heat exchanger, the logarithmic method is applied. In this regard, the following equation is considered [82]:

$$
\dot{Q}=U A F_{t} \Delta T_{I n}
$$

where $\dot{Q}, U, A, F_{t}$, and $\Delta T_{I n}$ are the heat transfer rate, overall heat transfer coefficient, surface area, correction factor, and logarithmic mean temperature difference. The overall heat transfer coefficient for various components is shown in Table 10 [50]. The method for estimating the volume of the separator is explained in Ref. [83]. 
Table 11. U values for various components

\begin{tabular}{|c|c|c|}
\hline No. & Components & $\boldsymbol{U}\left(\boldsymbol{W} / \boldsymbol{m}^{2} \boldsymbol{K}\right)$ \\
\hline 1 & Separator & 300 \\
\hline 2 & Boiler & 500 \\
\hline 3 & Heat exchanger & 700 \\
\hline 4 & Absorber & 800 \\
\hline
\end{tabular}

Since the cost function is based on various years, the effect of inflation can be represented by the following equation [84]:

$$
C_{n}=C_{0}(1+i)^{n}
$$

where $\mathrm{n}$ is the number of years, and $\mathrm{i}$ is the inflation rate which is equal to $3.11 \%$ [85].

The simple payback period (SPP) index is calculated by $[63,64]$ :

$$
S P P=\frac{C_{n}}{C F}
$$

The payback period (PP) index can be expressed as $[63,64]$ :

$$
P P=\frac{\ln \left(\frac{C_{F}}{C F-r \cdot C_{n}}\right)}{\ln (1+r)}
$$

where $\mathrm{r}$ represents the discount factor $(3 \%)$.

The Net Present Value (NPV) is obtained as [63, 64]:

$$
N P V=C F \frac{(1+r)^{N}-1}{r(1+r)^{N}}-C_{n}
$$

$\mathrm{N}$ is the project lifetime that is considered 25 years.

The Internal Rate of Return (IRR) is given by $[63,64,86]$ :

$$
I R R=\frac{C F}{C_{n}}\left[1-\frac{1}{(1+I R R)^{N}}\right]
$$




\subsection{Exergoenvironmental Analysis}

To investigate the system from the combination of exergy and environmental perspective, exergoenvironmental analysis is considered. The exergoenvironment factor which is affected by the exergy destruction rate is shown below [87-89]:

$$
f_{e i}=\frac{\dot{\mathrm{E}}_{D}}{\sum \dot{\mathrm{E}}_{i n}}
$$

In equation (35), subscripts $D$ and in are destruction and input. The environmental damage effectiveness factor can be calculated as [87-89]:

$$
\Theta_{e i}=f_{e i} \cdot C_{e i}
$$

$C_{e i}$ is the exergoenvironmental impact coefficient which is calculated by [87-89]:

$$
C_{e i}=\frac{1}{\eta_{e x}}
$$

In equation (37), $\eta_{e x}$ is the system exergy efficiency. The exergoenvironmental impact is expressed as [87-89]:

$$
\Theta_{e i i}=\frac{1}{\Theta_{e i}}
$$

The exergy stability factor is given by [87-89]:

$$
f_{e s}=\frac{\dot{\mathrm{E}}_{D}}{\dot{\mathrm{E}}_{\text {out }}+\dot{\mathrm{E}}_{D}+1}
$$

\subsection{Environmental Analysis}

To establish the relation between environmental air pollution and economics, the social cost of air pollution is considered. The social cost of air pollution is the cost associated with the harmful 
effects of air pollution on society. These effects are including diseases, deaths, etc. This cost can vary from one region to another. Also, the standard of living affects this cost. Further explanations are provided in ref. [90, 91].

The air pollution factors are not limited to these categories. Other sources of pollution such as water, soil, and noise... are existing that are ignored in this work because no data is existing in the literature, and the effects of these pollutions are much lower than air pollution.

In addition, during the components system production, various kinds of environmental pollution are produced that are out of the scope of this work. The environmental pollution produced during the operation time is related to life cycle analysis (LCA) and it can be investigated in future research $[90,91]$.

In order to establish a relationship between the environmental pollution and economics direct/indirect effect, four scenarios are considered. In all scenarios, it is assumed that the same amount of electrical power produced by the proposed system in this work, is produced by nonrenewable energy resource power production systems. These scenarios are as follows:

Scenario I: Natural gas-fueled gas turbine power plant

Scenario II: Gas oil-fueled gas turbine power plant

Scenario III: Coal-fired steam power plant

Scenario IV: Natural gas-fueled gas turbine with heat recovery boiler and steam turbine

The social cost of air pollution for carbon dioxide $\left(\mathrm{CO}_{2}\right)$, nitrogen oxide (NOx), and sulfur dioxide $\left(\mathrm{SO}_{2}\right)$ are presented in Table $12[90,91]$. The four scenarios with air pollution generation are shown in Table 13 [92]. 
Table 12. Social cost of air pollution for $\mathrm{CO}_{2}, \mathrm{NOx}$, and $\mathrm{SO}_{2}$

\begin{tabular}{|c|c|c|}
\hline Pollution & Unit & Values \\
\hline $\mathrm{CO}_{2}$ & \multirow{3}{*}{ US $\$ / \mathrm{kg}$} & 0.042 \\
\cline { 1 - 1 } $\mathrm{NO}_{\mathrm{x}}$ & & 7.3 \\
\cline { 1 - 1 } $\mathrm{SO}_{2}$ & & 7.4 \\
\hline
\end{tabular}

Table 13. Four scenarios and air pollution generation [92]

\begin{tabular}{|c|c|c|c|c|c|}
\hline Scenario & Power plant types & Fuel & $\begin{array}{c}\mathbf{C O}_{2} \\
(\mathbf{g} / \mathbf{k W h})\end{array}$ & $\begin{array}{c}\mathbf{N O} \\
(\mathbf{g} / \mathbf{k W h})\end{array}$ & $\begin{array}{c}\mathbf{S O}_{2} \\
(\mathbf{g} / \mathbf{k W h})\end{array}$ \\
\hline 1 & Gas turbine power plant & NG & 610 & 1.1 & - \\
\hline 2 & $\begin{array}{c}\text { Gas turbine power plant } \\
3\end{array}$ & $\begin{array}{c}\text { GO } \\
\text { plant }\end{array}$ & 800 & 1.6 & 1.4 \\
\hline 4 & $\begin{array}{c}\text { Gas turbine with heat } \\
\text { recovery boiler and } \\
\text { steam turbine }\end{array}$ & NG & 510 & 0.9 & - \\
\hline & Coal & 930 & 2.1 & 8.8 \\
\hline Abbreviations: NG: Natural gas; GO: Gas oil & & & \\
\hline
\end{tabular}

In the proposed system of this study, since the system does not produce any air pollution during the operation time, it can be considered as a benefit of this system. So, cogeneration annual income (CF) can be considered by the following expression to show the effect of the social cost of air pollution:

$$
\begin{gathered}
C F=Y_{\text {power }} k_{\text {power }}+Y_{\text {cooling }} k_{\text {cooling }}+Y_{\mathrm{PW}} k_{\mathrm{PW}}+Y_{\mathrm{NaCl}} k_{\mathrm{NaCl}} \\
+Y_{\mathrm{H} 2} k_{\mathrm{H} 2}+Y_{\mathrm{CO} 2} k_{\mathrm{CO} 2}+Y_{\mathrm{SO} 2} k_{\mathrm{SO} 2}+Y_{\mathrm{NO} x} k_{\mathrm{NOx}}
\end{gathered}
$$

where Y represents the annual air pollution generated by different scenarios depicted in Table 13, and $\mathrm{k}$ is the social cost of various air pollutions shown in Table 12. 


\section{Results and Discussion}

\subsection{Description of the Simulation Method}

After the mathematical modeling of the system, a computer program code was developed in engineering equation solver (EES) software. For the mixture of ammonia/water mixture properties calculation, the subroutine $\left(\mathrm{NH}_{3} \mathrm{H}_{2} \mathrm{O}\right)$ which is existing in the external library of the EES is used. Other working fluids' properties exist in EES software and they can be used easily by definition of thermodynamic function. The input information of the simulation program is depicted in Table 14.

Table 14. Input information of the simulation code

\begin{tabular}{|c|c|c|c|}
\hline Parameter & Unit & Value & Ref \\
\hline $\boldsymbol{X}_{\boldsymbol{I}}$ & - & 0.53 & {$[45]$} \\
\hline $\boldsymbol{X}_{\boldsymbol{4}}$ & - & 0.94 & {$[45]$} \\
\hline $\boldsymbol{X}_{5}$ & - & 0.99 & {$[45]$} \\
\hline$\dot{\boldsymbol{m}}_{\boldsymbol{I}}$ & $\mathrm{kg} / \mathrm{s}$ & 0.4 & - \\
\hline $\boldsymbol{T}_{\boldsymbol{I}}$ & $\mathrm{K}$ & 280 & {$[45]$} \\
\hline $\boldsymbol{T}_{5}$ & $\mathrm{~K}$ & 348 & {$[45]$} \\
\hline $\boldsymbol{T}_{7}$ & $\mathrm{~K}$ & 278 & {$[45]$} \\
\hline $\boldsymbol{P}_{\boldsymbol{I}}$ & $\mathrm{kPa}$ & 202.6 & {$[45]$} \\
\hline $\boldsymbol{P}_{2}$ & $\mathrm{kPa}$ & 3039 & {$[45]$} \\
\hline $\boldsymbol{x}_{16}$ & $\mathrm{mg} / \mathbf{l}$ & 40200 & {$[93]$} \\
\hline $\boldsymbol{x}_{27}$ & $\mathrm{mg} / \mathbf{l}$ & 150 & {$[93]$} \\
\hline $\boldsymbol{A}_{\boldsymbol{m}}$ & $\mathrm{m}{ }^{2}$ & 35.3 & {$[94]$} \\
\hline $\mathbf{R R}$ & - & 0.3 & {$[59]$} \\
\hline$\dot{\boldsymbol{m}}_{16}$ & $\mathrm{~kg} / \mathrm{s}$ & 2 & - \\
\hline
\end{tabular}

\subsection{Model Validation}

Since the whole plant has not been investigated yet, the validation of the whole plant by using experimental data is not feasible. Thus, each of the sub-systems has been validated individually. 
For validation of the combined power and cooling sub-systems (Goswami cycle), ref. [56] is considered. The input information of that reference is inserted into the computer simulation program. Table 15 shows the results of the comparison between the simulation model of this work with ref. [56].

Table 15. Results of the comparison between the simulation model with ref. [56]

\begin{tabular}{|c|c|c|c|c|c|}
\hline \multirow{2}{*}{ No. } & \multirow{2}{*}{$\mathbf{P}_{\mathbf{1}}(\mathbf{k P a})$} & \multirow{2}{*}{$\mathbf{P}_{\mathbf{2}}(\mathbf{k P a})$} & \multicolumn{3}{|c|}{$\eta_{\text {en }}$} \\
\cline { 4 - 6 } & & & Model & Ref[56] & Error(\%) \\
\hline 1 & 673.6 & 12124.8 & 3.54 & 3.5 & 1.2 \\
\hline 2 & 673.6 & 12798.4 & 2.98 & 2.8 & 4.2 \\
\hline 3 & 673.6 & 13472 & 2.36 & 2.2 & 2.5 \\
\hline
\end{tabular}

The comparison shows that the errors in the three situations are $1.2 \%, 4.2 \%$, and $2.5 \%$, respectively.

For validation of the RO system, the ref. [59] is considered. The data from the table of that reference is inserted into the computer code. Table 16 shows the comparison between the results of the RO system and ref. [59]. The minimum and maximum errors are $0.7 \%$ and $7 \%$, respectively. For validation of the $\mathrm{NaClO}$ plants, the ref. [81] is considered. The electrical power requirement of the $\mathrm{NaClO}$ plant is $4 \mathrm{~kW}$ while it is $3.78 \mathrm{~kW}$ in the computer code developed for this study. The error is around $5.5 \%$. The reason for this error is that the salt concentration in the feed mixture is unknown in ref. [81].

In conclusion, the developed computational code provides consistent results for each process subsystems, in agreement with the previously published data. 
Table 16. Comparison between the results of the RO system and ref. [59]

\begin{tabular}{|c|c|c|c|c|c|c|c|c|c|c|c|}
\hline \multicolumn{2}{|c|}{$\dot{\text { m}}_{\text {brain }}\left(\frac{\boldsymbol{k g}}{\boldsymbol{s}}\right)$} & \multicolumn{3}{c|}{$\dot{\mathrm{m}}_{P W}\left(\frac{k g}{s}\right)$} & \multicolumn{3}{c|}{$\dot{\mathrm{W}}_{\text {recovery turbine }}(\mathrm{kW})$} & \multicolumn{3}{c|}{$\dot{\mathrm{W}}_{P, \text { RO }}(k W)$} \\
\hline Model & Ref & Error(\%) & Model & Ref & Error(\%) & Model & Ref & Error(\%) & Model & Ref & Error(\%) \\
\hline 1.092 & 1.104 & 0.7 & 0.468 & 0.456 & 2.6 & 3.45 & 3.711 & 7 & 8.42 & 8.96 & 6 \\
\hline
\end{tabular}

\subsection{Energy and Exergy Analyses}

Table 17 shows the thermodynamic properties for each point of the system. Table 18 shows the annual system productions. By using this system, 1.075 GJ/year electrical energy, 1.04 GJ/year cooling energy, $18106.8 \mathrm{~m}^{3} /$ year potable water, 7.396 Ton/year hydrogen, and 3.838 Ton/year salt are produced annually. The cooling and electrical energy in the combined cooling and power system are close. The ratio of cooling to electrical energy is 0.97 (around unit).

Figure 3 shows the system power production in three configurations (Goswami, Goswami/RO, Goswami/RO/NaClO(global system)). It is clear that by adding the $\mathrm{RO}$ and $\mathrm{NaClO}$ plants to the system, power production declines to 36.78 and $37.09 \mathrm{~kW}$, respectively due to electrical power consumption of the $\mathrm{RO}$ and $\mathrm{NaClO}$ plants.

Figure 4 shows the energy and exergy efficiencies for three different configurations (Goswami, Goswami/RO, global system). It can be found that adding the RO system to the Goswami cycle increases the system energy efficiency from $10.2 \%$ to $12.4 \%$. From the energy point of view, although adding the RO system to the Goswami cycle reduces the electrical power production, the freshwater is also produced in the system $\left(\dot{\mathrm{m}}_{25} \mathrm{~h}_{25}\right)$. The amount of this increase overcomes the reduction of the electrical power consumed in the RO system, since it adds the energy rate of the fresh water to the numerator of energy efficiency. From an exergy point of view, adding the RO system to the Goswami cycle is not beneficial, since it reduces the exergy efficiency from $25.6 \%$ to $20.2 \%$. It means that the electrical power exergy rate has a higher value than the freshwater 
exergy rate. The reason for this phenomenon is that the RO system operates near the dead state $\left(25^{\circ} \mathrm{C}, 101.3 \mathrm{kPa}\right)$. So, the value of $\left(\dot{\mathrm{m}}_{25} \mathrm{e}_{25}\right)$ in equation 25 is low. Adding the $\mathrm{NaClO}$ plant to the Goswami/RO reduces the energy and exergy efficiencies slightly from $12.4 \%$ and $20.2 \%$ to $12.25 \%$ and $19.6 \%$, respectively. In both energy and exergy analyses, the penalty of consumed electrical power by the $\mathrm{NaClO}$ plant is higher than the products amount of energy and exergy. However, the small amount of electrical power consumed in $\mathrm{NaClO}$ plant compensates with the recovery turbine.

Table 17. Thermodynamic properties for each point of the system

\begin{tabular}{|c|c|c|c|c|c|}
\hline No. & $\dot{\mathbf{m}} \mathbf{( k g / s )}$ & $\mathbf{T}(\mathbf{K})$ & $\mathbf{P}(\mathbf{k P a})$ & $\begin{array}{c}\mathbf{h} \\
\mathbf{( k J} / \mathbf{k g})\end{array}$ & $\mathbf{e}(\mathbf{k J} / \mathbf{k g})$ \\
\hline 1 & 0.4 & 280 & 202.6 & -208.9 & -20.8 \\
\hline 2 & 0.4 & 282 & 3039 & -197 & -17.62 \\
\hline 3 & 0.4 & 287.4 & 3039 & -172.5 & -17.9 \\
\hline 4 & 0.4 & 373 & 3039 & 1287 & 320.7 \\
\hline 5 & 0.3429 & 348 & 3039 & 1273 & 324.1 \\
\hline 6 & 0.3429 & 378 & 3039 & 1437 & 361.3 \\
\hline 7 & 0.3429 & 278 & 202.6 & 1268 & -1.841 \\
\hline 8 & 0.3429 & 303 & 202.6 & 1364 & -0.6563 \\
\hline 9 & 0.05714 & 348 & 3039 & 132 & 26.04 \\
\hline 10 & 0.05714 & 305 & 3039 & -69.66 & 2.402 \\
\hline 11 & 0.05714 & 305 & 202.6 & 532.1 & -8.933 \\
\hline 12 & 15 & 393.2 & 202.6 & 503.8 & 52.1 \\
\hline 13 & 15 & 393.2 & 263.4 & 498.6 & 52.16 \\
\hline 14 & 15 & 391.9 & 255.5 & 444.7 & 50.9 \\
\hline 15 & 15 & 379.2 & 247.8 & 59.45 & 38.68 \\
\hline 16 & 2 & 298.2 & 101.3 & 59.45 & 13.46 \\
\hline 17 & 1 & 298.2 & 101.3 & 59.45 & 13.46 \\
\hline 18 & 1 & 298.2 & 101.3 & 63.69 & 13.46 \\
\hline 19 & 1 & 298.2 & 4767 & 63.69 & 17.98 \\
\hline 20 & 1 & 298.2 & 4767 & 67.49 & 17.98 \\
\hline 21 & 0.3 & 298.2 & 4767 & 61.83 & 4.659 \\
\hline 22 & 0.7 & 298.2 & 4767 & 67.49 & 6.596 \\
\hline 23 & 0.3 & 298.2 & 4767 & 61.83 & 4.659 \\
\hline 24 & 0.7 & 298.2 & 4767 & 67.49 & 6.596 \\
\hline 25 & 0.6 & 298.2 & 4767 & 63.05 & 4.659 \\
\hline 26 & 0.6 & 298.2 & 101.3 & 61.83 & 0.000242 \\
\hline 27 & 1.4 & 298.2 & 4767 & 57.84 & 6.596 \\
\hline 28 & 1.4 & 298.2 & 303.9 & 57.84 & 2.323 \\
\hline
\end{tabular}




\begin{tabular}{|c|c|c|c|c|c|}
29 & 0.014 & 298.2 & 101.3 & 3932 & 2.323 \\
\hline 30 & 0.0002568 & 298.2 & 101.3 & 3932 & 5491 \\
\hline 31 & 0.000133 & 312.2 & 101.3 & 274.7 & 0.8442 \\
\hline
\end{tabular}

Table 18. Annual system productions

\begin{tabular}{|l|l|r|}
\hline Product & Unit & \multicolumn{1}{c|}{ Values } \\
\hline $\mathbf{W}_{\text {net, }, \text { system }}$ & GJ/year & 1.0751 \\
\hline $\mathbf{Q}_{\text {cooling }}$ & GJ/year & 1.04 \\
\hline $\mathbf{V}_{\mathrm{PW}}$ & $\mathrm{m}^{3} /$ year & 18106.8 \\
\hline $\mathbf{m}_{\mathrm{NaCl}}$ & Ton/year & 3.838 \\
\hline $\mathbf{m}_{\mathrm{H} \mathbf{2}}$ & Ton/year & 7.396 \\
\hline
\end{tabular}

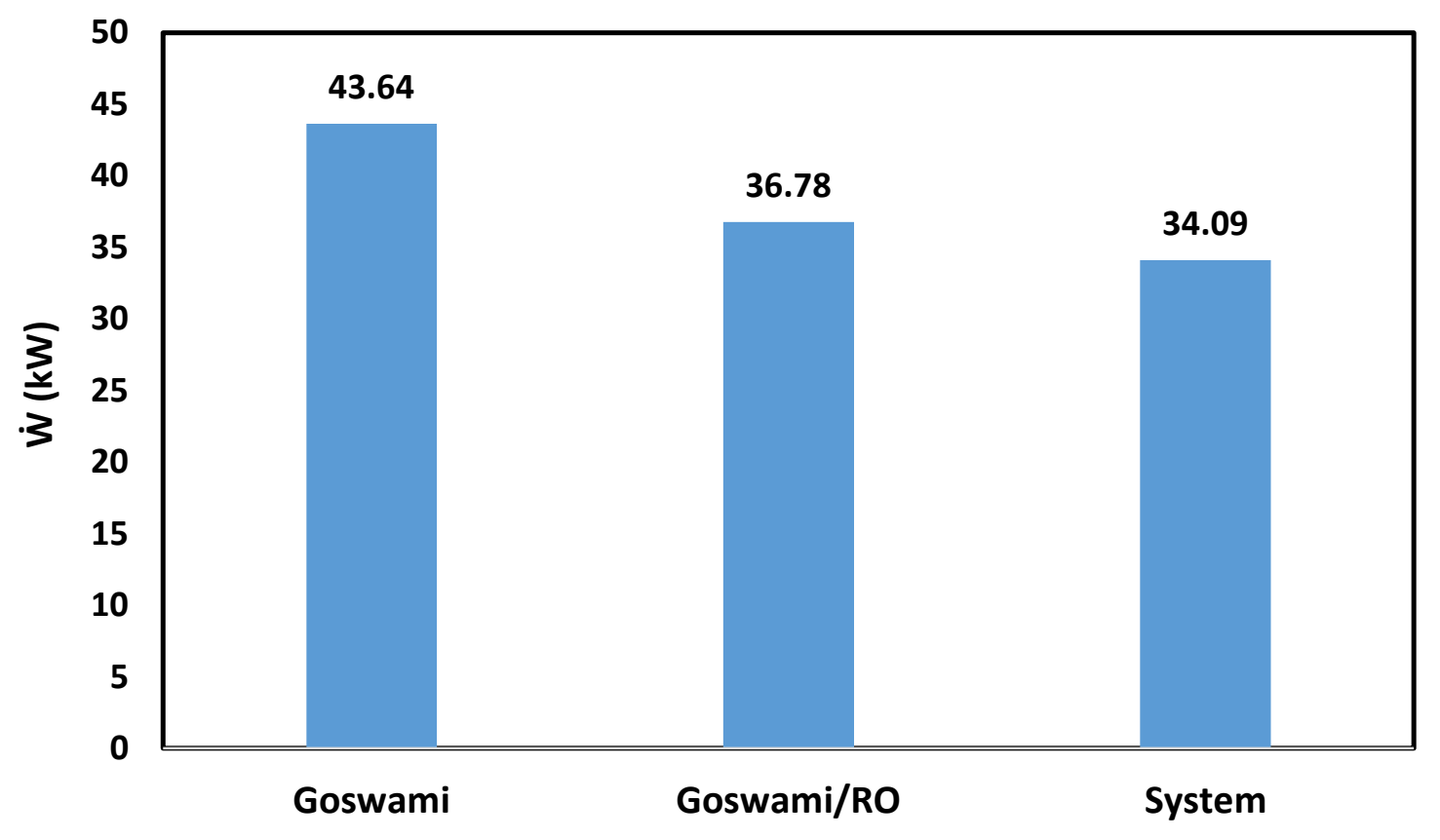

Figure 3. System power production in three configurations (Goswami, Goswami/RO, Goswami/RO/NaClO(system)) 


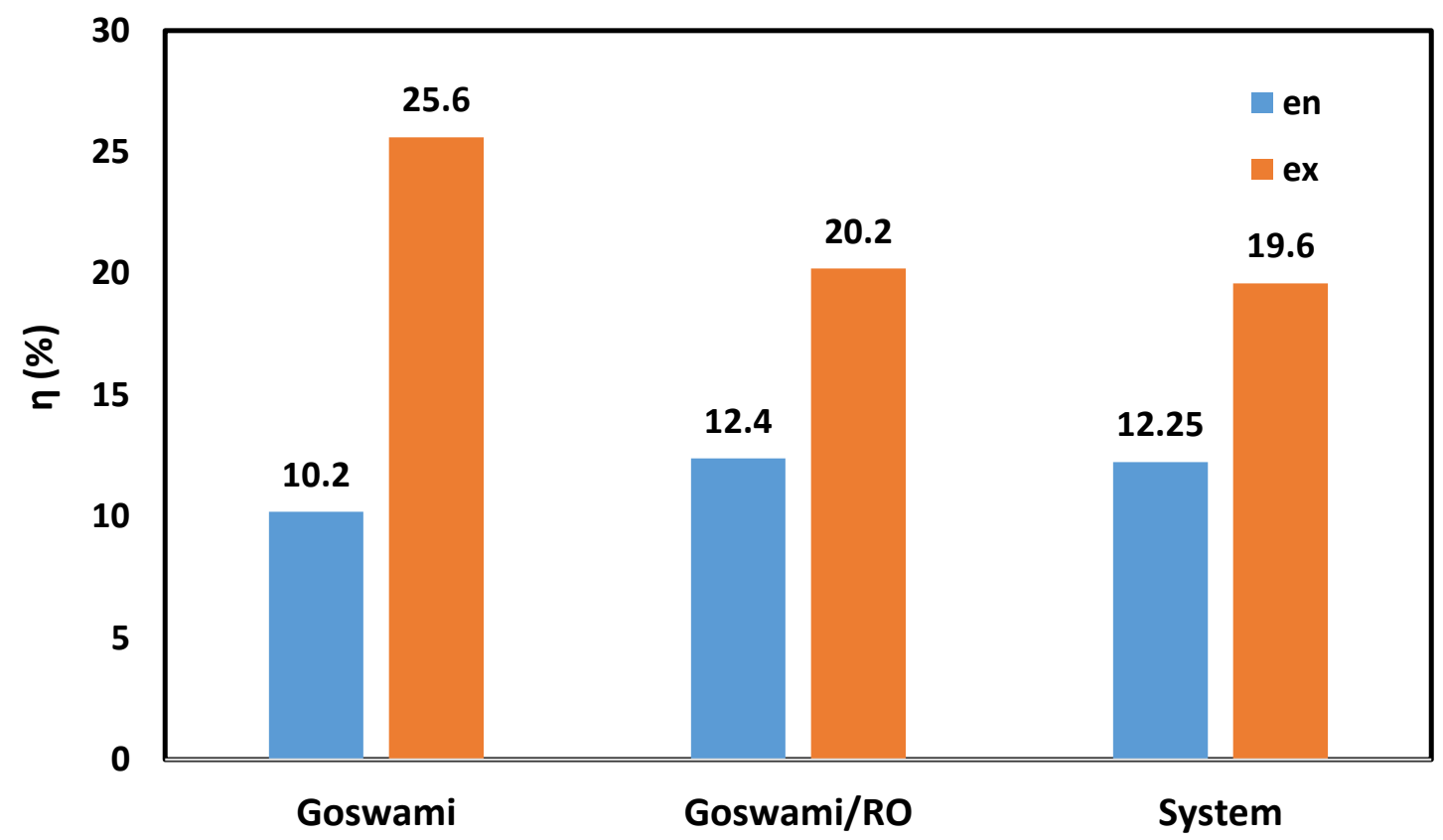

Figure 4. Energy and exergy efficiencies for three configurations (Goswami, Goswami/RO, global system)

Figure 5 shows the share of the exergy destruction rate for each subsystem. The maximum value is related to the Goswami cycle ( $87.31 \%)$. This is because this subsystem has the highest number of components and it operates at a temperature which is much higher than the two other subsystems. The RO plant has $11.04 \%$ of the total system exergy destruction rate. The reason is that the RO system operates at temperature $\left(25^{\circ} \mathrm{C}\right)$ near the dead state $\left(15^{\circ} \mathrm{C}, 101.3 \mathrm{kPa}\right)$. Furthermore, this system has a lower number of components than the Goswami cycle. The lowest portion of the total exergy destruction rate is related to the $\mathrm{NaClO}$ plant (1.65\%). The reason is that the mass flow rate of the brine water flowing through the $\mathrm{NaClO}$ plant is low. Similar to the RO system, this plant operates near the dead state. In general, the addition of these two sub-systems does not induce much exergy destruction on the system. 


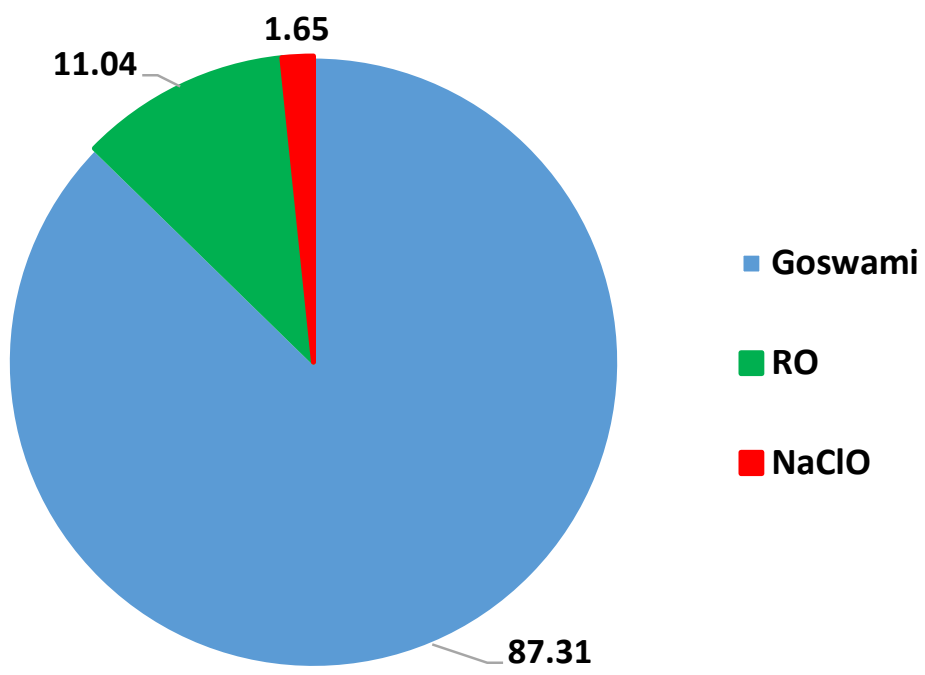

Figure 5. Share of the exergy destruction rate for each subsystem

\subsection{Economic Analysis Results}

Figure 6 shows the Net Present Value (NPV) from the Goswami, Goswami/RO, and total system, respectively. The NPV for the Goswami cycle is 0.826 million US dollars. Adding the RO system to the Goswami cycle is not beneficial considering this factor, because it decreases the NPV from 0.826 to 0.6 million US dollars. It means that the extra cost imposed on the system is higher than the product costs during the lifetime of this system. However, adding the $\mathrm{NaClO}$ plant is beneficial since the value of the NPV increased significantly from 0.6 to 3.1 (higher than five times). Unlike the RO system, in this case, the production benefits (salt and hydrogen) of the $\mathrm{NaClO}$ plant during the lifetime is higher than the initial cost. So, it can be concluded that producing $\mathrm{NaClO}$ and $\mathrm{H}_{2}$ is beneficial from the economic point of view. 


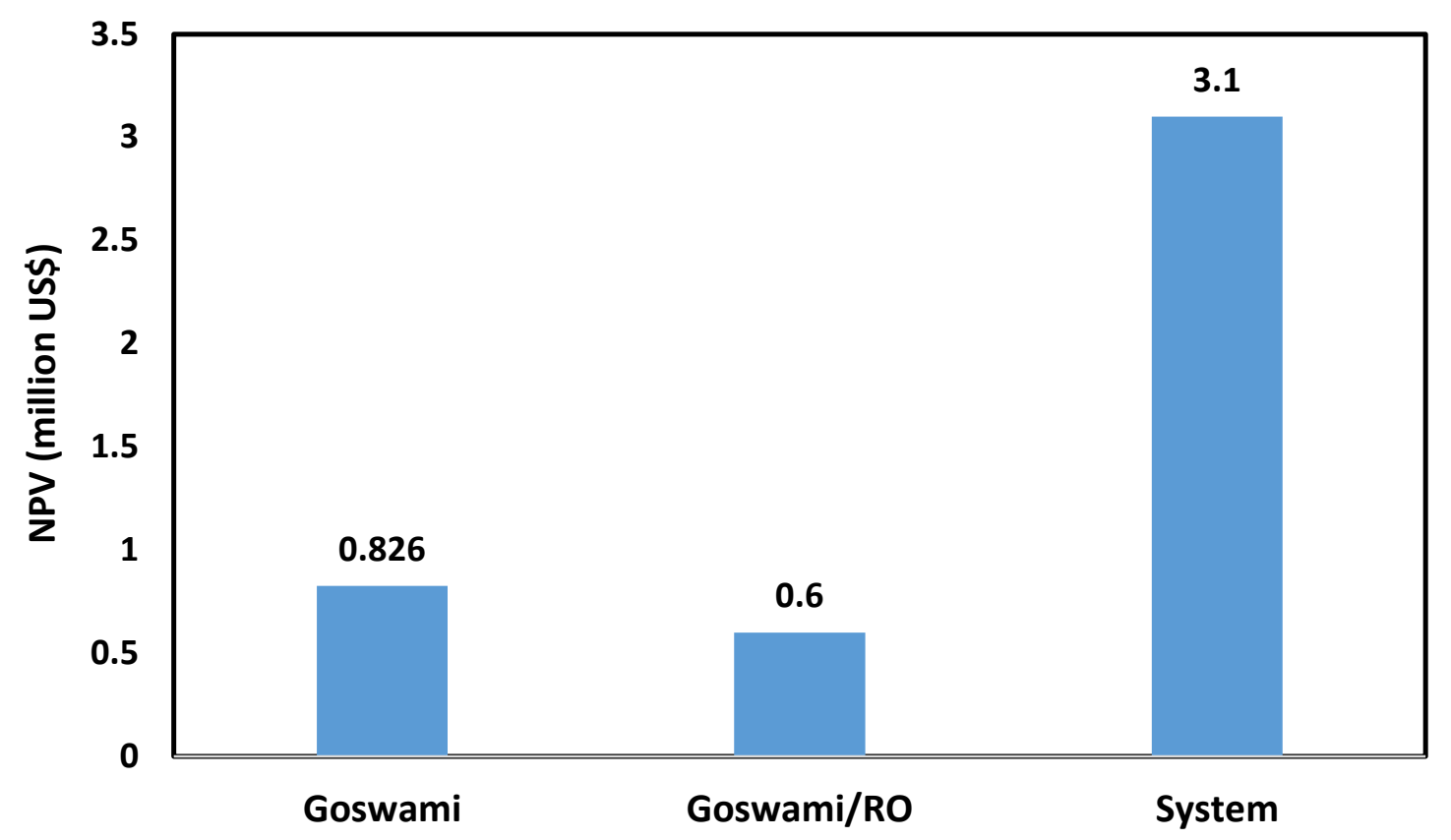

Figure 6. The NPV from the Goswami, Goswami/RO, and total system

The values of the Payback Period (PP) and Simple Payback Period (SPP) are shown in Figure 7. Adding the RO system to the Goswami cycle increases the PP and SPP from 4.26 and 3.95 years to 8.86 and 7.68 years, respectively. But adding the $\mathrm{NaClO}$ plant decreases these values. In general, the total system PP and SPP (2.7 and 2.56 years) are lower than the Goswami cycle and combination of Goswami and RO.

Figure 8 shows the internal rate of return for the Goswami, Goswami/RO, and the total system. By adding the RO system to the Goswami cycle, the IRR is reduced from 0.25 to 0.12 . This reduction is not appropriate. Adding the $\mathrm{NaClO}$ plant to Goswami/RO system compensates this reduction (0.12 to 0.39$)$.

From the economic analysis, it is clear that the $\mathrm{RO}$ system should be combined with the $\mathrm{NaClO}$ plant to bring more benefit to the system. 


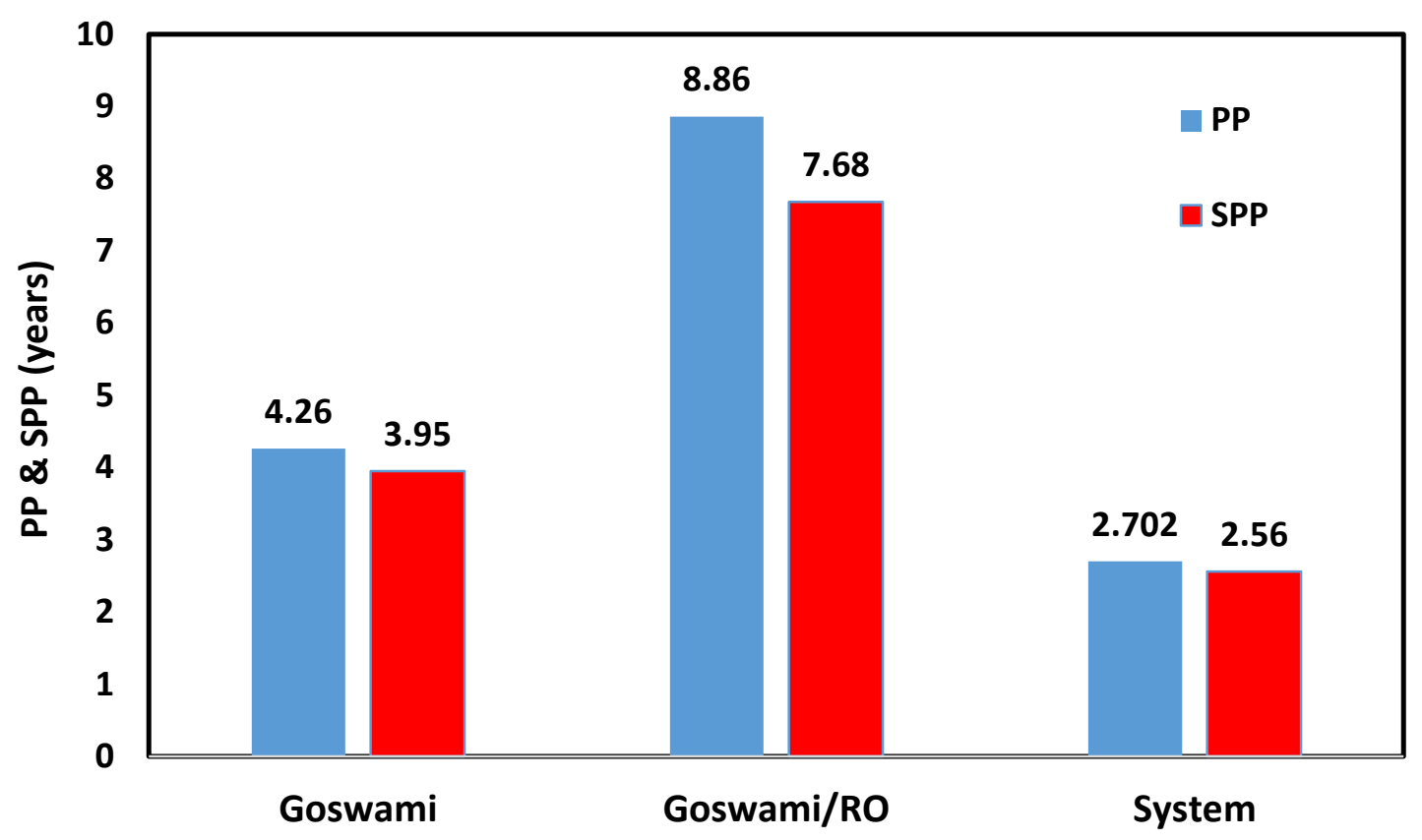

Figure 7. Values of PP and SPP for the Goswami, Goswami/RO, and the total system

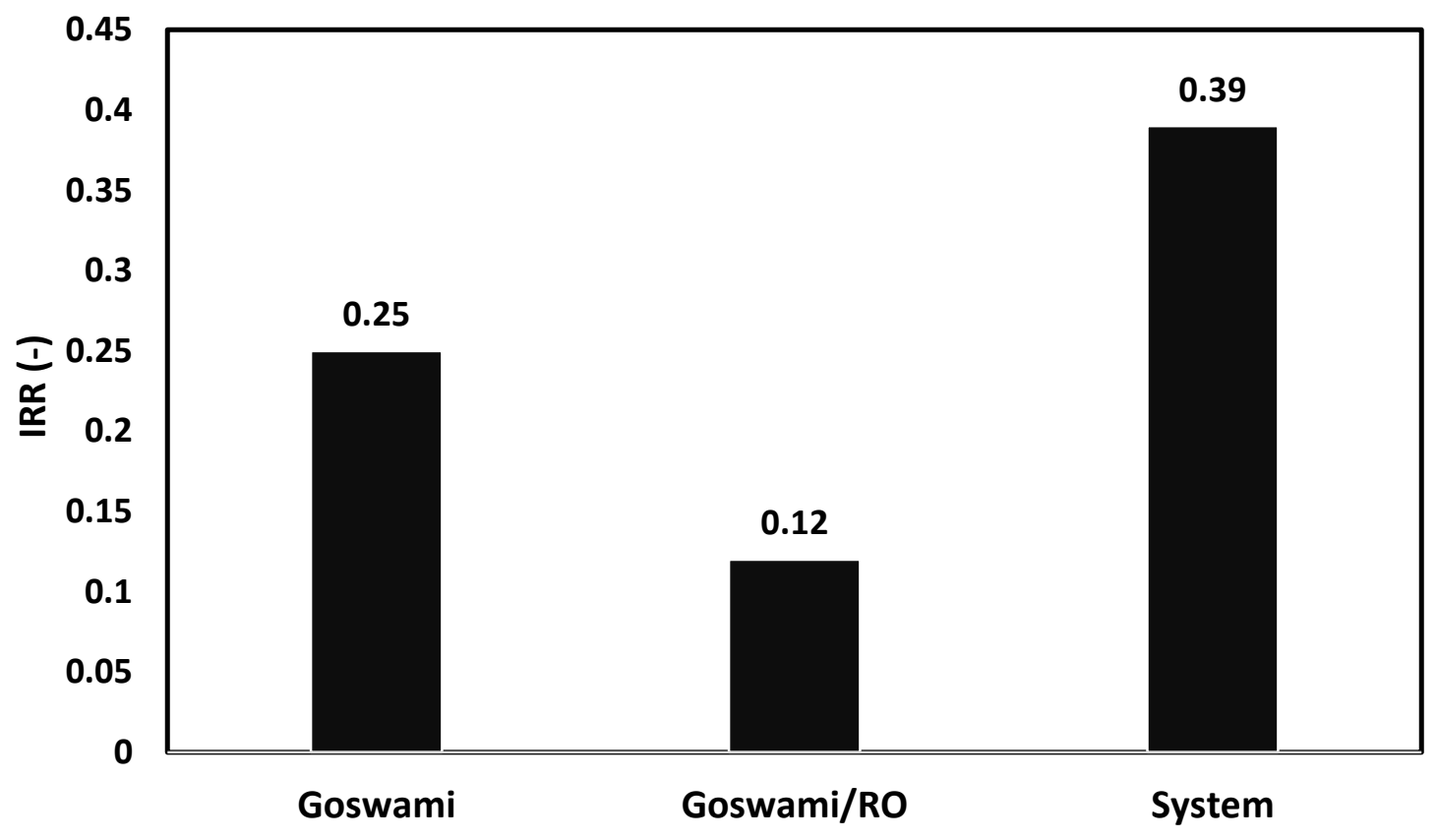

Figure 8. Internal rate of return for the Goswami, Goswami/RO, and the total system 


\subsection{Exergoenvironmental Analysis Results}

Figure 9 shows three exergoenvironmental factors (exergoenvironment $\left(\mathrm{f}_{\mathrm{ei}}\right)$, environmental damage effectiveness $\left(\theta_{e i}\right)$, and exergy stability $\left(\mathrm{f}_{\mathrm{es}}\right)$ ) for three configurations (Goswami, Goswami/RO, and total system), respectively.

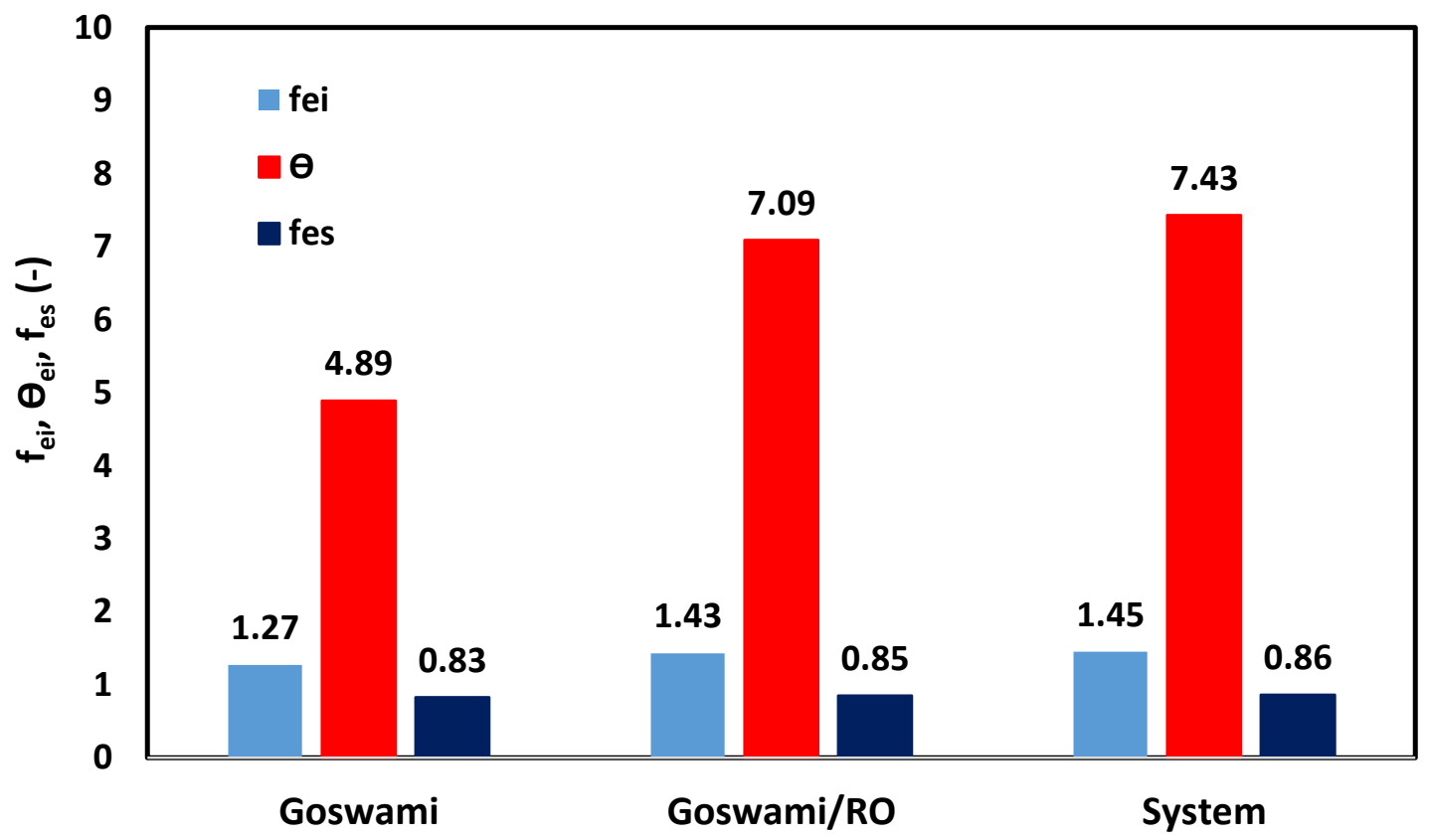

Figure 9. Exergoenvironment $\left(\mathrm{f}_{\mathrm{ei}}\right)$, environmental damage effectiveness $\left(\theta_{e i}\right)$, and exergy stability ( $\left.\mathrm{f}_{\mathrm{es}}\right)$ ) factors for three configurations (Goswami, Goswami/RO, and total system)

The exergoenvironment factor $\left(\mathrm{f}_{\mathrm{ei}}\right)$ increases by adding the $\mathrm{RO}$ and $\mathrm{NaClO}$ plant. If equation 35 is considered, it is clear that the denominator of this equation is the same for all three configurations, since in all three states, the energy resource is geothermal energy. However, the numerator of this equation is increased and each system added to the Goswami cycle has an exergy destruction rate. The trend of the environmental damage effectiveness factor $\left(\theta_{e i}\right)$ is similar to the exergoenvironmental factor $\left(f_{\mathrm{ei}}\right)$, since the exergy efficiency of the system does not improve by adding the $\mathrm{RO}$ and $\mathrm{NaClO}$ plants. Thus, this factor is increased due to higher exergy destruction rate and lower exergy efficiency.

The exergy stability factor is increased from 0.83 to 0.85 and 0.86 , by adding the $\mathrm{RO}$ and $\mathrm{NaClO}$ systems to the Goswami cycle. It means that the exergy stability factor for Goswami, Goswami/RO, and the total system are $0.83,0.85$, and 0.86 , respectively. This increase is however 
not considerable. Considering the related equation (equation 36), it can be concluded that the amount of exergy destruction rate added to the Goswami cycle is higher than the output exergy of the added system. It means that the output exergy of the $\mathrm{RO}$ and $\mathrm{NaClO}$ system cannot compensate for the exergy destruction produced in these systems.

\subsection{Environmental Analysis Results}

As mentioned before in the environment section, four scenarios are considered for environmental evaluations.

Figure 10 shows the amount of $\mathrm{CO}_{2}, \mathrm{SO}_{2}, \mathrm{NO}_{x}$ produced by the four scenarios if producing the same amount of electrical power generated by the proposed system in this work. The maximum amount of pollution is related to carbon dioxide $\left(\mathrm{CO}_{2}\right)$. The highest amount of $\mathrm{CO}_{2}$ is related to the third scenario (coal-fired power plant) and the minimum amount of $\mathrm{CO}_{2}$ is related to the fourth scenario (gas turbine with heat recovery boiler and back-pressure steam turbine). Similar to $\mathrm{CO}_{2}$, the maximum and minimum amounts of $\mathrm{NO}_{\mathrm{x}}$ are related to the third and fourth scenarios.

The first and fourth scenarios do not exhibit any sulfur dioxide production. The maximum amount of $\mathrm{SO}_{2}$ is related to the third scenario.

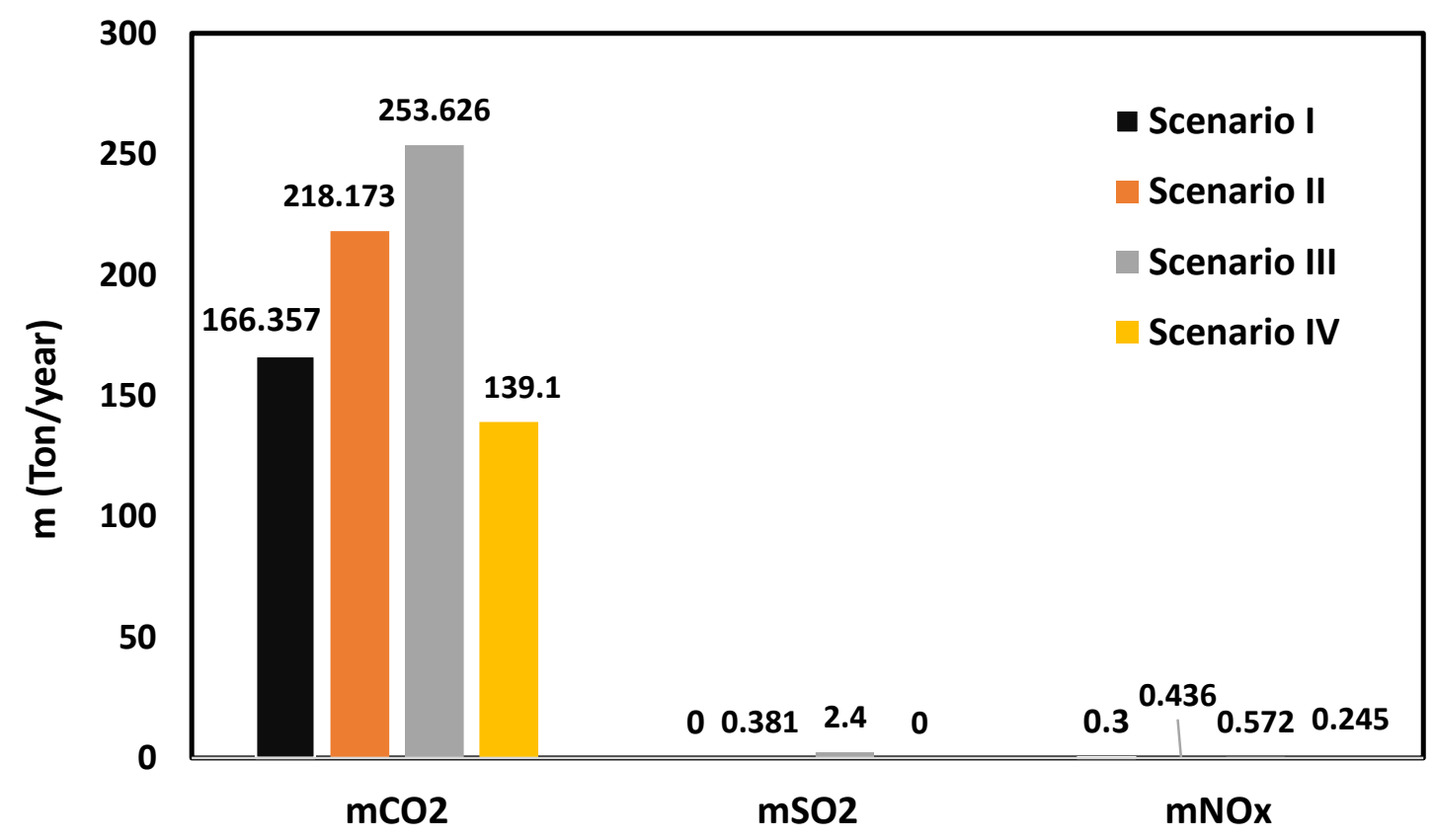

Figure 10. Amount of $\mathrm{CO}_{2}, \mathrm{SO}_{2}, \mathrm{NO}_{\mathrm{x}}$ produced in the four scenarios 
As mentioned before, if the social cost of air pollutions generated by the four scenarios is considered in the economic investigation, due to the absence of air pollution produced by the proposed system in this work, the economic factors (NPV, PP, SPP, IRR) are changed considerably.

Figure 11 shows the amount of NPV if the social cost of air pollution by each scenario is considered. The third scenario displays the maximum amount of NPV, since this scenario generates the maximum amount of air pollution in comparison with other scenarios.

Assuming that the same electrical power of the proposed system is produced by the third scenario and considering the social cost of air pollution, the NPV is changed from 3.1 million US\$ to 3.58 million US\$. If the first, second, and fourth scenarios are considered, this value is changed to 3.17, 3.28 , and 3.17 million US\$, respectively. It can be concluded that by inserting the social cost of air pollution, the multigeneration system powered by renewable energy is more beneficial.

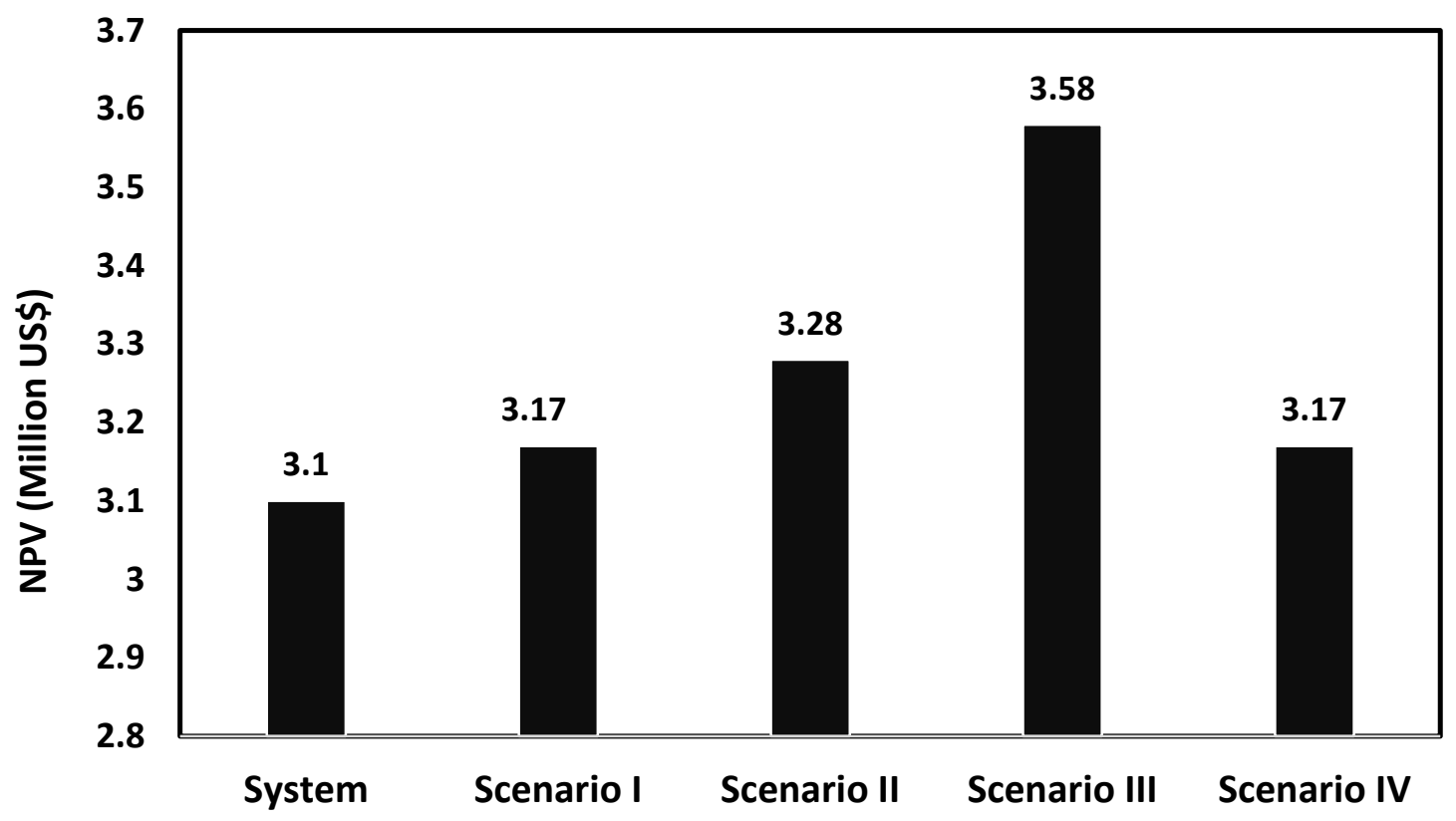

Figure 11. Amount of NPV considering the social cost of air pollution by the four scenarios

Figure 12 shows the comparison of PP and SPP between the system and scenarios I to IV when these scenarios produce the same amount of electrical power. By considering the social cost of air pollution, the amounts of PP and SPP are reduced. For example, if the third scenario is considered, 
the amount of PP and SPP are reduced from 2.7 and 2.56 years to 2.32 and 2.2 years, respectively. The various amounts of the IRR for the system and four scenarios are shown in Figure 13. The same results can be observed in this figure too. By considering the social cost of air pollution, this factor is improved from 0.39 to $0.41,0.42,0.45$, and 0.41 for the first to fourth scenario, respectively. The maximum amount of IRR is related to the third scenario that relies on the coal power plant with the highest air pollution impact.

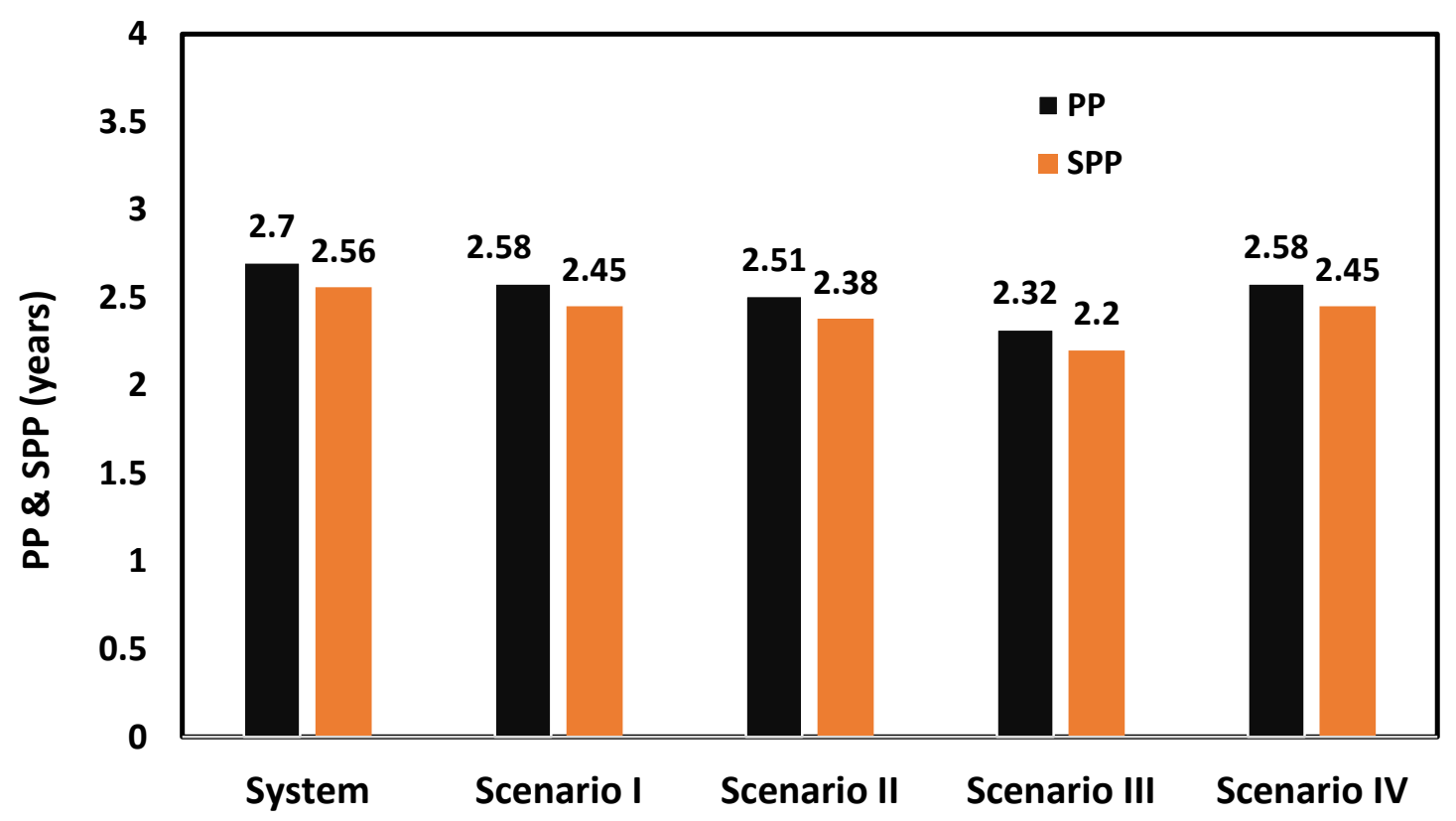

Figure 12. Comparison of PP and SPP between the system and scenarios I to IV 


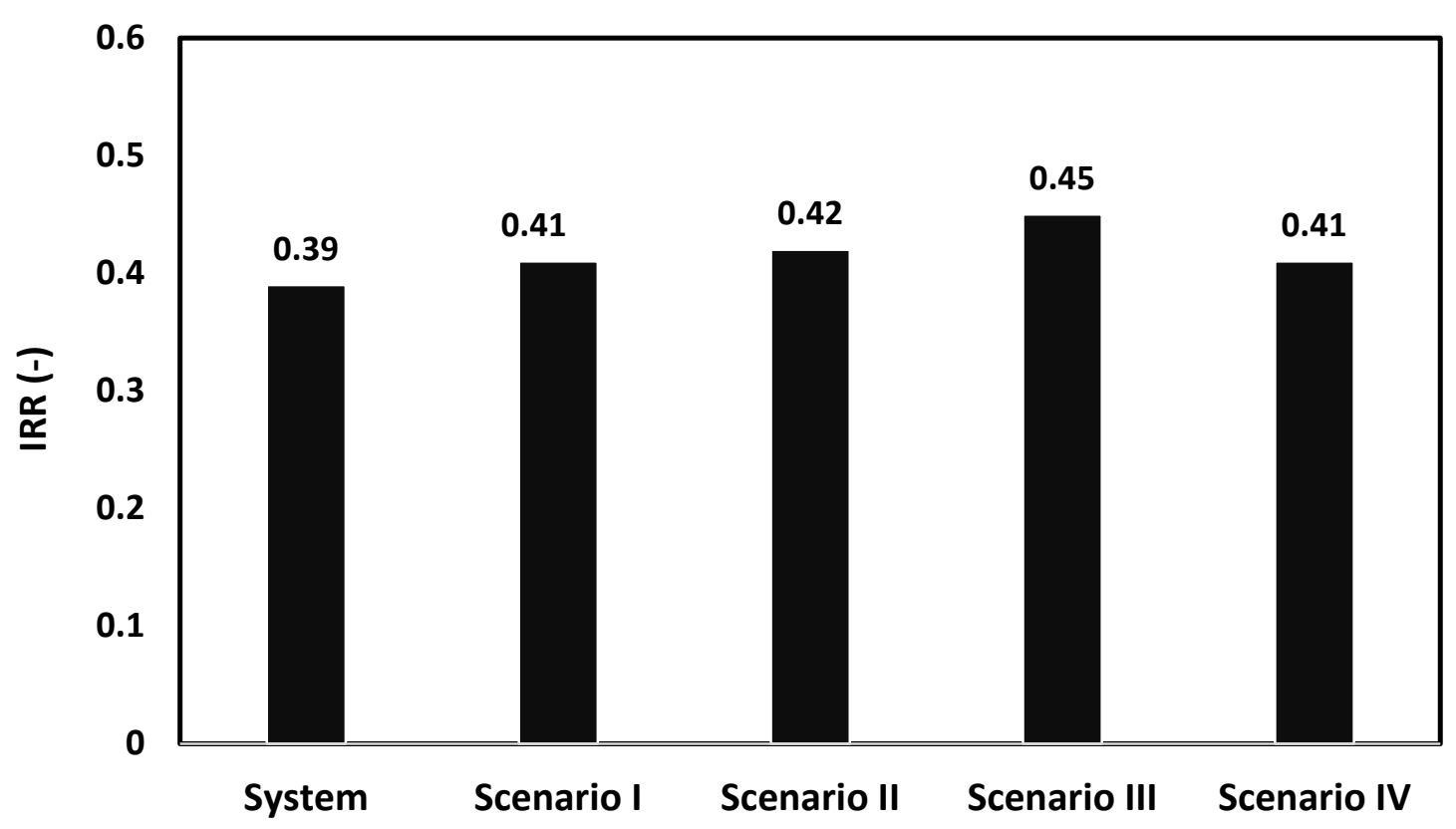

Figure 13. IRR for the system and four scenarios

In general, it can be concluded that if the social cost of air pollution or other sources of pollution is considered in the economic evaluation of the renewable energy powered systems, such multigeneration systems are more economical.

\section{Conclusion}

This study investigated a combined cogeneration system including the combined power and cooling system (Goswami cycle), Reverse Osmosis (RO), and $\mathrm{NaClO}$ production plant. The products of this system are electrical and cooling energy, potable water, hydrogen, and $\mathrm{NaClO}$ (salt).

The energy, exergy, economic, exergoenvironmental, and environmental analyses were conducted in this work to assess all of the aspects of this system. For the environmental analysis and establishment of a relationship between environmental pollutions and economics, the social cost of air pollution was considered. In this regard, four scenarios were defined. It is assumed the same amount of electrical power is produced by the non-renewable energy resource power production systems. These systems are gas turbines with natural gas and gas oil fuels, coal fired steam power plants, and natural gas fueled gas turbines with heat recovery boiler and backpressure steam turbine. 
The air pollutions generated by these systems are estimated by typical data existing in literature. By considering these social costs as benefits for this proposed system due to the absence of air pollution produced during the operation time, the environmental effect can be highlighted.

Summly, the main results of this research are as follows:

- This system produces 1.075 GJ/year electrical energy, 1.04 GJ/year cooling energy, $18106.8 \mathrm{~m}^{3} /$ year potable water, 7.396 Ton/year hydrogen, and 3.838 Ton/year salt are produced annually.

- The system energy efficiency for the Goswami, Goswami/RO, and the total system are equal to $10.2 \%, 12.4 \%$, and $12.25 \%$, respectively.

- The system exergy efficiency for the Goswami, Goswami/RO, and the total system are equal to $25.6 \%, 20.2 \%$, and $19.6 \%$, respectively.

- The share of the exergy destruction rate for the Goswami cycle, $\mathrm{RO}$, and $\mathrm{NaClO}$ plant are $87.3 \%, 11.04 \%$, and $1.65 \%$, respectively.

- The system NPV, PP, SPP, IRR are equal to 3.1 million US\$, 2.7 years, 2.56 years, and 0.39 , respectively.

- The $\mathrm{f}_{\mathrm{ei}}, \Theta_{\mathrm{ei}}, \mathrm{f}_{\mathrm{es}}$ for the total system are $1.45,7.43$, and 0.86 , respectively.

- Adding the $\mathrm{NaClO}$ plant to the system is appropriate from economic point of view.

- By considering the social cost of air pollution in economic evaluation, the renewable energy resource multi-generation systems can be more economical.

\section{Nomenclature}

\section{Abbreviation}

Definition

AFC

ASR

CPVT

DHW

ED

ESC

FC

FGPP
Ammonia fuel cell

Absorption refrigeration

Concentrated Photovoltaics/Thermal

Domestic Hot Water

Electrodialysis, Electrolyzer

Evacuated Solar Collector

Fuel Cell

Flash-Binary Geothermal Power Plant 


\begin{tabular}{|c|c|c|}
\hline GO & \multicolumn{2}{|c|}{ Gas Oil } \\
\hline HDH & \multicolumn{2}{|c|}{ Humidification-Dehumidification unit } \\
\hline KC & \multicolumn{2}{|c|}{ Kalina Cycle } \\
\hline LCOE & \multicolumn{2}{|c|}{ Levelized Cost of Electricity } \\
\hline LCOW & \multicolumn{2}{|c|}{ Levelized Cost of water } \\
\hline MD & \multicolumn{2}{|c|}{ Membrane Distillation } \\
\hline MED & \multicolumn{2}{|c|}{ Multi-Effect Distillation } \\
\hline MSF & \multicolumn{2}{|c|}{ Multi-Stage Flash Distillation } \\
\hline NG & \multicolumn{2}{|c|}{ Natural Gas } \\
\hline ORC & \multicolumn{2}{|c|}{ Organic Rankin Cycle } \\
\hline PCM & \multicolumn{2}{|c|}{ Phase Change Material } \\
\hline PEMFC & \multicolumn{2}{|c|}{ Proton Exchange Membrane Fuel Cell } \\
\hline PRO & \multicolumn{2}{|c|}{ Pressure Retarded Osmosis } \\
\hline PTC & \multicolumn{2}{|c|}{ Parabolic Through Collector } \\
\hline PV & \multicolumn{2}{|c|}{ Photovoltaic } \\
\hline RHE & \multicolumn{2}{|c|}{ Refrigeration Heat Exchanger } \\
\hline RHX & \multicolumn{2}{|c|}{ Recovery Heat Exchanger } \\
\hline RO & \multicolumn{2}{|c|}{ Reverse Osmosis } \\
\hline SC & \multicolumn{2}{|c|}{ Steam Cycle } \\
\hline SD & \multicolumn{2}{|c|}{ Solar Dish } \\
\hline SSE & \multicolumn{2}{|c|}{ Single Stage Evaporator } \\
\hline SUCP & \multicolumn{2}{|c|}{ Sum Unit Cost of Product } \\
\hline TES & \multicolumn{2}{|c|}{ Thermal Energy Storage } \\
\hline TGOR & \multicolumn{2}{|c|}{ Trigeneration-based Gain-Output-Ratio } \\
\hline VC & \multicolumn{2}{|c|}{ Vapor-Compression Evaporation } \\
\hline Symbols & & Definition \\
\hline $\mathbf{A}$ & $\mathrm{m}^{2}$ & Area \\
\hline $\mathrm{C}_{\mathbf{0}}$ & US\$ & System investment cost \\
\hline $\mathrm{C}_{\mathrm{ei}}$ & - & Exergoenvironmental impact coefficient \\
\hline $\mathbf{C}_{\mathbf{n}}$ & US\$ & $\begin{array}{l}\text { System investment cost in the specific year } \\
\text { with considering inflation rate }\end{array}$ \\
\hline $\mathbf{C F}$ & US\$ & Cogeneration annual income \\
\hline D & $\mathrm{m}$ & Diameter \\
\hline e & $\mathrm{kJ} / \mathrm{kg}$ & Specific exergy \\
\hline$\dot{\mathrm{E}}$ & $\mathrm{kW}$ & Exergy rate \\
\hline
\end{tabular}




\begin{tabular}{|c|c|c|}
\hline $\mathbf{f}_{\text {ei }}$ & - & Exrgroenvironment factor \\
\hline $\mathbf{f}_{\mathrm{es}}$ & - & Exergy stability factor \\
\hline $\mathbf{F}_{\mathbf{t}}$ & - & Correction factor \\
\hline g & $\mathrm{m} / \mathrm{s}^{2}$ & Gravitational acceleration \\
\hline $\mathbf{h}$ & $\mathrm{kJ} / \mathrm{kg}$ & Specific enthalpy \\
\hline IRR & - & Internal rate of return \\
\hline $\mathbf{k}$ & $\mathrm{US} \$ / \mathrm{kWh}$ & Products specific cost \\
\hline $\mathbf{K}$ & US\$ & $\begin{array}{l}\text { Investment and installation cost of each } \\
\text { subsystem }\end{array}$ \\
\hline $\mathbf{K}_{\mathbf{w}}$ & $1 / \mathrm{K}$ & Water permeability coefficient \\
\hline$\dot{\mathbf{m}}$ & $\mathrm{kg} / \mathrm{s}$ & Mass flow rate \\
\hline $\mathbf{N}$ & Years & Lifetime of the project \\
\hline NPV & US\$ & Net Present Value \\
\hline $\mathbf{P}$ & $\mathrm{kPa}$ & Pressure \\
\hline PP & Years & Payback Period \\
\hline$\dot{\mathbf{Q}}$ & $\mathrm{kW}$ & Heat transfer rate \\
\hline $\mathbf{r}$ & - & Discount factor \\
\hline $\mathbf{R}$ & $\mathrm{kJ} / \mathrm{kmoleK}$ & Global gas constant \\
\hline $\mathbf{R R}$ & - & Recovery ratio \\
\hline $\mathbf{s}$ & $\mathrm{kJ} / \mathrm{kgK}$ & Specific entropy \\
\hline SPP & Years & Simple Payback Period \\
\hline $\mathbf{T}$ & ${ }^{\circ} \mathrm{C} / \mathrm{K}$ & Temperature \\
\hline $\mathbf{U}$ & $\mathrm{W} / \mathrm{m}^{2} \mathrm{~K}$ & Overall heat transfer coefficient \\
\hline $\mathbf{V}$ & $\mathrm{m} / \mathrm{s}, \mathrm{m}^{3}$ & Velocity, Volume \\
\hline$\dot{\mathbf{w}}$ & $\mathrm{kW}$ & Work transfer rate \\
\hline$x$ & - & Concentration of salt, Mass fraction \\
\hline$X$ & - & Ammonia mass ratio \\
\hline $\mathbf{y}$ & - & Mole fraction \\
\hline $\mathbf{Y}$ & US $\$ / \mathrm{kWh}, \mathrm{US} \$ / \mathrm{kg}$ & Annual capacity of system productions \\
\hline $\mathbf{z}$ & $\mathrm{m}$ & Height, Depth of geothermal well \\
\hline \multicolumn{3}{|c|}{ Greek Symbols } \\
\hline$\eta$ & - & Polythrophic efficiency \\
\hline$\Delta \pi$ & $\mathrm{kPa}$ & Net-pressure membrane \\
\hline$\theta_{\mathbf{e i}}$ & - & Environmental damage effectiveness factor \\
\hline
\end{tabular}




$\begin{array}{lll}\theta_{\text {eii }} & \text { Subscripts } & \\ \text { 0 } & \text { Dead state } \\ \text { BW } & \text { Brain water } \\ \text { ch } & \text { Chemical } \\ \text { D } & \text { Destruction } \\ \text { en } & \text { Energy } \\ \text { ex } & \text { Exergy } \\ \text { f } & \text { Formation } \\ \text { i } & \text { Species } \\ \text { in } & \text { Inlet } \\ \text { out } & \text { Outlet } \\ \text { m } & \text { Membrane } \\ \text { P } & \text { Product, Pump } \\ \text { PW } & \text { Potable water } \\ \text { R } & \text { Reactant } \\ \text { Sep } & \text { Seperator } \\ \text { SW } & \text { Seawater } \\ \text { T } & \text { Turbine }\end{array}$

\section{Exergoenvironmental impact}

\section{Definition}

Dead state

Brain water

ical

Formation

Species

Potable water

Reactant

Seperator

ate

\section{References}

[1] The Global Risks Report 2019, weforum.org/reports/the-global-risks-report-2019 [Access 03.06.2020], in, 2019.

[2] M. Ehyaei, S. Hakimzadeh, N. Enadi, P. Ahmadi, Exergy, economic and environment (3E) analysis of absorption chiller inlet air cooler used in gas turbine power plants, International Journal of Energy Research, 36 (2012) 486-498.

[3] M.M. Mekonnen, A.Y. Hoekstra, Four billion people facing severe water scarcity, Science Advances, 2 (2016) e1500323.

[4] How do we prevent today's water crisis becoming tomorrow's catastrophe? weforum.org/agenda/2017/03/building-freshwater-resilience-to-anticipate-and-address-water-crises [Access 03.06.2020]

in, 2017.

[5] C.J. Vörösmarty, P. Green, J. Salisbury, R.B. Lammers, Global Water Resources: Vulnerability from Climate Change and Population Growth, Science, 289 (2000) 284-288.

[6] R.G. Raluy, L. Serra, J. Uche, A. Valero, Life-cycle assessment of desalination technologies integrated with energy production systems, Desalination, 167 (2004) 445-458.

[7] A.D. Khawaji, J.-M. Wie, Potabilization of desalinated water at Madinat Yanbu Al-Sinaiyah, Desalination, 98 (1994) 135-146. 
[8] M. Al-Shammiri, M. Safar, Multi-effect distillation plants: state of the art, Desalination, 126 (1999) 4559.

[9] O.K. Buros, The ABCs of Desalting, in, International Desalination AssociationTopsfield, Massachusetts, USA, 2000.

[10] The Desalting and Water Treatment Membrane Manual: A Guide to Membranes for Municipal Water Treatment, Water Treatment Technology Program, Report No. 1, usbr.gov/research/dwpr/reportpdfs/report001.pdf [Access 03.06.2020], in, the United States Department of the Interior, Bureau of Reclamation, Denver Office, Research and Laboratory Services Division, Applied Sciences

Branch (R-93-15), 1993.

[11] A.D. Khawaji, I.K. Kutubkhanah, J.-M. Wie, Advances in seawater desalination technologies, Desalination, 221 (2008) 47-69.

[12] T. Xu, lon exchange membranes: State of their development and perspective, Journal of Membrane Science, 263 (2005) 1-29.

[13] J.E. Miller, Review of Water Resources and Desalination Technologies in, Sandia National Laboratories Albuquerque, New Mexico 87185 and Livermore, California 945502003.

[14] M.I.M. Shatat, Solar water desalination, in,

, School of Engineering, Durham University, UK, 2008.

[15] Water Desalination Technologies in the ESCWA Member Countries, in, United Nations. Economic and Social Commission for Western Asia, 2001.

[16] M.A. Darwish, H. El-Dessouky, The heat recovery thermal vapour-compression desalting system: A comparison with other thermal desalination processes, Applied Thermal Engineering, 16 (1996) 523-537.

[17] S. Karellas, A. Schuster, A. Leontaritis, Influence of supercritical ORC parameters on plate heat exchanger design, Applied Thermal Engineering, s 33-34 (2012) 70-76.

[18] S.A. Kalogirou, Seawater desalination using renewable energy sources, Progress in Energy and Combustion Science, 31 (2005) 242-281.

[19] W. Rice, D.S.C. Chau, Freeze desalination using hydraulic refrigerant compressors, Desalination, 109 (1997) 157-164.

[20] H. Chen, L. Wang, Chapter 8 - Posttreatment Strategies for Biomass Conversion, in: H. Chen, L. Wang (Eds.) Technologies for Biochemical Conversion of Biomass, Academic Press, Oxford, 2017, pp. 197-217.

[21] M.W. Shahzad, M. Burhan, L. Ang, K.C. Ng, Energy-water-environment nexus underpinning future desalination sustainability, Desalination, 413 (2017) 52-64.

[22] H. Mahmoudi, N. Ghaffour, M.F. Goosen, J. Bundschuh, Renewable energy technologies for water desalination, CRC Press, 2017.

[23] M.A. Ehyaei, A. Ahmadi, M. El Haj Assad, M.A. Rosen, Investigation of an integrated system combining an Organic Rankine Cycle and absorption chiller driven by geothermal energy: Energy, exergy, and economic analyses and optimization, Journal of Cleaner Production, 258 (2020) 120780.

[24] M. El Haj Assad, E. Bani-Hani, M. Khalil, Performance of geothermal power plants (single, dual, and binary) to compensate for LHC-CERN power consumption: comparative study, Geothermal Energy, 5 (2017) 17.

[25] H. Kianfard, S. Khalilarya, S. Jafarmadar, Exergy and exergoeconomic evaluation of hydrogen and distilled water production via combination of PEM electrolyzer, RO desalination unit and geothermal driven dual fluid ORC, Energy Conversion and Management, 177 (2018) 339-349.

[26] L. Ozgener, A. Hepbasli, I. Dincer, Energy and exergy analysis of the Gonen geothermal district heating system, Turkey, Geothermics, 34 (2005) 632-645.

[27] M.A. Abdelkareem, M. El Haj Assad, E.T. Sayed, B. Soudan, Recent progress in the use of renewable energy sources to power water desalination plants, Desalination, 435 (2018) 97-113. 
[28] V. Zare, A comparative thermodynamic analysis of two tri-generation systems utilizing low-grade geothermal energy, Energy Conversion and Management, 118 (2016) 264-274.

[29] O. Siddiqui, I. Dincer, A new solar and geothermal based integrated ammonia fuel cell system for multigeneration, International Journal of Hydrogen Energy, (2020).

[30] A. Mohammadi, M. Mehrpooya, Energy and exergy analyses of a combined desalination and CCHP system driven by geothermal energy, Applied Thermal Engineering, 116 (2017) 685-694.

[31] B. Ghorbani, A. Ebrahimi, M. Moradi, M. Ziabasharhagh, Energy, exergy and sensitivity analyses of a novel hybrid structure for generation of Bio-Liquefied natural Gas, desalinated water and power using solar photovoltaic and geothermal source, Energy Conversion and Management, 222 (2020) 113215.

[32] P. Behnam, A. Arefi, M.B. Shafii, Exergetic and thermoeconomic analysis of a trigeneration system producing electricity, hot water, and fresh water driven by low-temperature geothermal sources, Energy Conversion and Management, 157 (2018) 266-276.

[33] A. Colmenar-Santos, E. Palomo-Torrejón, F. Mur-Pérez, E. Rosales-Asensio, Thermal desalination potential with parabolic trough collectors and geothermal energy in the Spanish southeast, Applied Energy, 262 (2020) 114433.

[34] T. Gholizadeh, M. Vajdi, H. Rostamzadeh, A new trigeneration system for power, cooling, and freshwater production driven by a flash-binary geothermal heat source, Renewable Energy, 148 (2020) 31-43.

[35] S.A. Makkeh, A. Ahmadi, F. Esmaeilion, M.A. Ehyaei, Energy, exergy and exergoeconomic optimization of a cogeneration system integrated with parabolic trough collector-wind turbine with desalination, Journal of Cleaner Production, 273 (2020) 123122.

[36] A. Shekari Namin, H. Rostamzadeh, P. Nourani, Thermodynamic and thermoeconomic analysis of three cascade power plants coupled with RO desalination unit, driven by a salinity-gradient solar pond, Thermal Science and Engineering Progress, 18 (2020) 100562.

[37] A. Mouaky, A. Rachek, Thermodynamic and thermo-economic assessment of a hybrid solar/biomass polygeneration system under the semi-arid climate conditions, Renewable Energy, 156 (2020) 14-30.

[38] B. Ghorbani, R. Shirmohammadi, M. Mehrpooya, Development of an innovative cogeneration system for fresh water and power production by renewable energy using thermal energy storage system, Sustainable Energy Technologies and Assessments, 37 (2020) 100572.

[39] F. Calise, F.L. Cappiello, R. Vanoli, M. Vicidomini, Economic assessment of renewable energy systems integrating photovoltaic panels, seawater desalination and water storage, Applied Energy, 253 (2019) 113575.

[40] G. Filippini, M.A. Al-Obaidi, F. Manenti, I.M. Mujtaba, Design and economic evaluation of solarpowered hybrid multi effect and reverse osmosis system for seawater desalination, Desalination, 465 (2019) 114-125.

[41] N. Sezer, M. Koç, Development and performance assessment of a new integrated solar, wind, and osmotic power system for multigeneration, based on thermodynamic principles, Energy Conversion and Management, 188 (2019) 94-111.

[42] Q. Li, L.-J. Beier, J. Tan, C. Brown, B. Lian, W. Zhong, Y. Wang, C. Ji, P. Dai, T. Li, P. Le Clech, H. Tyagi, X. Liu, G. Leslie, R.A. Taylor, An integrated, solar-driven membrane distillation system for water purification and energy generation, Applied Energy, 237 (2019) 534-548.

[43] F. Xu, Analysis of a novel combined thermal power and cooling cycle using ammonia-water mixtures as a working fluid, in, University of Florida, 1997.

[44] G. Tamm, D.Y. Goswami, S. Lu, A.A. Hasan, Novel Combined Power and Cooling Thermodynamic Cycle for Low Temperature Heat Sources, Part I: Theoretical Investigation, Journal of Solar Energy Engineering, 125 (2003) 218-222.

[45] D.Y. Goswami, F. Xu, Analysis of a New Thermodynamic Cycle for Combined Power and Cooling Using Low and Mid Temperature Solar Collectors, Journal of Solar Energy Engineering, 121 (1999) 91-97. 
[46] G. Tamm, D.Y. Goswami, S. Lu, A.A. Hasan, Theoretical and experimental investigation of an ammonia-water power and refrigeration thermodynamic cycle, Solar Energy, 76 (2004) 217-228.

[47] A. Behzadi, E. Gholamian, P. Ahmadi, A. Habibollahzade, M. Ashjaee, Energy, exergy and exergoeconomic (3E) analyses and multi-objective optimization of a solar and geothermal based integrated energy system, Applied Thermal Engineering, 143 (2018) 1011-1022.

[48] S.M. Alirahmi, S. Rahmani Dabbagh, P. Ahmadi, S. Wongwises, Multi-objective design optimization of a multi-generation energy system based on geothermal and solar energy, Energy Conversion and Management, 205 (2020) 112426.

[49] R. Yargholi, H. Kariman, S. Hoseinzadeh, M. Bidi, A. Naseri, Modeling and advanced exergy analysis of integrated reverse osmosis desalination with geothermal energy, Water Supply, 20 (2020) 984-996.

[50] B.H. Gebreslassie, G. Guillén-Gosálbez, L. Jiménez, D. Boer, Design of environmentally conscious absorption cooling systems via multi-objective optimization and life cycle assessment, Applied Energy, 86 (2009) 1712-1722.

[51] A. Al-Zahrani, J. Orfi, Z. Al-Suhaibani, B. Salim, H. Al-Ansary, Thermodynamic Analysis of a Reverse Osmosis Desalination Unit with Energy Recovery System, Procedia Engineering, 33 (2012) 404-414.

[52] A. Ahmadi, M. El Haj Assad, D.H. Jamali, R. Kumar, Z.X. Li, T. Salameh, M. Al-Shabi, M.A. Ehyaei, Applications of geothermal organic Rankine Cycle for electricity production, Journal of Cleaner Production, 274 (2020) 122950.

[53] E. Ghasemian, M.A. Ehyaei, Evaluation and optimization of organic Rankine cycle (ORC) with algorithms NSGA-II, MOPSO, and MOEA for eight coolant fluids, International Journal of Energy and Environmental Engineering, 9 (2018) 39-57.

[54] M.A. Ehyaei, A. Ahmadi, M.A. Rosen, A. Davarpanah, Thermodynamic Optimization of a Geothermal Power Plant with a Genetic Algorithm in Two Stages, Processes, 8 (2020) 1277.

[55] A. Bejan, Advanced engineering thermodynamics, John Wiley \& Sons, 2016.

[56] G. Demirkaya, R.V. Padilla, A. Fontalvo, M. Lake, Y.Y. Lim, Thermal and Exergetic Analysis of the Goswami Cycle Integrated with Mid-Grade Heat Sources, Entropy, 19 (2017) 416.

[57] F. Xu, D.Y. Goswami, S.S. Bhagwat, A combined power/cooling cycle, Energy, 25 (2000) 233-246.

[58] D.Y. Goswami, F. Xu, Analysis of a new thermodynamic cycle for combined power and cooling using low and mid temperature solar collectors, (1999).

[59] A. Naseri, M. Bidi, M.H. Ahmadi, Thermodynamic and exergy analysis of a hydrogen and permeate water production process by a solar-driven transcritical $\mathrm{CO} 2$ power cycle with liquefied natural gas heat sink, Renewable Energy, 113 (2017) 1215-1228.

[60] H.T. El-Dessouky, H.M. Ettouney, Fundamentals of salt water desalination, Elsevier, 2002.

[61] A. Lazzaretto, G. Tsatsaronis, SPECO: a systematic and general methodology for calculating efficiencies and costs in thermal systems, Energy, 31 (2006) 1257-1289.

[62] A. Bejan, G. Tsatsaronis, M. Moran, Thermal Design and Optimization John Wiley and Sons, Inc. New York, (1996).

[63] E. Bellos, S. Pavlovic, V. Stefanovic, C. Tzivanidis, B.B. Nakomcic-Smaradgakis, Parametric analysis and yearly performance of a trigeneration system driven by solar-dish collectors, International Journal of Energy Research, 43 (2019) 1534-1546.

[64] C. Tzivanidis, E. Bellos, K.A. Antonopoulos, Energetic and financial investigation of a stand-alone solarthermal Organic Rankine Cycle power plant, Energy conversion and management, 126 (2016) 421-433.

[65] H. Nami, I.S. Ertesvåg, R. Agromayor, L. Riboldi, L.O. Nord, Gas turbine exhaust gas heat recovery by organic Rankine cycles (ORC) for offshore combined heat and power applications-Energy and exergy analysis, Energy, 165 (2018) 1060-1071.

[66] M. Mishra, P.K. Das, S. Sarangi, Optimum design of crossflow plate-fin heat exchangers through genetic algorithm, (2004). 
[67] A. Ahmadi, D.H. Jamali, M.A. Ehyaei, M.E.H. Assad, Energy, exergy, economic and exergoenvironmental analyses of gas and air bottoming cycles for production of electricity and hydrogen with gas reformer, Journal of Cleaner Production, 259 (2020) 120915.

[68] https://www.flinnsci.com/sodium-chloride-laboratory-grade-500-g/s0063/ [Access 03.06.2020], in, 2020.

[69] H. Nami, E. Akrami, Analysis of a gas turbine based hybrid system by utilizing energy, exergy and exergoeconomic methodologies for steam, power and hydrogen production, Energy Conversion and Management, 143 (2017) 326-337.

[70] J.C.E.P. Carlos Eymel Campos Rodrígueza, César Rodríguez Sotomontea, Marcio Lemea, Osvaldo J. Venturinia, Electo E. Silva Loraa, Vladimir Melián Cobasa, Daniel Marques dos Santosb, Fábio R. Lofrano Dottoc, Vernei Giallucad, Exergetic and economic analysis of Kalina cycle for low temperature geothermal sources in Brazil, in: The 25th international conference on efficiency, cost, optimization, simulation and environmental impact of energy systems, Perugia, Italy, 2012, pp. 1-13.

[71] P. Dorj, Thermoeconomic Analysis of a New Geothermal Utilization CHP Plant in Tsetserleg, in: Department of Mechanical and Industrial Engineering, Iceland, University of Iceland, 2005.

[72] A. Bejan, G. Tsatsaronis, M.J. Moran, Thermal design and optimization, John Wiley \& Sons, 1995.

[73] K. Bahlouli, R. Khoshbakhti Saray, N. Sarabchi, Parametric investigation and thermo-economic multiobjective optimization of an ammonia-water power/cooling cycle coupled with an $\mathrm{HCCl}$ (homogeneous charge compression ignition) engine, Energy, 86 (2015) 672-684.

[74] L.S. Vieira, J.L. Donatelli, M.E. Cruz, Exergoeconomic improvement of a complex cogeneration system integrated with a professional process simulator, Energy Conversion and Management, 50 (2009) 19551967.

[75] R. Turton, R.C. Bailie, W.B. Whiting, J.A. Shaeiwitz, Analysis, synthesis and design of chemical processes, Pearson Education, 2008.

[76] J.L. Silveira, C.E. Tuna, Thermoeconomic analysis method for optimization of combined heat and power systems. Part I, Progress in Energy and Combustion Science, 29 (2003) 479-485.

[77] M. Ameri, P. Ahmadi, A. Hamidi, Energy, exergy and exergoeconomic analysis of a steam power plant: A case study, International Journal of Energy Research, 33 (2009) 499-512.

[78] M.L. Koenraad F. Beckers, TimothyJ. Reber, Brian J. Anderson,Michal C. Moore, Jefferson W. Tester, Introducing geophires V1.0 software package for estimating levelized cost of eletricity and/or heat from enhanced geothermal systems, in: Thirty-EighthWorkshop on Geothermal Reservoir Engineering, Stanford University, Stanford, California, USA, 2012.

[79] Y. Du, L. Xie, J. Liu, Y. Wang, Y. Xu, S. Wang, Multi-objective optimization of reverse osmosis networks by lexicographic optimization and augmented epsilon constraint method, Desalination, 333 (2014) 66-81.

[80] Establishment of cost functions for construction of various types of public water services assets in Portugal, in, 2003.

[81] Sodium hypochlorite production plant of chlorination system chemical production plant alibaba.com/product-detail/Sodium-hypochlorite-production-plant-of-chlorination_60489161719 [Access 03.06.2020], in, 2020.

[82] L. Pierobon, T.-V. Nguyen, U. Larsen, F. Haglind, B. Elmegaard, Multi-objective optimization of organic Rankine cycles for waste heat recovery: Application in an offshore platform, Energy, 58 (2013) 538-549.

[83] S.J. Zarrouk, M.H. Purnanto, Geothermal steam-water separators: Design overview, Geothermics, 53 (2015) 236-254.

[84] T. Shafer, Calculating Inflation Factors for Cost Estimates, in, City of Lincoln Transportation and Utilities Project Delivery.

[85] Statista, Global inflation rate compared to previous year, in.

[86] S. Edalati, M. Ameri, M. Iranmanesh, H. Tarmahi, M. Gholampour, Technical and economic assessments of grid-connected photovoltaic power plants: Iran case study, Energy, 114 (2016) 923-934. 
[87] T.A. Ratlamwala, I. Dincer, M.A. Gadalla, Comparative environmental impact and sustainability assessments of hydrogen and cooling production systems, in: Causes, Impacts and Solutions to Global Warming, Springer, 2013, pp. 389-408.

[88] T.A. Ratlamwala, I. Dincer, B.V. Reddy, Exergetic and Environmental Impact Assessment of an Integrated System for Utilization of Excess Power from Thermal Power Plant, in: Causes, Impacts and Solutions to Global Warming, Springer, 2013, pp. 803-824.

[89] A. Midilli, I. Dincer, Development of some exergetic parameters for PEM fuel cells for measuring environmental impact and sustainability, International Journal of Hydrogen Energy, 34 (2009) 3858-3872. [90] J.S. David Birchby, Sally Whiting,, M. Vedrenne, Air Quality damage cost update 2019, in, 2019.

[91] S. Karkour, Y. Ichisugi, A. Abeynayaka, N. Itsubo, External-Cost Estimation of Electricity Generation in G20 Countries: Case Study Using a Global Life-Cycle Impact-Assessment Method, Sustainability, 12 (2020) 2002.

[92] Combined Heat and Power (CHP) Developers Guides in, United Kingdom Government Department of Energy \& Climate Change 2009.

[93] H.I. Emara, Nutrient salts, inorganic and organic carbon contents in the waters of the Persian Gulf and the Gulf of Oman, Journal of the Persian Gulf, 1 (2010) 33-44.

[94] FILMTEC ${ }^{\text {TM }}$ Membranes How to Evaluate the Active Membrane Area of Seawater Reverse Osmosis Elements, dupont.com/content/dam/dupont/amer/us/en/water-solutions/public/documents/en/45D01504-en.pdf [Access 03.06.2020] (2015). 